\title{
BANK MARKETING MANAGEMENT
}

\author{
Case: Sacombank group
}

\author{
LAHTI UNIVERSITY OF APPLIED \\ SCIENCES \\ Degree programme in Internaitonal \\ Business \\ Thesis \\ Autumn 2013 \\ Ly, Duong Hai \\ Mai, Thi Thu Trang
}


Lahti University of Applied Sciences

Degree Programme in International Business

LY, DUONGHAI Bank marketing management

MAI, THI THU TRANG

Case: Sacombank group

Bachelor's Thesis in Degree Programme in International Business 119 pages, 4 pages of appendices

Autumn 2013

ABSTRACT

The Banking and Finance Industry are among the most important service sectors in an economy. It is no doubt to say that banking is the backbone of the economy. The Vietnamese economy has lots of major changes since the "Doi Moi" 1986 reform in various sectors. Among of them is the banking service, which will continue to play important roles in the whole of the Vietnamese economy. In order to establish a healthy economy, maintaining and developing the banking sector is one of the essential responsibilities. Thanks to bank marketing management that provides various framework analyses and marketing strategies, banks can switch from the difficulties and threats into strengths and opportunities.

This thesis was written in the aim to assist the Sacombank group, which now has a strong position in the banking market in Vietnam, to find out the proper marketing strategy that can be used for bank marketing management. Therefore, the studies of internal, external analysis of the Vietnamese banking market, current marketing strategy in banking services are mentioned in this thesis.

The thesis uses deductive approach and qualitative method. In the theoretical part, data is obtained from a variety of sources, mainly published texts and other information from the internet. The authors' own observations and evaluations are also used in the empirical studies.

Finally, the thesis comes to conclude that the marketing plan in Sacombank accounts for a high portion of its success in winning customers. There are various marketing strategies that Sacombank group should consider carefully before making marketing decisions in every banking activity. 
Key words: Sacombank marketing strategy, service marketing, bank marketing 
$1 \quad$ INTRODUCTION 1

$1.1 \quad$ Background 1

1.2 Research objectives and questions 1

1.3 Research methodology and data collections 2

1.4 Scope and limitation: 4

1.5 Thesis structure: 5

2 SERVICE MARKETING MANAGMENT 6

$\begin{array}{lll}2.1 & \text { Service marketing }\end{array}$

2.1.1 Service marketing definition 6

$\begin{array}{lll}2.1 .2 & \text { Service's characteristics } & 10\end{array}$

$\begin{array}{lll}2.2 \text { Bank marketing } & 12\end{array}$

2.2.1 History of bank marketing in the world 12

2.2.2 The necessity of bank marketing 13

$\begin{array}{lll}2.3 & \text { Situation analysis } & 17\end{array}$

$\begin{array}{lll}2.3 .1 & 19\end{array}$

2.3.2 External Environment 22

$\begin{array}{lll}2.3 .3 & \text { SWOT analysis } & 26\end{array}$

$\begin{array}{lll}2.4 & \text { Marketing objectives } & 27\end{array}$

2.5 Segmentation, targeting and positioning 28

$\begin{array}{lll}2.5 .1 & \text { Segmentation } & 29\end{array}$

2.5.2 Target market 33

2.5.3 Positioning 35

2.6 Marketing mix 36

$\begin{array}{lll}\text { 2.5.2 Product strategies } & 37\end{array}$

2.5.3 Pricing strategies 38

2.5.4 Distribution strategy 41

2.5.5 Promotion strategies 42

2.5.6 Human Resource strategies 44

2.5.7 Process strategies 45

$\begin{array}{lll}2.5 .8 & \text { Physical evidence strategies } & 46\end{array}$

3 CASE: SACOMBANK'S SERVICE MARKETING PLAN 51 
3.1 Sacombank profile $\quad 51$

$\begin{array}{lll}3.2 & \text { Situation analysis } & 54\end{array}$

3.2.1 Internal environment 54

3.2.2 External environment 58

3.2.3 SWOT analysis $\quad 73$

3.3 Marketing objective $\quad 75$

3.4 Segmentation, target market and positioning 77

$\begin{array}{lll}3.4 .1 & \text { Segmentation } & 77\end{array}$

$\begin{array}{lll}3.4 .2 & \text { Target market } & 78\end{array}$

$\begin{array}{lll}\text { 3.4.3 Positioning } & 79\end{array}$

3.5 Marketing mix strategies $\quad 81$

3.5.1 Product: 82

3.5.2 Pricing policy 83

3.5.3 Distribution 86

3.5.4 Promotion $\quad 89$

3.5.5 Human resources 91

3.5.6 Process 93

4 CONCLUSIONS 96

$5 \quad$ REFERENCES 97

$\begin{array}{ll}\text { APPENDICES } & 105\end{array}$ 


\section{LIST OF FIGURES}

FIGURE 1. Qualitative and Quantitative methods (Quantitative and qualitative research 2011)

FIGURE 2. Deductive and Inductive research approaches (Quanlitative and Quantitative

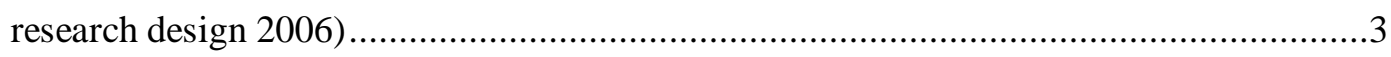

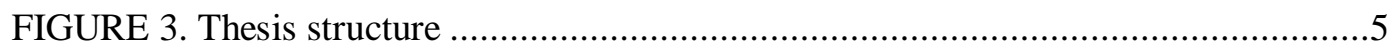

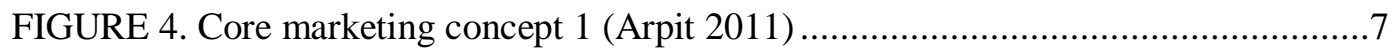

FIGURE 5. Growth in the service sector (the Maiden voyage of financial capitalism 2009)

FIGURE 6. Marketing plan (Wood, The Marketing Plan Handbook 2011, 64) ...............11

FIGURE 7.Five I's service (Lovelock \&Wright 2001, 5-7 ) ...........................................9

FIGURE 8. Bank marketing function (Uppal, Marketing of bank product 2009, 35-42) 15

FIGURE 9. Situation analysis (SWOT-analyse til besvær 2011) ...................................18

FIGURE 10. Situation analysis (Assess current position 2010) .....................................19

FIGURE 11. Porter's Generic Value Chain (Porter 2008, 13-17) .....................................20

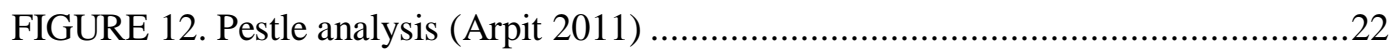

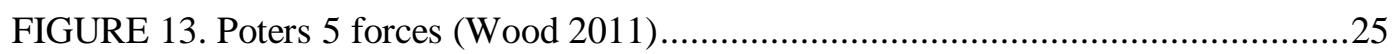

FIGURE 14. Target marketing process ( Gelder \& Woodcock 2003, 30-34) .................28

FIGURE 15. Market segmentation process (Four step market segmentation 2009) .........29

FIGURE 16. Consumer segmentation ( Steenburgh \& Avery 2010) ...............................31

FIGURE 17. VAL's framework (Yankelovich \& Meer 2006) .........................................32

FIGURE 18. Market segmentation strategies (Gupta 2005, 70-77) .................................34

FIGURE 19. Service-marketing mix (Service marketing mix 2012) ...............................36

FIGURE 20. Product's level (Kotler \& Armstrong 2010, 163-164) .................................37

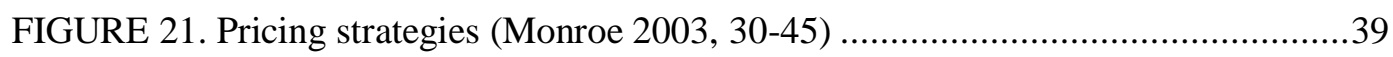

FIGURE 22. Pricing strategy process (Nguyen 2012, 24-27) .....................................40

FIGURE 23. Promotion strategy (Nguyen 2012, 42-44)............................................43

FIGURE 24. Organizational structure (Nguyen 2012, 47-49) .....................................45

FIGURE 25. Three component of the SOR model (Rober \& John 1982) ........................49

FIGURE 26. Sacombank Historic milestone (Tran 2012, 3) ..........................................53

FIGURE 27. Total asset of Sacombank (Tran 2012, 10) ..............................................55

FIGURE 28. Infrastructure of Sacombank (Tran 2012, 13) ............................................57

FIGURE 29. Vietnam's inflation rate (Inflation rate 2012) .......................................59

FIGURE 30. Vietnam import/export 2011 (Hoang 2011, 13-15) ................................64

FIGURE 31. Propotion of population living in urban area 2011 (Tran 2012, 17)...........66

FIGURE 32. Porter 5 forces (Staff 2012) ................................................................ 71

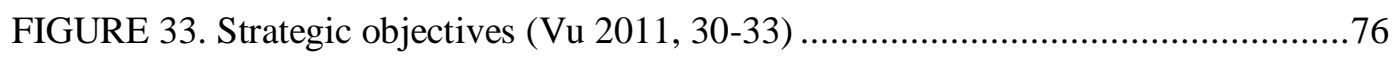


FIGURE 34. Positioning approach (Nguyen 2012, 32).

FIGURE 35. Marketing mix 7P (Nguyen 2012, 34) ................................................... 81

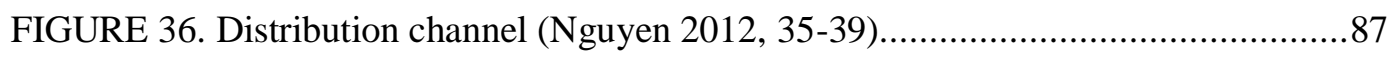




\section{LIST OF TABLES}

TABLE 1. Sacombank core value (Nguyen 2012, 4) ..............................................52

TABLE 2. Vietnam's statistics 2011 (Socio- economic statistics 2011 2011)................62

TABLE 3. The most attractive emerging markets 2010(Hoang 2011, 18)....................65

TABLE 4. Natural disasters in Vietnam 2008-2012 (Lawson 2013) ..............................69

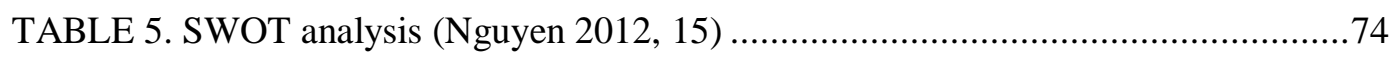

TABLE 6. Sacombank deposit rate (Tran 2012, 14) ...................................................84

TABLE 7. Sacombank interest rates $(\operatorname{Tran} 2012,16)$......................................................8

TABLE 8. Sacombank's programs (Tran 2012, 18) ...................................................90 
GLOSSARY

ATM

APEC

ASEAN

B2B

FDI

POS

SME

SACOMBANK

SOR

SWOT

VAT

VALS

WTO
Automated teller Machine

Asian-Pacific Economic Cooperation

Association of Southeast Asia Nations

Business to Business

Foreign Direct Investment

Points of Sale

Small and Medium enterprise

Saigon Thuong Tin Commercial Joint Stock Bank

Stimuli Organism Response

Strength, Weakness, Opportunity, Thread

Value Added Tax

Values, Attitudes and Lifestyles

World Trade Organization 


\section{INTRODUCTION}

\subsection{Background}

No one can deny the fact that banking services are now developing in Vietnam day by day, with the existence of hundreds of banks now in Vietnam. Although this is a small figure when comparing to other developed countries, it creates a fierce financial and banking market in Vietnam. Banks know that maintaining current customers is not sufficient. Expanding the market shares will be a tough challenge but brings back many competitive advantages in scale of services.

Bank marketing is understood as a system of organization and management of a bank to achieve maximum satisfaction of the needs of capital as well as other products and services of the bank for one or more groups of targeted customers. And those targets were selected through policies aimed at the ultimate goal with the highest profit maximization.

Nowadays, quantity and quality of bank products and services in the market is similar, there are no competitive differences among banks. Although marketing is not a new concept, it can be completely a strategic weapon which can help banks to overcome rivals in order to acquire more market share.

Therefore, it is said that bank marketing application in Sacombank always needs to be reformed quickly in order to meet customers' demand hence Sacombank will not lose customers and by contrast, the bank can also enhance its high competitive services in order to attract more customers.

\subsection{Research objectives and questions}

Research objectives of this thesis are to answer the following question:

How can managers improve the bank marketing service in Sacombank so that the bank overcomes the tough financial crisis difficulties and gains more benefits from customers? 
In order to achieve this objective, a list of necessary questions were studied and this thesis hopefully provides all needed information about the current situation of banking industry in Vietnam and Sacombank bank marketing management evaluations and solutions.

- What is service marketing concept?

- What is bank marketing concept?

- What is a bank marketing strategy in theory?

- What to analyse in bank marketing management?

- Bank marketing plan in practical situation?

\subsection{Research methodology and data collections}

There are two typical types of research method which are Quantitative and Qualitative. Quantitative generally can be seen as inductive while qualitative is seen as deductive. (Frankel \& Devers 2000, 251-261)

While statistical analysis and interpretation are objectives of Quantitative research, Qualitative research involves texts, images, data collected from interview and observation.

Both types of research aim at solving the problems but in different ways. Quantitative research often includes survey, sample, and questionnaires for collecting data which must be in numerical or countable value. This kind of research implements various mathematical and statistical methods to analyse data, then uses numerical value to sum up the whole study. The most important point of Quantitative research is the relationship between variable and participant of the research. (Neili 2007)

Quiet differently, Qualitative research processes data with text, pictures which are easier to observe. Qualitative is more useful than Quantitative in linking the relationship between researcher and participants. The most important factor of Qualitative is not variable but the case study which is the best tool to deal with the research problems. Qualitative firstly describes deeply the whole problem of the research and then is based on theoretical framework to resolve the problem. 


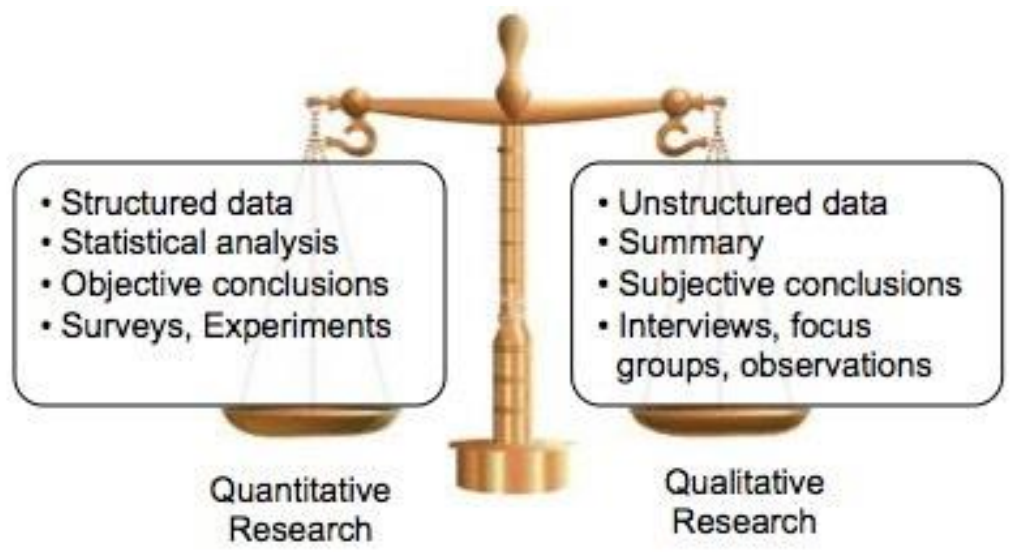

FIGURE 1. Qualitative and Quantitative methods (Quantitative and qualitative research 2011)

Basically, there are two kinds of research approach: Deductive and Inductive. It has been said that understanding these two types of research approach plays an important role in resolving the research problem. There are some different main points between Deductive and Inductive. Generally, Deductive research approach is associated with positivism paradigm while in the other hand, Inductive research approach follows the interpretivism (Crowther \& Lancaster 2009, 74-75). That means the deductive approach reaches the specific situation based on the general idea whereas Inductive approach follows up the specific idea before hypothesing the situation.

In terms of means, Deductive methodology allows the researcher to establish a hypothesis from the theory while Inductive methodology moves from specific observation to wider generalization and theories, as a "bottom- up" approach.

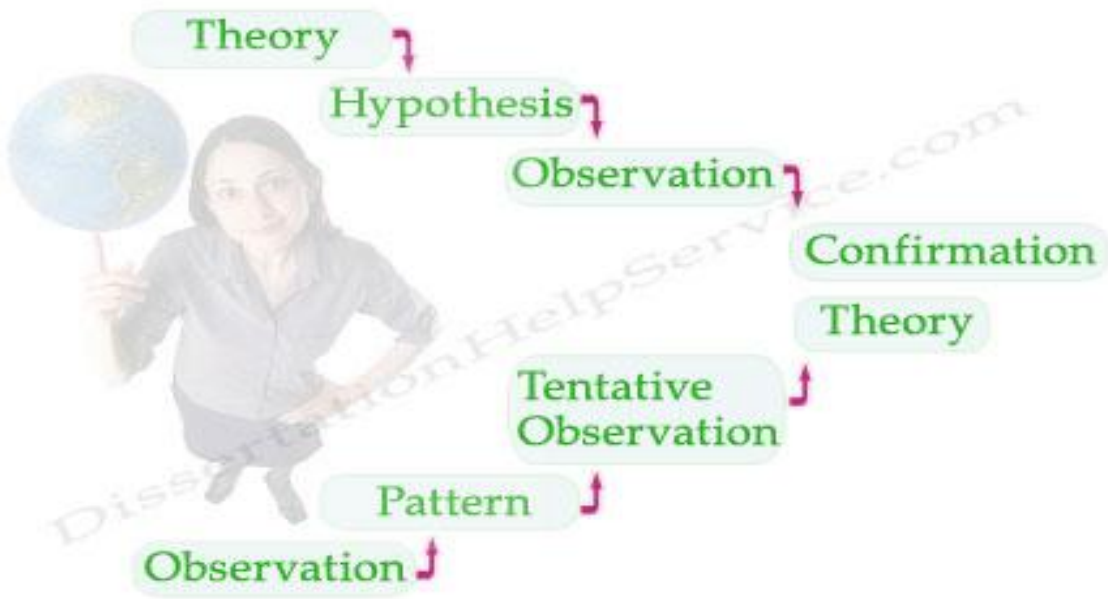

FIGURE 2. Deductive and Inductive research approaches (Quanlitative and Quantitative research design 2006) 
This thesis uses the qualitative and deductive method.

The fact is that all the data is based on the authors' observations, bank's personnel interview as primary source. The secondary source is from books, articles, journals and the company's annual report. In addition, Qualitative method processes with the non numeric information which is mainly acquired from interview, observation while quantitative method processes with the easily gathered information. Therefore, Qualitative research was used to resolve the problem.

The authors take advantage of real observation while doing the practical training in the case company and the logical thinking is based on the data collections to suggest solutions and predict the case company's situation in the future. Therefore, deductive method should be utilised.

\subsection{Scope and limitation:}

This thesis is written based on the authors' practical training program in Sacombank. By analyzing the current situation of the financial market in general and Sacombank in detail, the authors have studied essential knowledge in the banking situation before finding marketing solutions. Although there remains a certain amount of criteria to evaluate in the banking market, including the size, features, services, customers and local characteristics, the thesis targets two objectives:

- Bank marketing strategies at current situation analysis

- What to be enhanced in bank marketing strategies.

Inside the bank marketing strategy, bank marketing mix 7Ps accounts for the most essential strategies which consist of a variety of service strategies in order to create the value for the customers and capture benefits from them.

However, Sacombank's banking service is a broad area and its special marketing features are exchange rates and gold price fluctuations from day to day. Finding a right strategy for the bank marketing management system is really a big challenge for the thesis written at Bachelor level. The authors hope that thorough data and 
updated reports collection can provide a most updated and detailed solutions for the ever-changing banking market.

\subsection{Thesis structure:}

The thesis consists of four chapters as illustrated by the figure below:

\section{INTRODUCTION}

Background and thesis research approach methodology.

\section{SERVICE MARKETING MANAGMENT}

Service, bank marketing concepts and management

\section{CASE COMPANY}

Sacombank situation analysis and marketing mix

\section{CONCLUSION}

Bank marketing in practical situation conclusion

FIGURE 3. Thesis structure

The first chapter "introduction" includes the thesis background, research objectives and methodology.

The second chapter explains the theoretical framework to approach service marketing management by defining the service marketing concepts and analysing the service marketing process, also the marketing mix strategy 7Ps.

The case company is listed in the third chapter which covers Sacombank profile and the detailed approach of bank marketing in practical situation. This chapter is comprised of current marketing strategies in Sacombank as well as some suggested marketing strategies that may be useful for the development of the bank in the future. The conclusion chapter goes to summarize about what has been done in this thesis and the authors' own evaluations. 


\section{SERVICE MARKETING MANAGMENT}

This chapter will cover all the main analysis of marketing management. The first part is about giving some basic definition of marketing, service, service marketing plan. The second one is about focusing on the detail marketing plan in theoretical approach which is comprised of situation analysis; marketing objectives; segmentation, targeting, positioning and marketing mix.

\subsection{Service marketing}

Service marketing concept can be understood generally by combinating the marketing idea and service idea below. Moreover, it is necessary to capture the idea of a service marketing plan and service's characteristics.

\subsubsection{Service marketing definition}

\section{Marketing definition}

According to Philip Kotler, (P. Kotler 2010, 7) marketing is understood as follows:

"Marketing is a societal process by which individual and group obtain what they need and want through creating, offering and exchanging products and services of value freely with the other."(Social definition)

According to American Marketing Association definition: "Marketing is the process of planning, executing the conception, pricing, promotion and distribution of idea, goods, services to create exchanges that satisfy individual and organizational goal”. (P. Kotler 2010, 7)

Overall, there are various definitions of marketing simply but marketing can be seen as the delivery of customer satisfaction at a profit.

As the figure 4 shows, the procedure of marketing can be divided into several steps. The first step is to find out what customers need, want and require. 
This may vary between different customer segments. The next step is to create or develop products or services to satisfy possible customers'needs and wants.

Following that, companies should promote or communicate those benefits in order to promote purchase. This stage includes finding the correct marketing channel to meet customers' demand; making products Available at: the right place thus the exchange is facilitated. If that step is successful and customers show interests towards services, the next goal is to give price at right level so that customers are willing and able to buy products, as well as satisfy the customer's satisfaction with products' value and quality.

The last important step is to create long term relationships with customers by following their satisfaction level and by responding to that, for instance by rewarding loyal customers with small benefits. (Kotler \& Armstrong 2010, 2930).

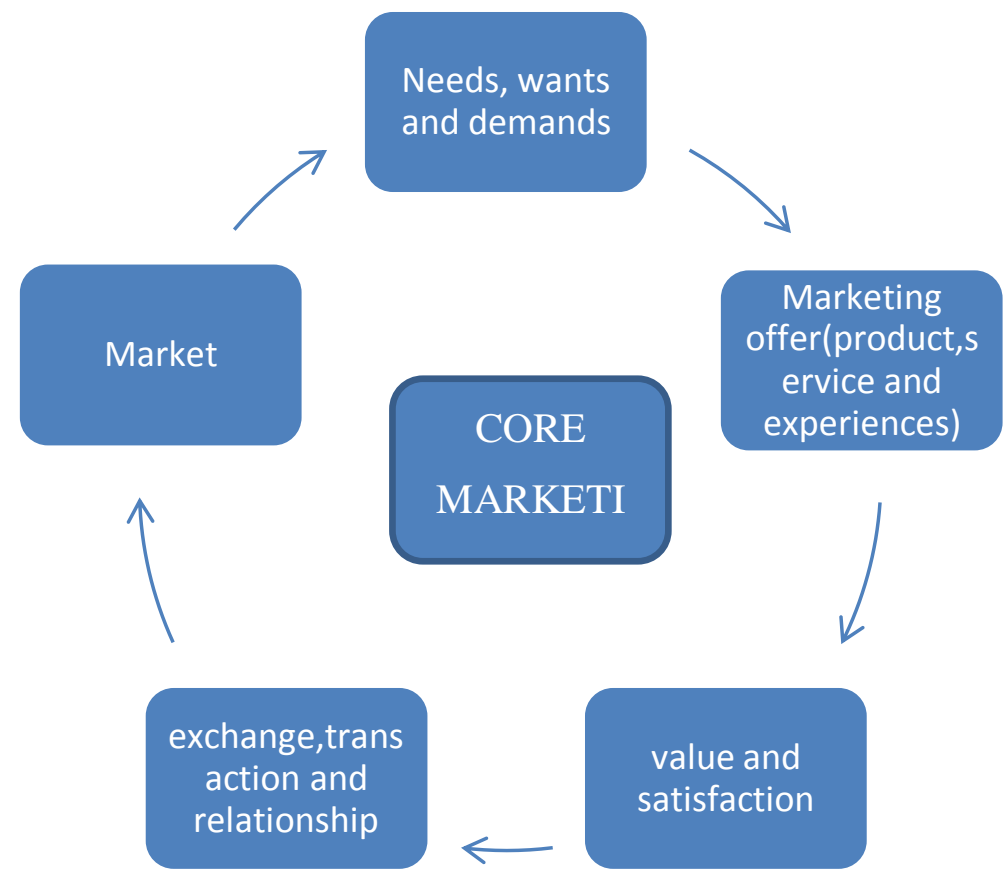

FIGURE 4 . Core marketing concept 1 (Arpit 2011)

\section{Service definition}


Services have traditionally been difficult to define. It can be described as the performance or act that creates benefits for customers by bringing a desired change on behalf of the recipient of services. ( Lovelock \& Wright 2001, 4-10)

Service makes up the bulk of today's economy. The service sectors accounts for most of the new job growth in developed countries. Figure 5 below has illustrated this truthfully.

\section{Growth in the Service Economy}

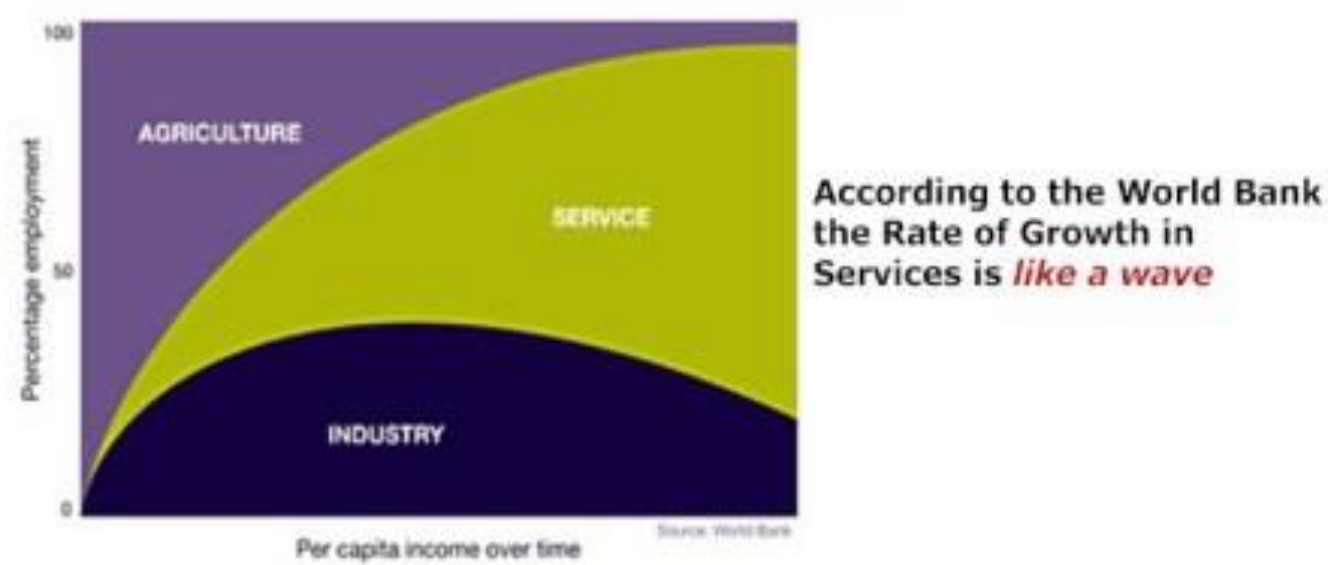

FIGURE 5 . Growth in the service sector (the Maiden voyage of financial capitalism 2009)

As can be seen from the figure, the share of employment among agriculture, service and industry have changed dramatically. Service increasingly plays an important role in economic development. Since per capital income increases, service is likely to dominate employment as well.

There are various kinds of economic service such as education, financial services, entertainment, food service, hospitality industry, transport, health care, construction....which consist of many huge international corporations like airline, hotel chains, banking or even B2B services and variety of locally owned or small business like restaurants, laundries, taxi....

\section{Service marketing plan}

A marketing plan is a written document derived from the analysis of the market environment in which it sets out major strategic objectives with short-term and medium-term for companies, or for a specific product groups. After that, they 
determine necessary means to carry out these objectives and actions to perform, finally calculate income and expenses to help establishing funding policies ( Kotler \& Keller 2006, 10)

There are various views on how to create a marketing plan. According to Kotler (Kotler 2000, 169) , a marketing plan should contain a situation analysis, marketing objectives and goals, marketing strategy, marketing action plan and marketing control. Whereas, in Wood's opinion (Wood, The Marketing Plan Handbook 2011, 64), a marketing plan should also contain market environment analysis, marketing objective and strategies, marketing implementation, evaluation and control. The modified Wood model is utilized in figure below.

FIGURE 6 . Marketing plan (Wood, The Marketing Plan Handbook 2011, 64)

As the figure seven describes, in the beginning of a marketing plan, companies should at first make a situation analysis in which they can realize factors and forces that will affect company's ability in maintaining and improving its competitiveness in the market. It is important to understand the market environment in order to comprehend consumer's concerns, motivations along with adjusting to products according to customers' needs. Two levels of market research are internal and external environment that will help to identify strengths, weaknesses, opportunities and threates to business. (Roger 2012, 31).

The next step is to identify marketing objectives. Marketing objectives are shortterm targets that lead finally to the company's long-term goals. It is what you want through your marketing activities. There are several important factors when considering establish effective marketing objectives. Firstly, they should be 
specific, measurable, time bound, realistic and achievable. Secondly, they must have a close connection with marketing strategies, and be consistent with company's capability. (what is marketing 2011)

Following that is the market segmentation step. It can be seen as a key dynamic in interpreting and executing a logical perspective of strategic marketing planning. This step includes segmenting, targeting and positioning. Through this way, the company will divide market into sub- groups according to various similarities. This will help company to identify the segment which is best suited with company's supply. (Middleton 2009, 99-101)

Finally is setting marketing strategies. After having a depth understanding of market environment, particularly customers and competitors, the company must set the marketing strategies with various marketing tools. Usually, a company will use 4Ps or 7Ps marketing tools as a marketing mix strategy to help itself influence demands for its product. (Kotler \& Armstrong 2010, 76)

\subsubsection{Service's characteristics}

Obviously, services can be explained in terms of their key characteristics, called the "Five I's service". This will be showed in the below figure. 


\section{Intangibility}

\section{Perishability}

\section{Inseparability}

\section{Inconsistency}

\section{Involvement}

FIGURE 7 . Five I's service ( Lovelock \& Wright 2001, 5-7)

As the figure clarifies, services are described as performances or acts while products are seen as physical objectives or devices. Services can not be touched, smelled or looked at. Therefore, there is no transported or storaged needs.

Services also can not be stored like products to be sold in the future because the producing and consuming of services happen at the same time.They are as performances that customers can enjoy, thus there are no inventories for services.

Services are inseparable because service providers must intently generate and distribute services to customer although service deliveries can be automatic. Service providers must also carefully prepare a service by assigning resources, systems and keep an eye on the delivery process. Additionally, customers are also involved in the production process as well. Normally, customers can help in creating services or either serving themselves in settings such as hospitals, hair salons....

Services are diversified nowaday. Each service has its own unique and is different from others. It can not be overlapped with the same location, same time of generation and consumption. As had been said above, service is inseparable. Customer is also the part of service process- the critical involvement of customers 
in services sector. It can be seen as one of the most important characteristics in services. Delivery of a service is quite difficult because it has different distribution channels. Unlike many other kind of business, Service business may either use electronic channels or combine the service factory and point of consumption at the single location. All of these service characteristics will be clearly analyzed in banking's essence as well. ( Lovelock \& Wright 2001, 5-7)

In conclusion, service marketing is quite different from other business due to its nature characters. Service marketing is the adaption of theory system to service market which including the process of procurement, learning, assessment and satisfying needs of the target market. They are done by providing a system of strategies, measures in the whole process of service supplying and consumption. Marketing is maintained in a dynamic interplay between services and consumers' demands and activities of competitors on the basis of balancing of interests among businesses, consumers and society.

\subsection{Bank marketing}

\subsubsection{History of bank marketing in the world}

Previously, banks were merely seen as the "keeping money safe." When conducting banking transactions, customers always feel annoying because of having to wait so much time.

While many other companies had been applying marketing strategies and being more successful, banks' executives were still intoxicated with their own operations, regardless of customers' needs as well as society demands. However, when the business environment changes, increasingly fierce competition in banking activities had made banks' administrators be interested in marketing. By the 60 s of the 20th century, it began to infiltrate marketing banking sector. In the U.S, the 60s was a period in the development of marketing retail banking operations. In Europe, it was not until the ' 70 s that marketing became the subject which was widely discussed in the Bank of England. (Uppal, marketing of bank product- emerging challenges and strategies 2009, 35-42) 
However, from the first time, the study of marketing had not had the right and sufficient vision already. Research marketing has undergone many stages that could improve gradually. At first, bank administrators learned and studied responses of customers and then gradually improved procedures, locations, time and quality of services. In addition to attracting customers, banks have begun to set out policies of customer's satisfaction with friendly attitude, friendly atmosphere. In particular, bank managers often research to make products in accordance with customers' tastes.

Thus, in a long time bank marketing has not been focused dramatically which limited the effectiveness of the banking business. However, as soon as bank managers have seen the importance of marketing, its perspective is increasingly more completed. Marketing became one of the most essential factors that bringing succeed to banks.

\subsubsection{The necessity of bank marketing}

\section{Concept of bank marketing}

Giving a precise concept of bank marketing is not easy because nowadays there are so many concepts of bank marketing.

Bank marketing can be understood as a system of banking strategies impacting on the entire process of providing banking services in the best way which will satisfy needs of target customers. Bank marketing is maintained in a vital interaction between products, services with customers' demands and activities of competitors on the basis of balance benefits among banks, customers and society.

(Shodhganga 2009, 1-12)

\section{Marketing role in banks}

- Marketing participates in solving fundamental economic problems of the banking business.

A commercial bank is organized in order to trade currency on financial markets. It performs many operations at home and abroad with basic trading functions. At the same time, banks are key tools in the implementation and delivery of funds to provide financial services to the economy ergo. Banks are seen as one of the most 
important organizations in financial economies. However, like other kinds of business, banks must also select and resolve basic economic problems of business activities with the active support of marketing. (Adillawa 2011)

- Marketing managers can provide better resolution determining types of products and services that banks provide to the market's needs through activities such as gathering information, researching customers' demands, learning products' competitors, researching products' using of individuals and enterprise customers..... This will help banks'managers to make decisions of which kind of products and services will be launched in the market. (Gupta 2012)

- Marketing contributes greatly to improve the quality of products and services, create prestigious image, and increase the competitiveness of banks. As marketing has many different methods to incorporate in the course of providing products and services of banks, such as facilities, engineering technology, staffs and customers. Especially, marketing also takes advantage of each element through strategic technology development techniques and strategies for human resource training and customer strategies. (Gupta 2012)

- Marketing managers help banks to dissolve the harmonious relationship between customer benefits, employees and banks. This is very important to maintain the relationship, and the motivation process business activities between banks and customers.

\section{Bank marketing functions}

Bank marketing has four following major functions which contribute significantly in banking development. Those functions can be interpreted in the figure below 


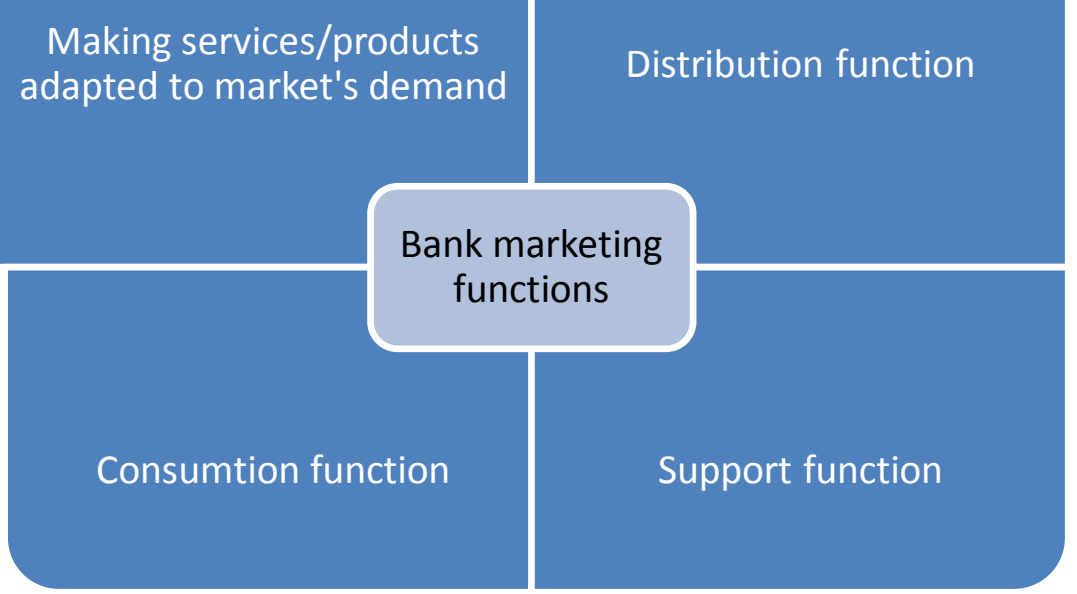

FIGURE 6. Bank marketing function (Uppal, Marketing of bank product 2009, 35-42)

As the figure emphasizes, the first function is making banking products and services adapted to market's demand.

Marketing researches the market in order to determine demands, desires and trends of the market as well as the change in customers' desired needs .From that, they can design new products and services which become more attractive and bring more utility to meet increasing needs of diverse markets. And at the same time, they can also createa competitive position. (Uppal, marketing of bank product- emerging challenges and strategies 2009, 35-42)

- Distribution Function

Distribution function of bank marketing covers the entire process of organizing banking products and services to selected clients. Its contents include learning and selecting potential customers, guiding and assisting customers in the selection and use of products/ services of banks, organizing activities at customer service outlets, researching to develop new distribution channels to meet customers'demands.

\section{- Consumption Function}

Products depend on many factors but the most important is the quality of products/ services and reasonable prices. This requires banks to improve their regular staff. 
This function also specifies that transactions must comply with: understanding customers, preparations of contact with customers, approaching customers, introduction of products/services using manual procedures. (Task and function of the marketing department of the bank 2012)

- Support function

Supporting the functionality of creating favorable conditions to perform three functions is also the crucial function of marketing in banking business. Activities supported include advertisemnets, propagandas and client conferences (Uppal, marketing of bank product- emerging challenges and strategies 2009, 35-42)

\section{Essence of Marketing in banking business}

- Characteristics of products

The Bank is organized for currency trading which is a special commodity. Products of banks are the services related to currency banks providing to customers. Therefore, Banks's products carry full natures of service and have the following main characteristics:

- Products and services of banks are invisible which are processes rather than specific objects. On the other hand, they are directly related to money, money is the main ingredient creating banking products .Generally, they are very sensitive to market information and customer psychologies. A small change in interest rates will also influence significantly on customer psychologies in the selection of banking products and services. ( Lovelock \& Wright 2001, 4-10)

The production and consumption occur simultaneously, for example with the direct involvement of customers in the course of providing products and services.

Products and services of banks are also made in different spaces, forming the heterogeneity of time, and implementation of conditional executions.

Products of banks are increasingly diversified, range of new products and services are launched drastically. Banking products bring high socialization so any little negligence in providing products (e.g. lack of cash payment, payment confusion, 
or faulty ATM system .... ) are capable of causing banks ' reputation . (Kotler \& Armstrong 2010, 269-270)

- Characteristics of clients

Client component is extremely important in the existence and development of banks. Customers have direct involvement not only in the process of providing banking products and services but also in the use, enjoyment of products and services. Therefore, customers'demands, requirements of products/services will be a decision factor in banking operations'success in terms of quantities, structures and qualities of products/services .Customers of banks are diversed, complex and contain many different segmentation criteria. Besides customers, demand for banking services is not uniform and is more volatile. ( Kotler \& Keller 2006, 269-275)

- Characteristics of competition

Competition in banking sector becomes drastic when the number of market participants increases and banking product portfolio expand continously. Competitive pressure acts as an impetus to create real growth banking products both current and in the future.trends among banks are expressed in the form of competitive marketing activities, technologies, and on the scale (for consolidation, merger or linking together to increase competitiveness).

\subsection{Situation analysis}

Marketing environment is not under control that companies must pay attention to the construction of their marketing strategies.Marketing environment is a set of active subjects and activities outside companies which not only affect the ability to direct the marketing department but also establish and maintain good relations with target customers.

The whole process of situation analysis can be summarized in the figure below 


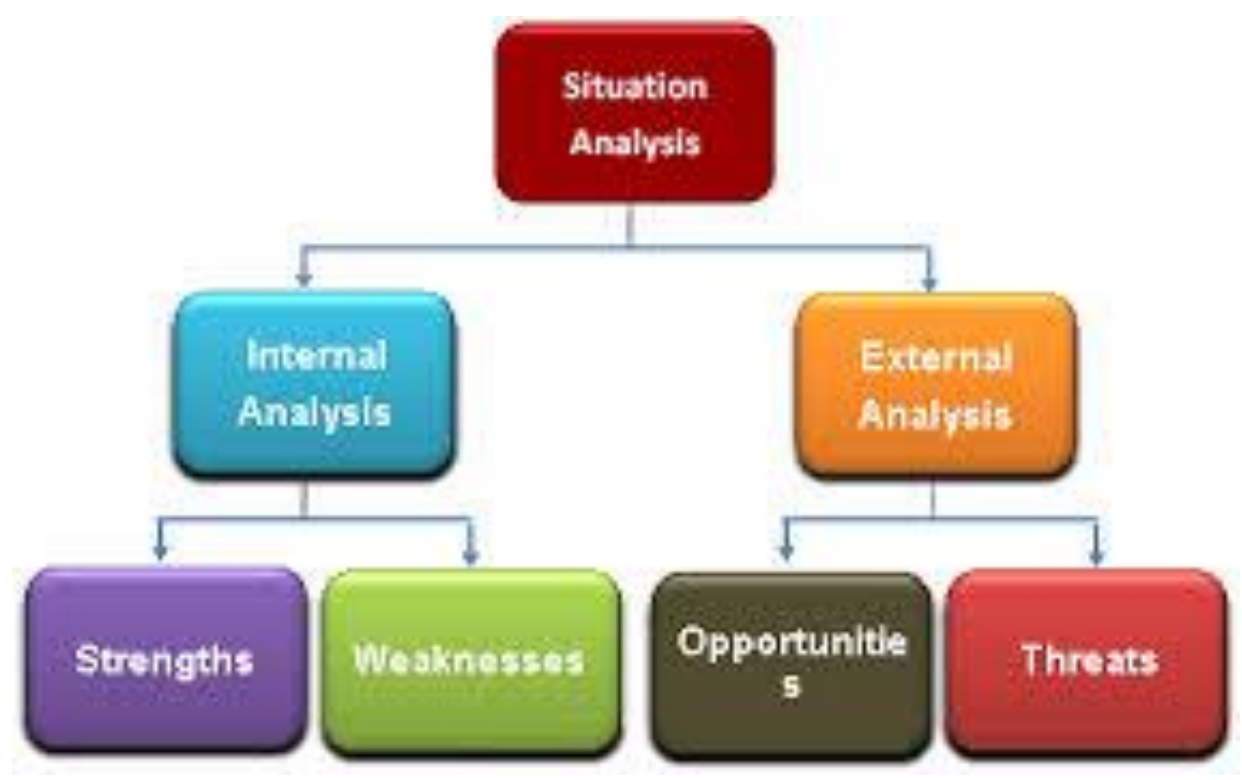

FIGURE 7. Situation analysis (SWOT-analyse til besvær 2011)

As Figure 9 shows, in situation analysis step, a company should analyze an organization's internal and external environment to understand the organization's capabilities, customers, and business environment. It consists of several methods of analysis: SWOT analysis, Porter five forces analysis, and Porter's value chains. It can be seen as a critical step in establishing a long-term relationship with customers, as a useful stage to indicate the organizational and product position of the company within the environment. From that, companies can comprehend their capabilities in the market through their summarization of situation analysis. ( Steenburgh \& Avery 2010).

The figure below will clarify factors that will indirectly and directly affect on business cooperation. Managers need to identify either strengths that they can rely on to compete or weaknesses that need to be corrected or minored as competitive factors. Besides, external factors such as political, environment, economic, social...will also become opportunities and threats for their business. 


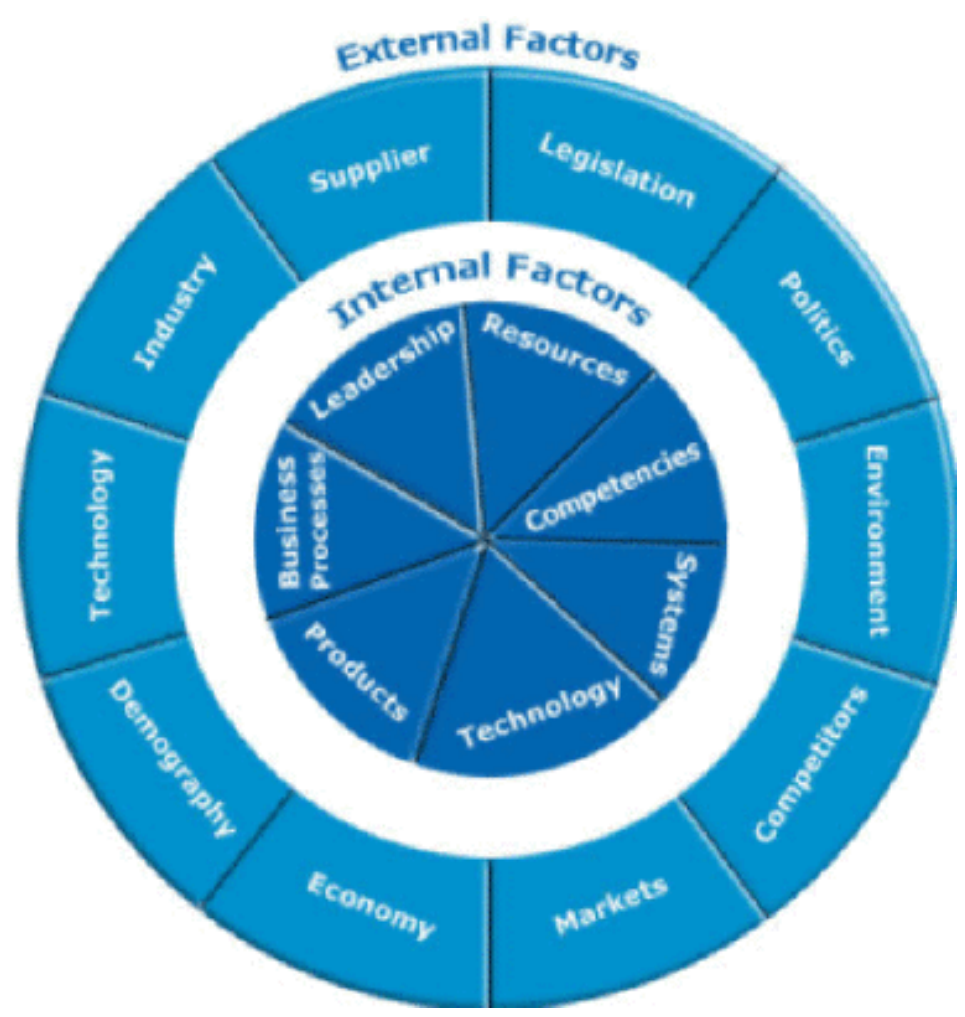

FIGURE 8. Situation analysis (Assess current position 2010)

As the figure represents, there are abundant internal and external factors that a company needs to analyze in the procurement of making a strategic marketing plan. Those will be interpreted clearly below.

\subsubsection{Internal environment}

Internal analysis evaluates company's mission, vision, financial capability, business relationship and key to success .Analyzing internal factors will help companies to identify strengths and weaknesses in order that they can take advantage of their strengths and improve their weaknesses, as a result, providing the best customer service. (Wood 2011, 30-31). Core competence of internal factors is helping companies to identify a unique set of lasting capabilities to achieve competitive advantages and add more value on innovation, efficiency, quality, and customer responsiveness. (Porter's value chain 2013) 


\section{Porter's Generic Value Chain}

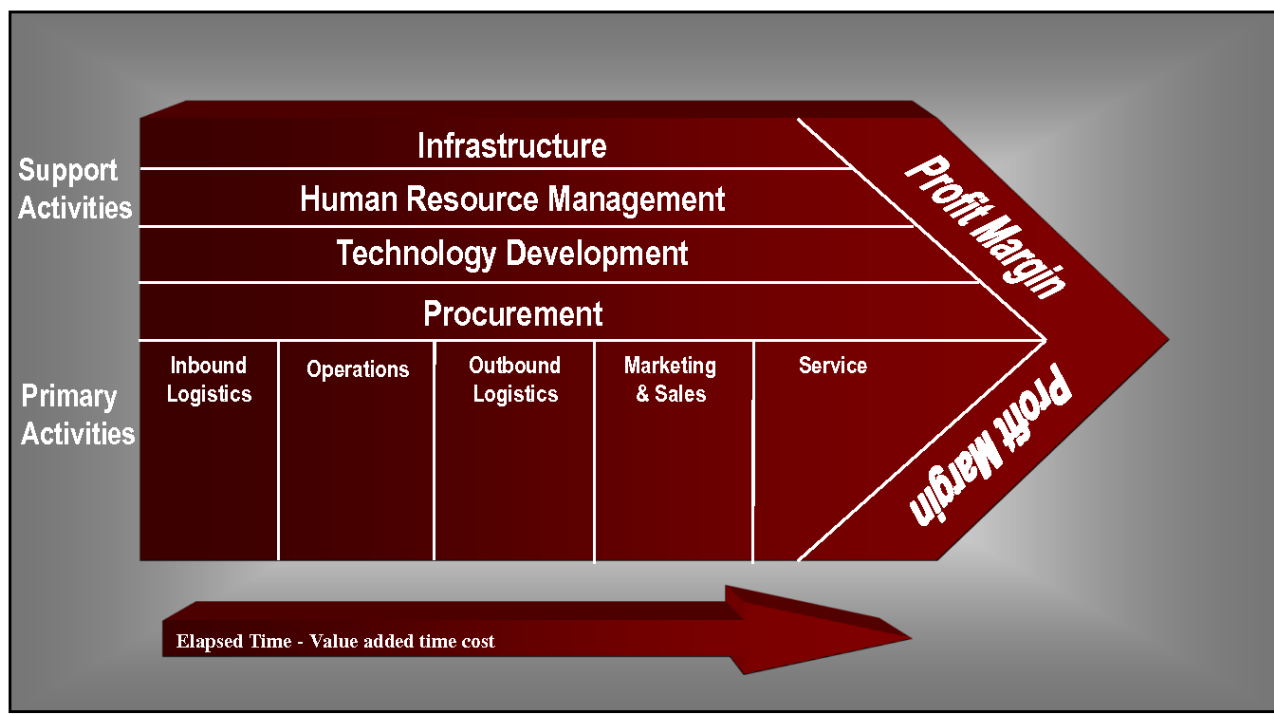

FIGURE 9. Porter's Generic Value Chain (Porter 2008, 13-17)

As can be seen from the figure above, the value chain makes a simplified illustration of all activities that a company should analyze to identify their weaknesses and strengths. Primary activities are those which directly involve in producing, selling, distributing or serving customers such as inbound logistics, operation, outbound logistics, marketing and sales. Support activities are those which will enable the performance of primary activities. Firm infrastructure will entirely support all values including quality of management, financial performance, strategy, organizational culture. Human resource is the way of recruiting, hiring, training, rewarding employees of an organization. And the last one is procurement in which a company needs to purchase and manage inputs used for operations as well as keeping a good relationship with suppliers and partners. (Porter 1985, 11-15)

Internal factors such as financial capability, technology, staff management, network, various departments in companies and the relationship among those departments will be analyzed below. (Singh 2012) 
Financial capability: Strong financial capacity will improve the competitive position of a company in the market. In order to implement a strategy successfully, it is important that a company should have a good financial capability. It means company must have the ability to resist risks. Besides, the investment capacity in branch network, IT infrastructure technology is also a critical requirement for business development while technology investment requires a huge amount of capital. Accordingly, the financial capacity of a company has a crucial role in their development.

Management skills and staff: The executive board of a company is very important; this is the determinant of failure or victory of a company. They have to regularly review the market to make decisions promptly and wisely. Not only the management staff is skilled but also employees are required sufficient knowledge because they are always companies' image. An omission or mistake of one employee will evaluate the quality of a company.

The network of companies: in order to sell more products and services to occupy large market share, companies often develop extensive branch network and ready to supply various products and services for customers.

The relationship among departments of companies: The organizational structure of companies plays an important role in the implementation of the marketing strategy. The organizational structure defines the roles and division of tasks specific to each department and employee. The division of companies to be organized and streamlined, and among departments, there must have a connection and support to each other.

Those factors will ensure companies in operations to meet market demand while improving the competitive position of companies in the market. This requires marketing department must have appropriate strategies to exploit these important internal resources. (Thomas 2001, 52) 


\subsubsection{External Environment}

External environment is the force on the larger social level, that affect the microenvironment, such as demographic, economic, natural, technical, political and cultural factors.

In this situation, PESTEL tool will be used to analyze external factors that affect bank-marketing operation. (Arpit 2011)

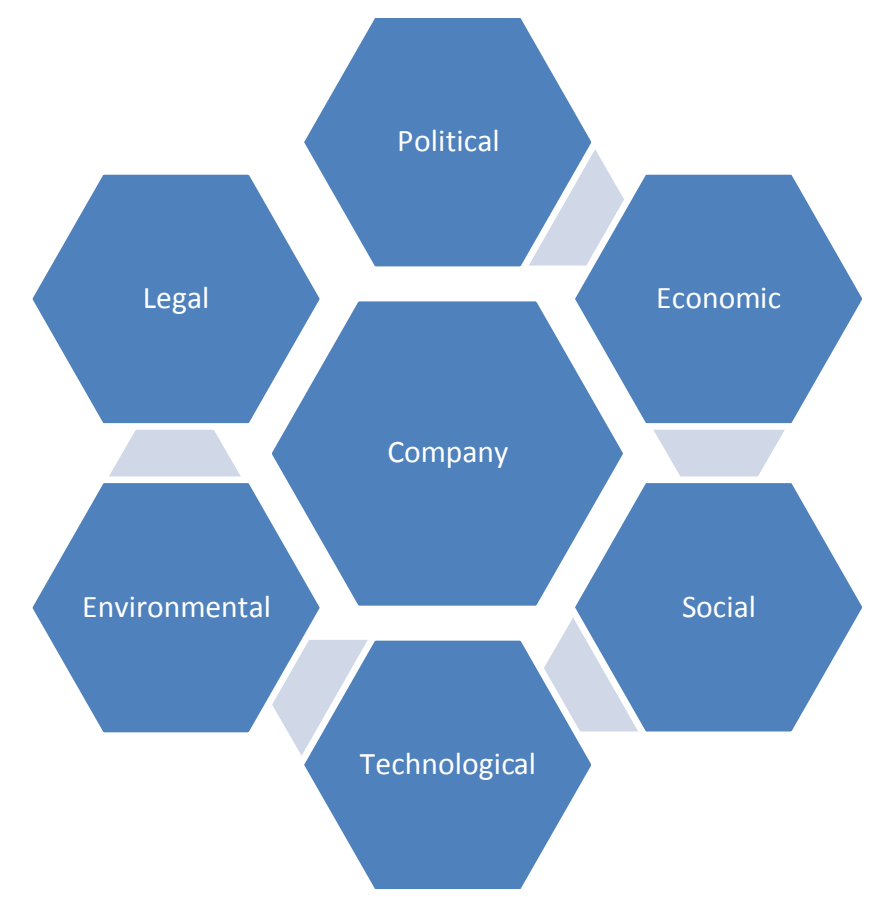

FIGURE 10. Pestel analysis (Arpit 2011)

As can be seen from the figure below, PESTEL analysis is a useful strategic tool which analyzes political, economic, social, technological, environmental, legal factors of the macro environment that companies have to take into consideration. As a consequence, they can fully understand the market growth or decline, business position, potential and direction for operations. According to that, they can take advantages to maximize opportunities and minimize threats to the organization (Pestel analysis 2010)

\section{Political and legal}

Political factors are basically what the government intervene the economy. Political area factors include tax policy, labor law, environmental law, tariff, trade restrictions.....Legal factors differentiate types of law that apply generally to 
business and specifically to those businesses that operate in the residential construction industry such as consumer law, employment law.... Those factors will affect how a company operates, its costs, and the demand for its products. (Pest market analysis tool 2010)

Company's operations are strictly supervised by law and the authority of the government. Activities of companies are usually adjusted very closely with the provisions of law. Therefore, changes in the regulatory policy of the government will affect directly and indirectly to companies in business and the product portfolio of companies. The change in government policies and regulations of the law has created opportunities for companies. Marketing department must regularly grasp the change of laws to regulate business activities in accordance with new regulations. In the current environment integration, marketing department must research to analyze and predict trends of environmental changes in law to know regulations of international institutions with related company's activities such as ASEAN,APEC, WTO... (Marketing therories pestel analysis 2009)

\section{Economic factors}

Economic factors have a significant impact on how an organization does business and how profitable they are. It includes all determinants of an economy and its condition. Economic factors are interest rates, the stage of the economic cycle, the balance of payments, fiscal policy and monetary. Because those factors are quite broad, it should be selected to identify specific impacts, which directly affect company's operations (Marketing therories pestel analysis 2009)

\section{Social factors}

Every country is different and each has a unique mindset. Social factors include demographics (population level, population growth, age, gender, income distribution....), living standard, lifestyle attitude, social mobility. Those factors concern the structure and nature of consumers of business market. Comprehending social factor will help companies to understand the market situation, realizing the growth or stagnation of exiting customer or emergence of 
new potential customer segmentation. Additionally, Research of trends can potentially reveal new business opportunities. (Wood 2011, 36)

\section{Technological factor}

It includes technological aspects such automation, technology incentives and the rate of change. Technological environment changes rapidly, the new technology not only creates new opportunities and market but also replaces the old one. Therefore, Companies must always keep close watch over new intention so that their products/services will not become out of date. That is why technological factors will affect the way companies marketing and manage their services/products in three distinct ways. Those are news way of producing, distributing and communicating in target market. Furthermore, technological factors will also affect costs, quality, and lead to innovation. (Kotler \& Armstrong 2010, 106-107)

The development of science and technology requires companies to innovate and improve product portfolio. It is the most powerful tool which brings wonders to company's operations, so that customer attitude to them depends on the technique used of companies. Therefore, marketing department must follow the development trend of technology in local, regional and global so that they can keep pace with market development and understand how consumers react to technological trends and how they utilize them for their benefit. (Pestel analysis : business environmental analysis 2008)\

\section{Environmental}

Environmental factors include climate change (rising sea level, flood, drought...) as well as energy consumption and waste disposal. Those factors will be affected partly of the location's country. Climate changes are factors that will alter the trade of every industry and the way customer react toward offerings which are launched in the market. Growing awareness of the potential impacts of climate change will affect how companies operate and the products they offer, both creating new markets and diminishing or destroying existing ones 
Besides PESTEL analysis, competition and market analysis are also the crucial factor that affects banking operation.

As the number of companies is increasing and all try to expand their product portfolio and raise company's orbi. The competition among companies is increasingly tough and fierce. Administrators have to focus on strengthening "competitiveness" and research competitors thoroughly. Keeping track of competitors will help companies in developing the product portfolio. In addition, competition in the market will be the driving force that helps companies quickly response to the market by creating new products diversity, richness which are better to meet customer needs. One competition analysis tool is Porter's five forces, a model that measures the profitability and attractiveness of a field of business.

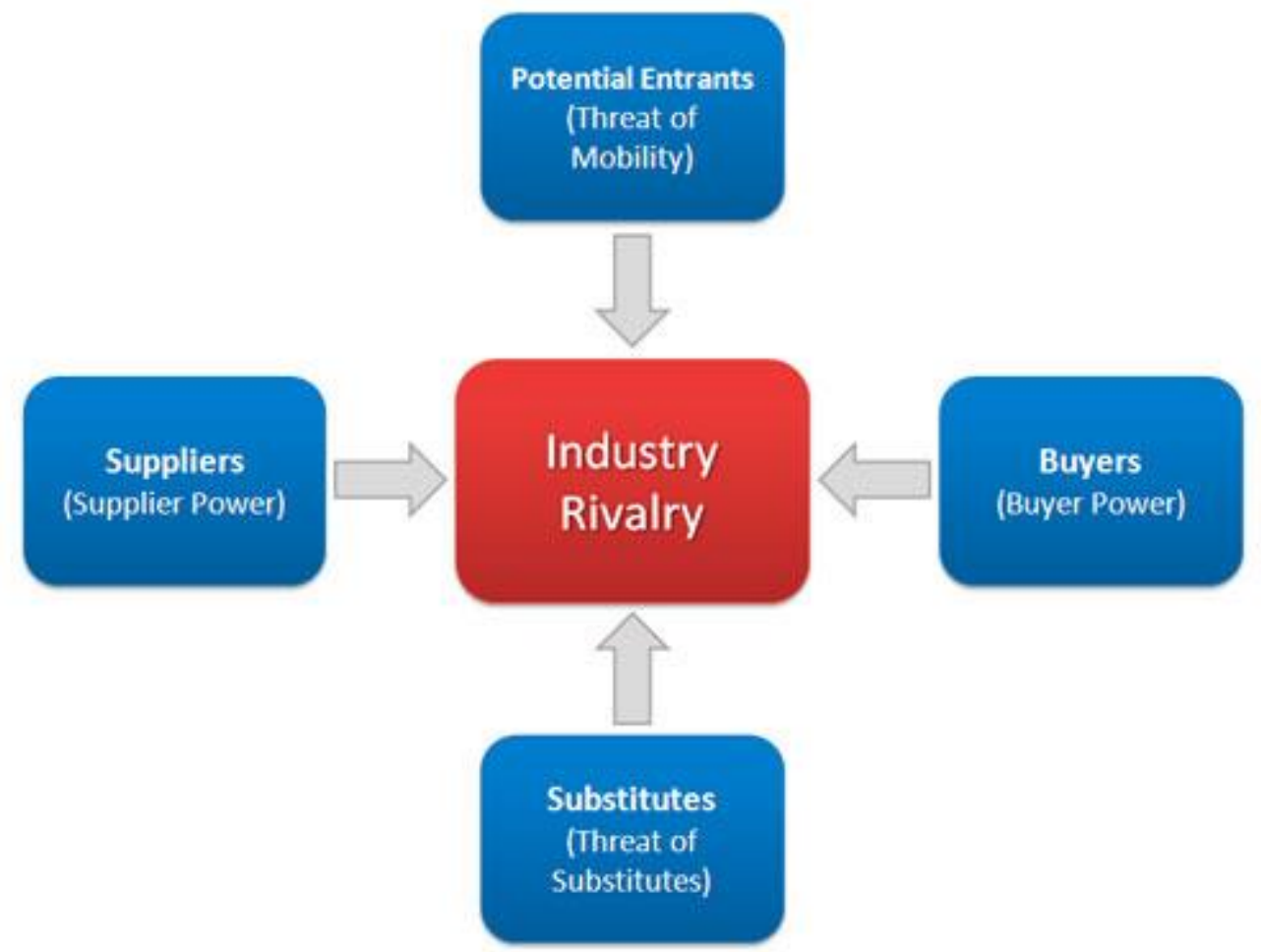

FIGURE 11. Porter 5 forces (Wood 2011)

The Porter models involves scanning the environment for threats from competitors and identifying problems early on to minimize threats imposed by competitors. It helps businesses to compare and analyze their profitability and position with the industry against indirect and direct competition. The threat of 
new entrants, which eventually will decline profitability for all companies in the industry because consumers have more variety to choose from, companies influence on buyer to purchase their product or how much the buyer depends on the product being produced by them... Threat of substitute product of services also affect bank's operation because almost companies having similar or the same product or service. Bargaining powers of suppliers is companies' dependence on resources which suppliers provide to create their product or services. On this side, companies will not have been affected so much because actually, companies trade currency and service relating to it. Therefore, the power of supplier is also the same power of customer who investigates their money in companies. In the center part, the rival among existing competitors will be the major determinant of the competitiveness of the industry. They will fight to dominant in the market and stay in business as well as maximize profit (Porter 2008)

\subsubsection{SWOT analysis}

There is no company which is always in a "perfect" condition. In order to create a flexible and creative marketing plan for company, marketing managers should thoroughly describe strengths, weaknesses as well as opportunities and threats of their companies. Hence, it is necessary to have a tool which can resolve these problems in a structured, analytical and integrated way. (Böhm 2009, 1)

"The SWOT analysis is one of the simplest and widely used of marketing analysis". ( Dibb \& Simkin 1996).

According to Dibb and Simin, The SWOT analysis provides an integrated approach which is comprised of the relationship between company and various environmental factors. The SWOT aims at evaluating a company internal strengths and its weaknesses as well as a company's external opportunities and threats before coming up to possible marketing strategy options. (Böhm 2009, 12)

In companies, the goal of analysing SWOT is to create the list of all internal and external strengths, weaknesses, opportunities and threats so that banking administrators can have a strategic marketing plan. The result of PESTEL analysis 
can be categorized as threats or opportunities in SWOT, whereas, internal factors can be seen as strengths and weaknesses of a company. (SWOT - internal and external analysis 2013).

However, what is an effective SWOT analysis?

Basically, an effective SWOT analysis should include a succinct, interesting and readable summary of the business's internal and external factors as well as the trends affecting upon it. Therefore, the information included in the SWOT analysis should be comprehensive, relevant and specific. ( Dibb \& Simkin 1996, 30-31)

Moreover, the concentration level of the SWOT analysis must be as much as possible. Companies may focus on the analysis at the customer segment level so that it gives the whole picture for what companies needs to achieve with its customers. In additions, strengths and weaknesses evaluation have to reflect the position of companies in relation to competitors. In additons, a strong point should be mentioned if it is really better than the compared aspects from competitors. ( Dibb \& Simkin 1996, 31-32)

\subsection{Marketing objectives}

It seems to be clear that we have all needed factors to analyse for the prospective marketing strategy. However, a company will never go to a right position unless it has a target destination. For the facts that analysis alone may not give marketers a sense of solution, marketing objectives alternatively give a destination where a company intends to be at some specific time in the future ( Ferrell \& Hartline 2010, 89).

James Quinn defined objectives as what thing to be achieved and when their results are to be accomplished while"how the result is achieved" is not mentioned. James stated that which products (or services) will be in which markets and certainly meet the customer's needs and wants. And also the relationship between products and markets are totally important things for marketing strategies in general and for each strategy in detail. (Quinn 1980, 192-193) 
Therefore, Objectives for pricing, distribution and promotion are at a lower level, and should not be considered as same as marketing objectives. They are part of marketing strategies which are used to achieve marketing objectives. In an effective approach, objectives should be measurable and quantifiable. This measurement may comprise of service satisfaction, brand value, market share, and percentage penetration of banking service. (Quinn 1980, 194-195)An example of measurable marketing objective can be mentioned "to provide the new debit service for urban customers in one month.

Marketing objectives must focus basically on companies financial objectives and then convert it into the related marketing measurements. In order to achieve those objectives, a marketing framework should be utilized.

2.5 Segmentation, targeting and positioning

\section{Target Marketing Process: Linking Customer Needs to Marketing Action}

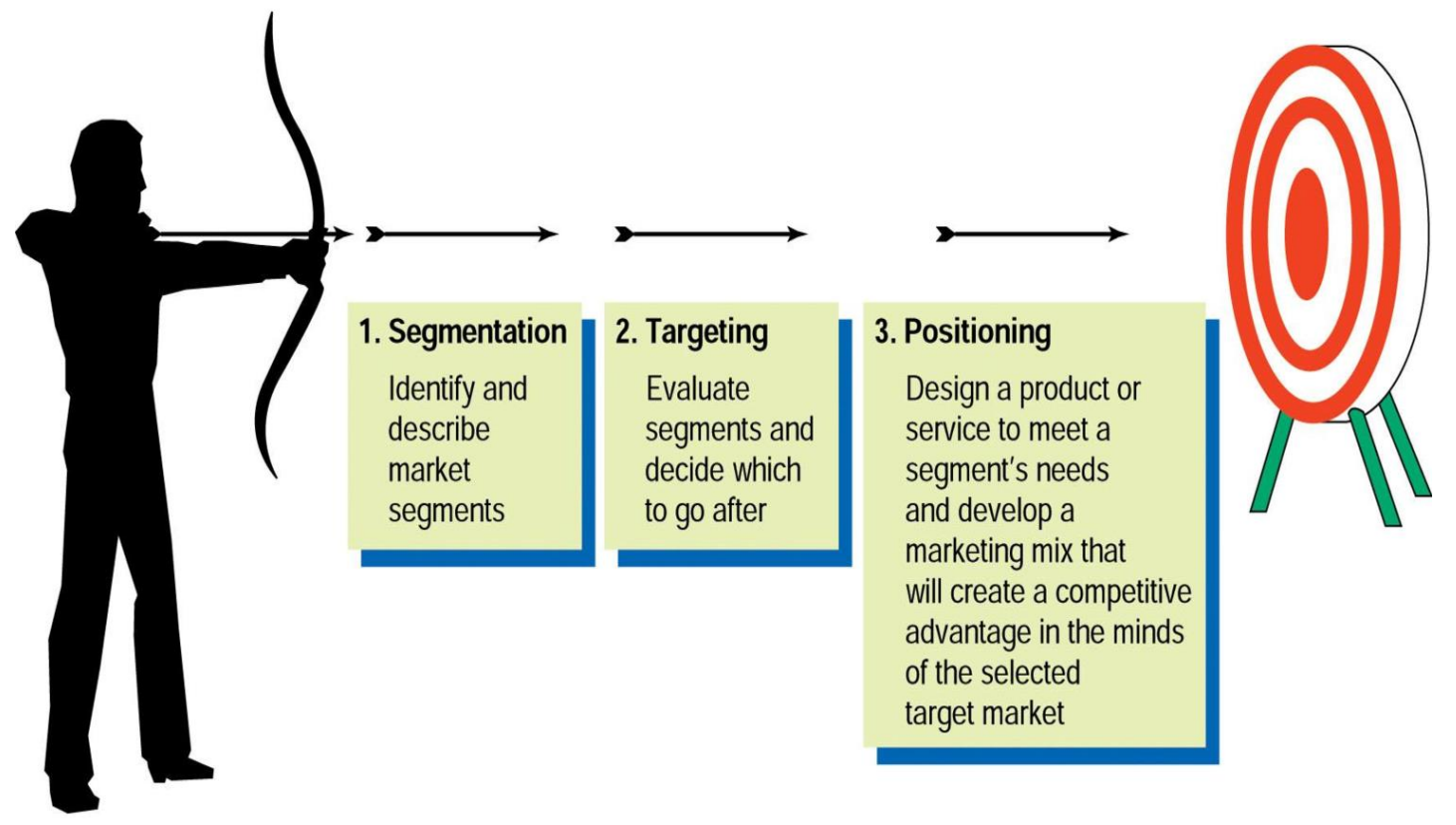

FIGURE 12. Target marketing process ( Gelder \& Woodcock 2003, 30-34)

It is said that delivering message through appropriate media is very important to reach the target market. Target marketing is known as identifying specific market segments within a larger audience and then "shooting" them with advertisement 
advertisement. (Neil 2012) This process is important in marketing and assists companies creating more value as well as reducing advertisement costs for their advertising investment. Wrong targeting process will lead company's marketing budget into uselessness. While the historical sales approach is trying to advertise to the as large buyer as possible, target marketing nowadays focuses on certain "targeted" markets which will help companies to save times and budget while it still creates value for their customers. Target marketing process includes three main factors:

\subsubsection{Segmentation}

Segmentation is a technique, which divides the market into distinct and consistent criteria that each segment can be selected as a target to be achieved through a separated policy of marketing ( Kotler \& Keller 2006, 25-29). The segment helps company to identify different needs of customers on the market, and specify the needs of customers that did not meet companys.In this case, Segmentation is considered as a fundamental matter - the heart of Marketing in highly competitive conditions. The process of segmenting is illustrated in the following figure
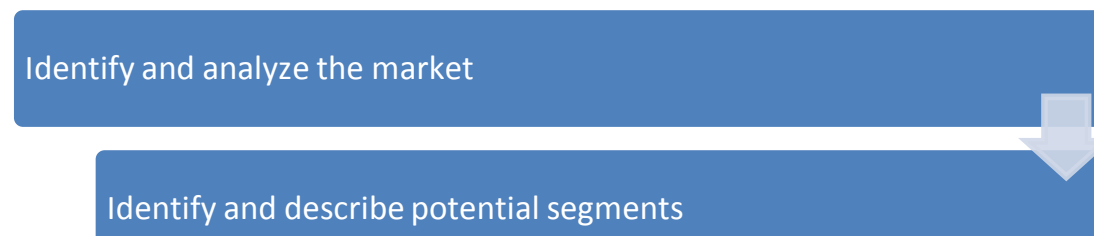

Analyze each segment

Evaluate market opportunities

Select target market

FIGURE 13. Market segmentation process (Four step market segmentation 2009)

As can be seen from the figure, the first segmenting step is to define and analyze the market which determines the market parameter within company mission and business definition. Next is to identify and describe potential segments, which will 
be based on the most useful dimensions in order to select potential segment markets. In addition, following is unifying customers into homogenous groups together with determining and developing characteristics of each group, analyzing the similarities that aggregate many members of a group as well as differentiations that separate segment from each other. The fourth step is to evaluate market opportunities in which customers, products/services and competitors will be analyzed. The customer's profile will help companies to identify segmented market and be suitable with company's capabilities, missions and objectives. The last one is to identify the target segments. All researchs, examinations and evaluations of market, potential segmented markets, and customers' profiles will help companies to determine segmented market. Once companies have completed those steps, it will be easy for them to have a strategic marketing plan and good preparation for campaign to compete in the market. (Four step market segmentation 2009)

An effective segmentation must be the process in which companies must be able to identify and measure each segment, reach customer well, the market must be substantial enough, customers in the selected segment must be responsive and characteristics of segments are comparatively steady over a long period.

Segmentation can be divided on three groups including segmenting consumer market, segmenting business market and segmenting international market based on variables' usefulness. Dimensions used to divide consumer markets into segments consist of both objective and subjective dimensions as noted in the figure below 


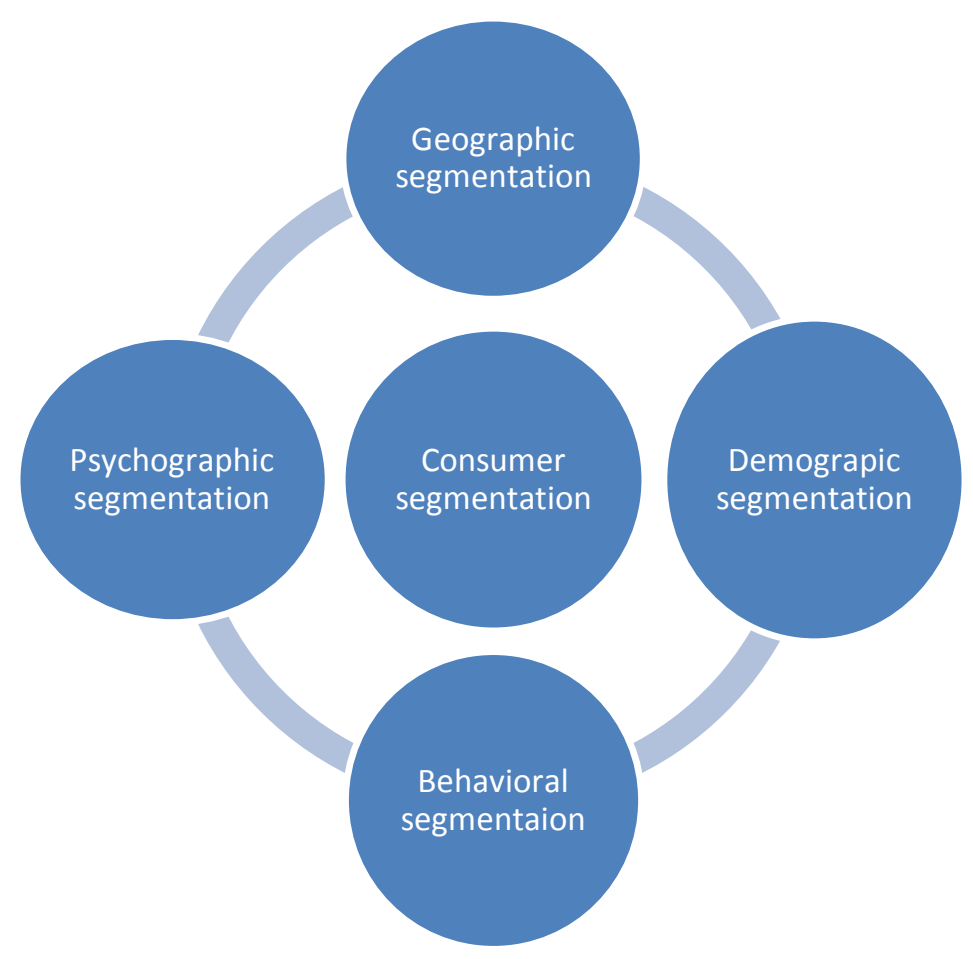

FIGURE 14. Consumer segmentation ( Steenburgh \& Avery 2010)

As the figure shows, geographic segmentation divides the market into various geographical units such as continent, country, state, province, city...that customer group resides. Demographics is focused on the characteristics of customers such as age,gender,education,family size, family cycle size,job,cutural background....Psychographics which refers to the social class, life styles or personal traits. Behavioral segmentation divides buyers into groups based on their knowldege,attitude and response to products/services such as occasions, user status, loyalty status...However, no variables is adequately comprehensive in identify segmented market. That is why combination of different variables is necessary in selecting target market. (Market analysis 2010)

Segmenting business market also divides customers into groups with similar needs and buying behaviors however this happens in a larger size .Demographic, geographic, behavioral, psychological descriptors are also specific dimensions that will be analyzed in business segmentation. Demographic segmenting will analyze the size of companies such as sales, number of employees, locations... and how customer will use the product, whereas geographic descriptors figure out the location of business in oversea or domestic markets. Psychological descriptors apply to the individual or groups who will have final decision on buying 
products/services. Finally yet importantly, behavioral segmenting usually is based on variables such as technology, usage, company related variables, purchase situation.... (Kotler \& Armstrong 2010, 7-12)

Segmenting international markets will be based on geographic locations, economic factors, political-legal factors and cultural factors. This kind of segmentation helps company to efficiently identify similarities among consumers across multiple oversea markets. (choice of consumer segmentation base 2012)

There are several of management tools that can be used to analyzed segmentation nowadays. VALS is proprietary research methodology used for psychographic market segmentation, which will classify customer into eight lifestyle segments. The focus is on consumer attitudes and values based on selforientation and resources. This will help company to tailor their products/services in order to appeal customer who have potential to buy it.this illustration of this methodology will be explained clearly in the figure below. (US framework and VALS types 2009)

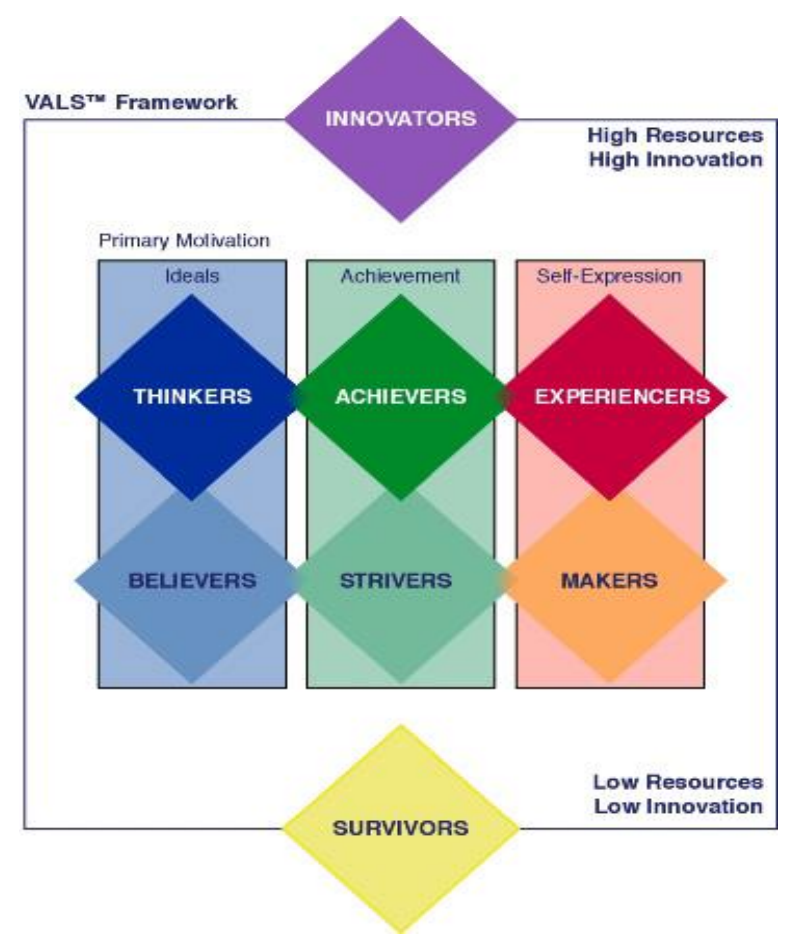

FIGURE 15. VAL's framework (Yankelovich \& Meer 2006)

As the figure shows, innovator is consumers who stand on the leading edge of change. They have highest income, high self-esteem and image plays an important 
role in their life as an expression of taste, personality and indpendence.while as thinkers are also high resource group, which are motivated by ideas and be matured, responsible as well as professional. The next one is believers who are in low resource group with modest income their life centerd on community,family. Achivers are the high resource group who are moderate,conventional,goal oriented and motivated by achivements.strivers are the low resource group who are also motivated by achivements but have fewer economic, social, and psychological resources than achivers.experineces are the high resource group who are energetic,impulsive,enthusiastic and motivated by self expression while as markers are opposited with them.and the last one is suvivors who are powerless,burdened,conservative and have the lowest income. (Yankelovich \& Meer 2006, 1-11)

The other segmentation tools are PRIZM and GLOBAL SCAN. Those are two popular systems of geolifestyle and geodemographic analysis. PRIZM classifies every American household into 66 unique segments organized into 14 different groups while GLOBAL SCAN identifies five global segments based on nationality, demographics, and values. (E learning session 2008)

Restoring to the case of banking segmentation, Criteria's for segmentations are diverse and plentiful. However, the authors will only concentrate on consumer segmentation or product/service segmentation, which have fully comprehensiveness to banking operations.

Companies can now rely on a number of key criteria's such as size, type of business, business quality, and customer relationship with companies.from that, they can make decision on how to conduct in enterprise segment in order to have an effective analysis. (Goldstein 2007)

\subsubsection{Target market}

Segmentation specifies the corresponding market opportunities for companies. After the market segment is completed, the next important choice is the target market to find the market those companies has stronger competitors. No one strategy wills suite all customer groups, thus the ability to develop specific 
strategies for target markets is very essential. There are three ordinary strategies for selecting targeted markets. The following figure will make an explanation about those. ( Lovelock \& Wright 2001)

\section{Market Segmentation Strategies}

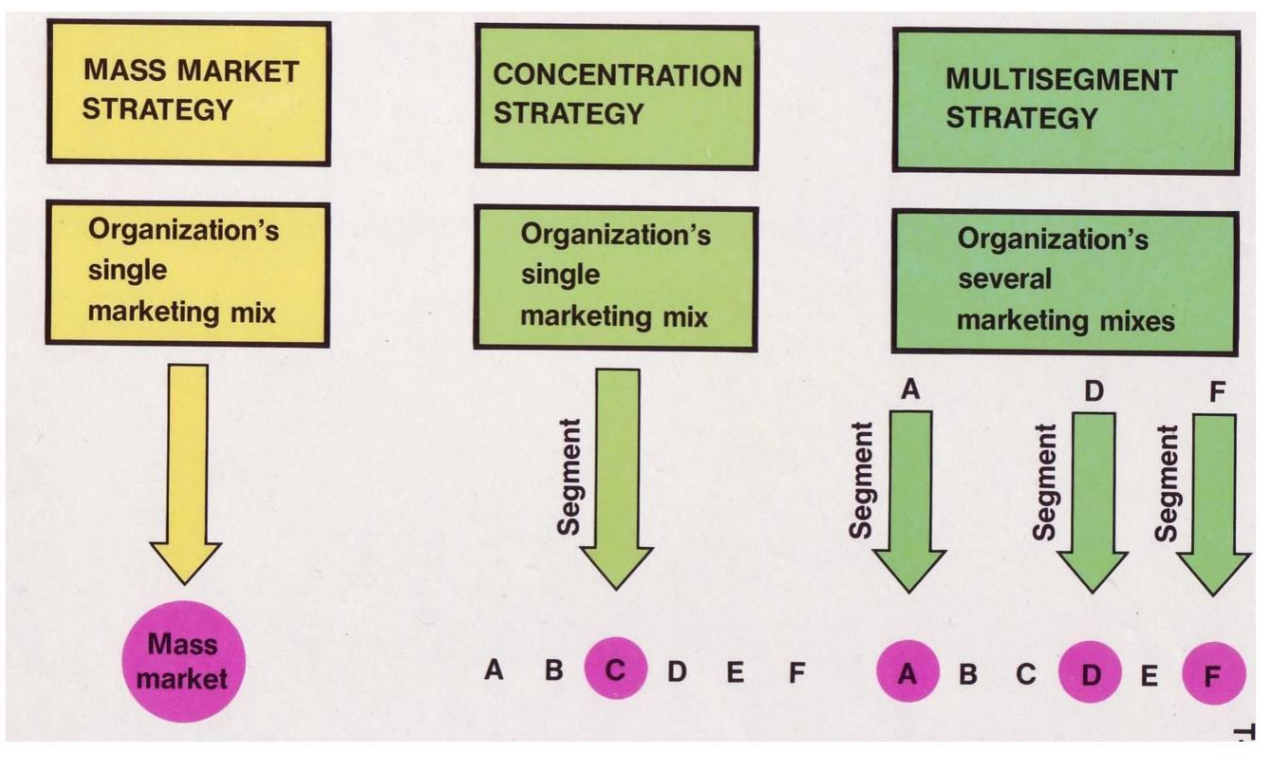

FIGURE 16. Market segmentation strategies (Gupta 2005, 70-77)

As can be seen from the figure, mass marketing strategy is noted as undifferentiated targeting whereas the market is seen as a group with no individual segments.in this situation, demand is homogenous, every customer has the same basic of needs that can be satisfied in the same way. Concentration strategy is used for a single market with a distant set of needs approach including niche marketing or one to one marketing. The last one is multi segment marketing strategy. This one is used for focusing on two or more target markets and wants to develop various strategies. Each segment will be treated as a unique market with different marketing mix. Selecting a target market will be based on company's resources, product variablities, product life cycle stages, market variablities, and competitors' marketing strategies. (Gupta 2005, 70-77)

-Focus on a single market segment 
In this case, companies can choose a market segment, this segment may have an available random match between customer needs and the products/ services of bank, would be a piece of this market consistent with the possibility of capital of companies is still limited, as the market may not have competitors, the market may be selected as the starting point for creating momentum for expanding business with the newly established small companies in the next year

-Specialization based on selection, products/services

This plan is conducted according to the way companies focusing on meeting demand of a particular market segment. This segment must be an attractive market, which is in accordance with marketing objectives and the ability of companies. This plan is suitable for small companies, which are less capable of coordinating multiple market segments together. For specialization on products/services, companies can focuses on providing a product and service that satisfies multiple market segments

-Covering the entire market

Under this plan, companies meet all customer needs and no limitations under certain customer groups. However, this method is only suitable for large companies, with strong financial capabilities.

\subsubsection{Positioning}

Positioning is what companies do to the mind of customer, not what companies do to products/services. It is the way companies develop their products/services in the mind of customers or improving their perceptions, feelings and impressions about product/services quality. In order to do that, companies need to have a strategic promotional activities or have a favorable marketing mix in which they need to identify a right possible competitive advantages to build a position strategy and develop position statement.Product, service, channel, people and image differentiation will be key factors help companies to provide excellent values to customers and from that identify set of positive strategic advantage to build a position. In order to have a qualified positioning stratetries, differences to 
promote must be important, distintive, communicable, affordable and profitable. (Market analysis 2010).

\subsection{Marketing mix}

After analyzing the business environment factors and knowing the advantages and difficulties of the current situation, companies need to develop marketing strategies consistently with the characteristics of business operating conditions in each period... (Uppal 2009)

7Ps Marketing mix which is popularly used in marketing plan is illustrated in the following figure.

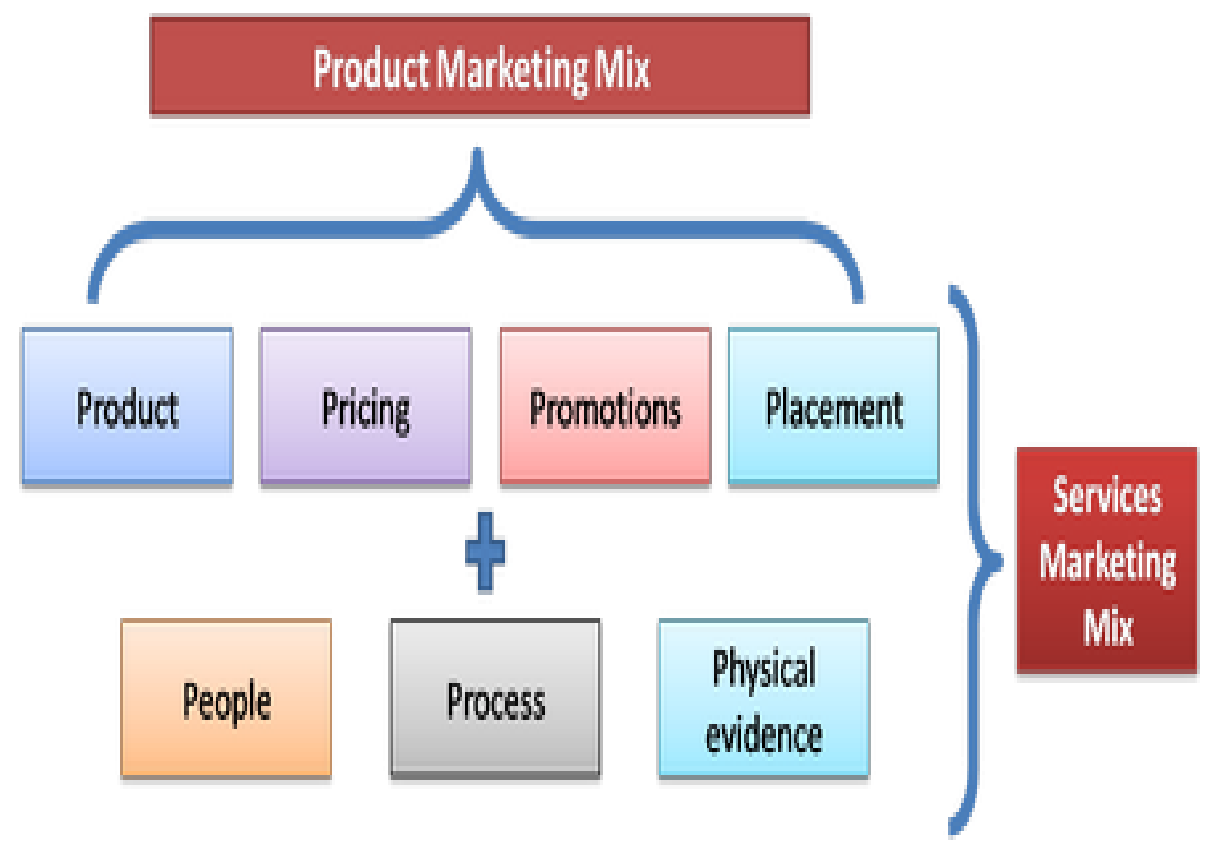

FIGURE 17. Service-marketing mix (Service marketing mix 2012)

Service marketing mix is always larger than product marketing mix due to its special characteristics as mentioned in the theory part. In order to access thoroughly to customers, companies need to also develop people, process, and physical evidence strategies beside of some basic marketing mix 4Ps. 


\subsubsection{Product strategies}

Product strategies are considered as the most important strategy in marketing mix strategies. According to Philip Kotler (Kotler \& Armstrong 2010, 163-164), product should be viewed in three levels.

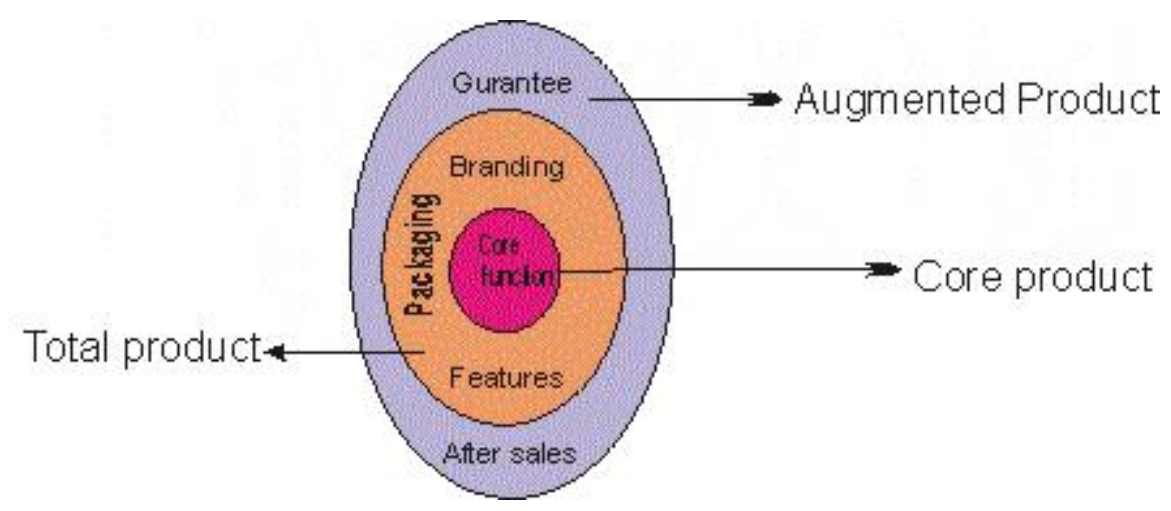

FIGURE 18. Product's level (Kotler \& Armstrong 2010, 163-164)

As the figure explains, in level one, core product describes the real benefit that customers can gain when deciding to buy it. Level two identifies an actual product which ensures that customers will purchase. This level involves in company's branding and features. Addionally, quality of a product is also supplemented so that products of companies are differentiated to other companies. The last one is augmented product. This will be stranded on criteria such as after sale services, waranties, delivery... Overall, when deciding to launch a nrw product to the market, many factors will have to be taken into consideration especially product design, quality, features and branding.

Along with the progress of science and technology, products/services are constantly innovated and improved in both quantity and quality. At the same time, society demand is increasing and changes frequently. In operation, companies always wants to create unique products to meet customer needs, so products services strategies will be sharp weapons in the competitive market as well as an effective method to generate new demand. (Shodhganga 2009). 
In contemplation of achieving goals set out in the business, companies need to fulfill evaluating existing products and developing diversification of products.

How to implement a product strategy effectively? The following points will fully describe:

- Companies must conduct market segmentation of the market according to the selection criteria.

- Product Research: Consider the reaction of customers when receiving products of companies

- Study the life cycle of products: Expression of getting the product in the market from the first time until the withdrawn time from the market. Product life cycle through four stages: deployment - growth - maturity - decline. Each stage of the product life cycle requires companies to have appropriate responses.

- Research customer cycle: companies shall classify customers according to performance characteristics, production and business, especially for seasonal businesses. For residential class, companies need to distinguish clients by age to know when customers need to send money, when to borrow money or to provide other services.

- Study the content and quality of products. Companies must regularly collect and analyze information from customers about the quality of products and services that companies provide to improve the product and offer the best products, best suited to the customers. (Shodhganga 2009)

\subsubsection{Pricing strategies}

Pricing is one of the most important factors in marketing mix, which impacts directly to the turnover of companies. When making a decision of pricing, companies has to take into account different factors such as fixed and variable cost, competition, company objectives, proposed positioning strategies, target group and willing to pay. There are various pricing strategies that can be used in 
marketing mix; however, there are seven main pricing strategies that are frequently used nowadays.

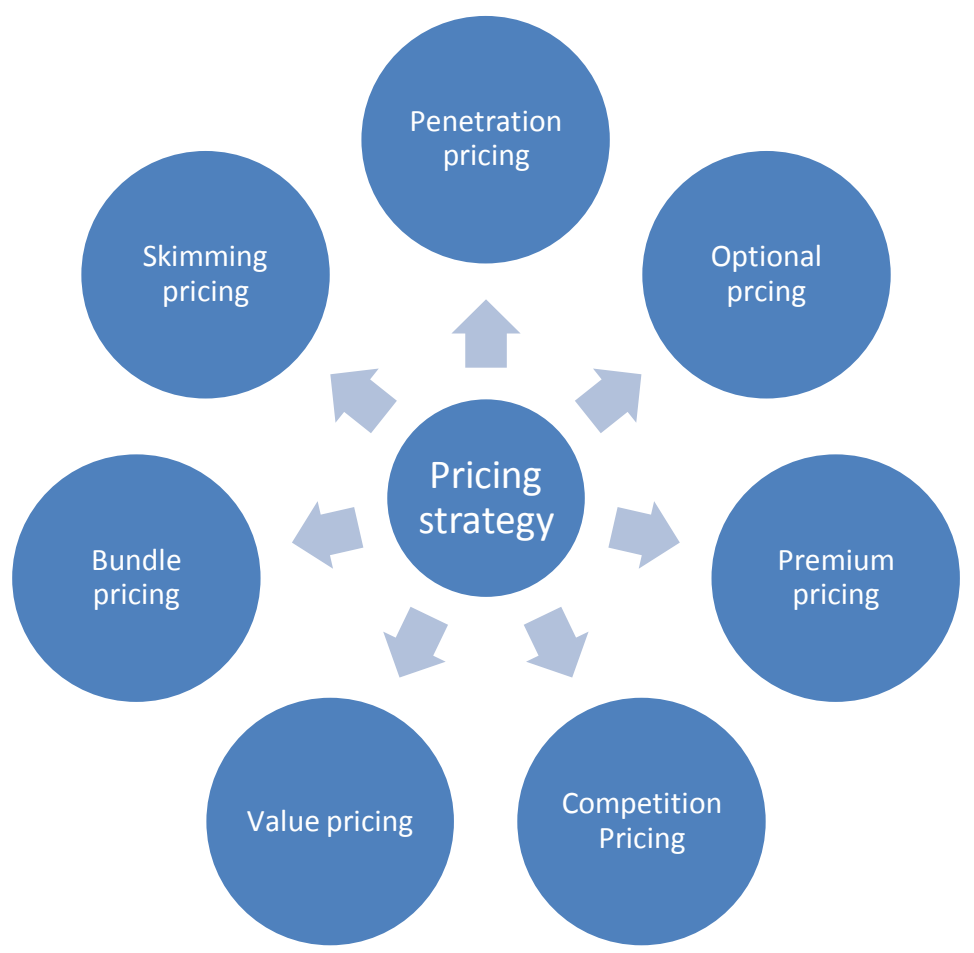

FIGURE 19. Pricing strategies (Monroe 2003, 30-45)

Penetration pricing is used for companies which just appear in the market. In order to gain market share and attract customer, they need to set a low price and once market share has been captured, they will gradually increase their price.

Skimming pricing is at first companies set high price and decreasingly make it lower to gain wider market. This strategy is usually employed only for a limited duration to cover investment capital.

Competittion pricing is seting price comparision with competitors. They may set higher or lower price depend on their strategic plan or company's objectives.

Premium price is high price which is set to reflect the product exclusiveness in order to encourage favorable perceptions among buyers, based solely on the price.

Bundle price is the way companies bundle a group of products at a reduced price. Common methods are buying one and geting one free promotions. 
Optional pricing is selling optional extras along with the product to maximise its turnover

Value pricing is basing on the value products have for customers and not on its costs of production or any other factors. This strategy is often used where the value to customers is many times the cost of producing the item or service. (Monroe 2003, 40-45)

Pricing strategies are not only competitive factor among companies but also a strong impact on the decision of products selected by customers.Prices in companies 's operations is the cost that customers pay for companies to use services provided by companies and the charges for companies to use client funds

This is the second factor of Marketing and is a key factor to determine the income of companies on the basis of assessment of the costs that companies give out. (Wykes 2010). In order to get a price to suit each customer group, not only brings profits for companies but also match the prices of competitors, the procedures outlines a pricing strategy is in following stages:

\begin{tabular}{|l|l|}
\hline 1 & - Identify market \\
\hline 3 & - Evaluate demand \\
\hline 4 & - Analysis demand \\
\hline 5 & - Research price's competitors \\
\hline 7 & - Identify price level \\
\hline
\end{tabular}

FIGURE 20. Pricing strategy process (Nguyen 2012, 24-27)

As can be seen from the figure, at first companies should identify the market based on their business and objectives. After that evaluating and anlyzing demands to figure out the trends of the market's demand,Companies will have to 
review the general direction of potential clients' demands as well as current customers. Following that is researching competitors's price and deciding which pricing strategies they should apply in order to adapt market's needs and satisfy customers. And the last one is identifying price level and making a decision on it. Conducting pricing strategy effectively will help companies to have a clear approach in rising profit for companies.

\subsubsection{Distribution strategies}

Formulating good strategies for products /services and price is not enough to ensure success in business. Marketing strategies are still required to build distribution strategies appropriately in order to ensure products and services offered to customers in the best way. (Banking Leaders Discuss 2014 Strategic Planning Priorities 2013)

The management of mixed distribution channels that achieve optimal efficiency has become a strategic issue of bank executives. Because of the choice of distribution channels not only affects income but also affect the pricing policy and product policy. Hence when choosing distribution channels, managers often set following requirements: Maintaining market share on the basis of maintaining and attracting customers, increasing combination of new distribution channels, but also ensuring the ability to respond flexibly to changes in the business environment and reducing costs and increase profits for companies.

Marketing tactics and strategies can be altered periodically with the minimum of difficulty for example pricing, packing. However, after defining which product will be offered to customer, product distribution seems to be much more difficult task to change. There are various distribution channels the company can use to "place" the products:

Retail outlets

Wholesale outlets

Direct mail 
Telemarketing

TV channel, home shopping

Personal selling...

Similar to physical product, service business can be offered through books or newsletters; email advertisment; sold at retail; or by phone, fax... In order to select the best distribution options, there are many factors marketers should examine for example

Examine competitor's distribution channel.

Evaluate the costs for each channel option.

Identify the most suitable to the company's marketing strategy.

(Staff 2012)

\subsubsection{Promotion strategies}

Promotions have become one of the most essential actions in boosting sales volume efforts. It is generally easy to realize that lot of companies are promoting themselves rigorously for the reason that competition is increasingly fierce and promotion therefore is a key to success. Thus companies always try to make themselves different from others by creative, attractive advertisements to gains higher customer's attention. Three basic objectives of promotion are presenting information to customers, increasing demand and differentiating a product. ( Gelder \& Woodcock 2003, 18-25)

In the business environment, companies have a system of complex communication connections: with customers, other financial institutions, the central bank ... As relationship is complex and intertwined, companies is responsible for forming and maintaining the product's image and their organization in the eyes of society and potential customers. For this, companies have to conduct promoting activities. These activities will make customers understanding clearly about companies and banking service, persuading them to 
use products/services and maintaining the relationship between companies and customers well. Promotion strategy plays an important role in bank marketing strategy because the employee's communication with customers will create the bank's image and create customer trust with companies. It supports for the strategy, create favorable conditions to implement three strategies above. (Zeiger 2009)

Promoting activities of companies include operating system information and communication on bank products/ services to customers such as advertising, personal transactions, communication, promotions, direct marketing, contest, coupons,....The process of promoting process is consisted of following steps:

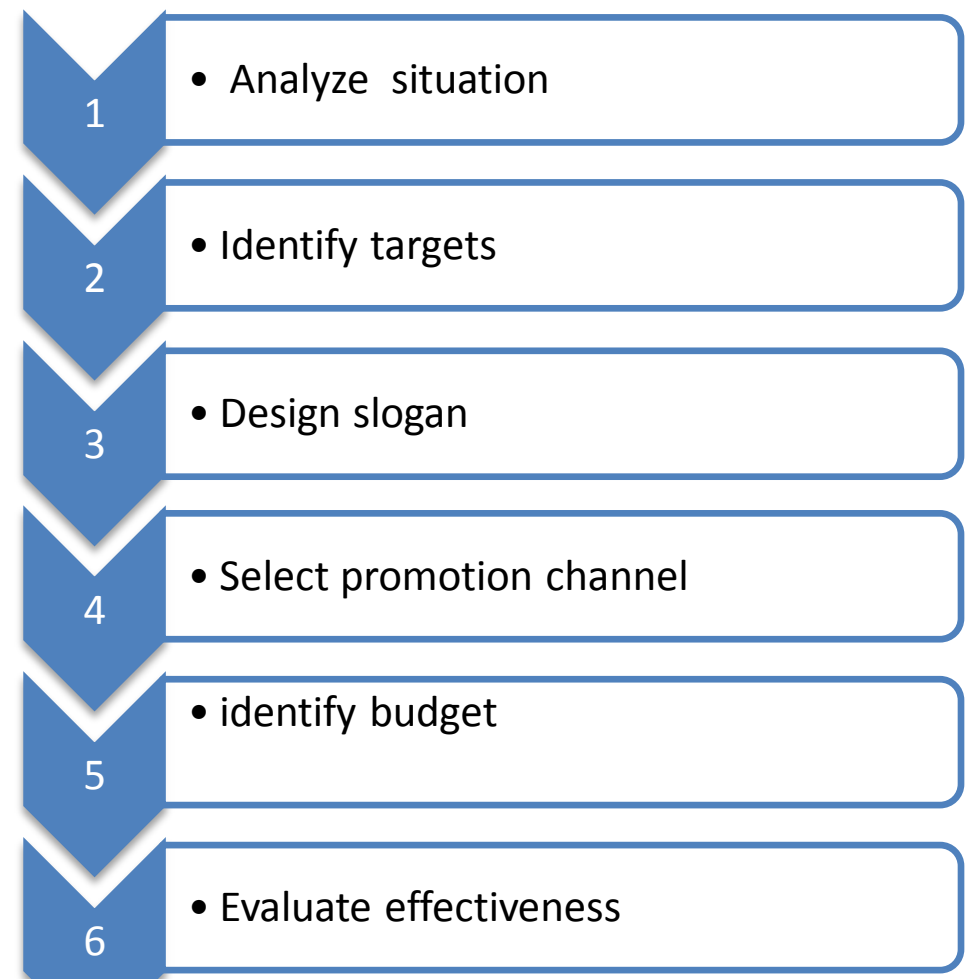

FIGURE 21. Promotion strategy (Nguyen 2012, 42-44)

In promotion strategy, companies always have to analyze the market situation and identify the target that they are going to introduce and develop their services/products there. Designing a slogan and selecting a proper promotion channel will help them to access all target market well. Hence, they can evaluate the effectiveness that companies can gain during the process. In fact, promotion 
activities bring more opportunities for business banking. This strategy is becoming increasingly important and indispensable in modern banking.

\subsubsection{Human Resource strategies}

If placement defines the services product location, people then define services/ products. Certainly, staff in one company with their behaviour towards customers will show a company's face. Thus people can evenly enhance or destroy the company image in certain ways. That is why nowadays every company tries to get staff trained in interpersonal skills and customer service in order to suite the customers' satisfaction.

Development of human resources including recruitment, assignment, training, evaluation, grasp aspirations, policies to encourage service and attract customers, improve competitiveness of the bank. Thus the goal of the strategy is to train people to become a professional staff with qualified skills and personalities needed to execute marketing activities and can create images for companies. (Human resources organizational development. 2010)

Structure of marketing department in bank

The organizational structure of the bank is an important component to implement the marketing strategy. All banking activities of the bank depend on how the organization is.

In spite of the fact that bank marketing appeared rather late, it has occupied a very important position in the organizational structure of the bank. Generally there are two types of Marketing department organizations: Marketing department organization type in the model of banking institutions and the Marketing department model independent of banking institutions. However, the first model revealed several limitations: Marketing activities are fragmented, unfocused synchronization. Marketing effectiveness will therefore low and cannot be identified specifically. Therefore, companies are now commonly used types of organizations in the second model that is the independent marketing department in the organizational structure of the bank. 
Organizational Chart of Marketing Department in the independent model of banking institutions:

In fact the structure of marketing departments can dynamically change depending on the tasks and functions of each bank but still Marketing is very important compared to the other parts so that it should be organized in a coherent way.

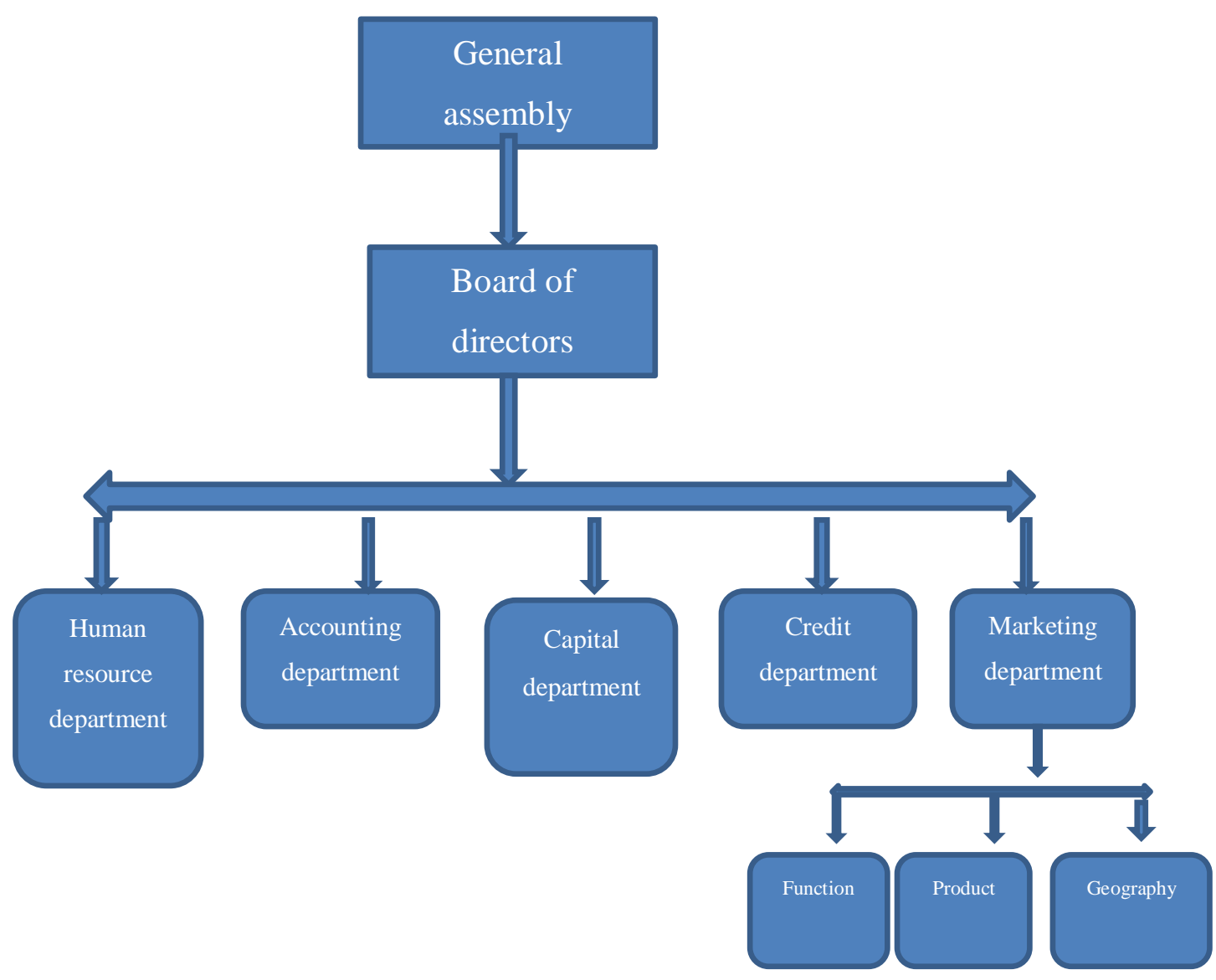

FIGURE 22. Organizational structure (Nguyen 2012, 47-49)

\subsubsection{Process strategies}

Process refers to the procedure, mechanisms or flows of activities by which the service is delivered to the customer. In another word, it means "easy to do business with". The more "high contact" service, the more it needs to get the process right. The right process is the process which improves the high experience 
of customer to the service and stands in the customer's point of view. The good process should be designed for the customer's convenience.

It is known that in a service environment, customers mostly have to queue before they can approach the server. That clearly means the customers have to wait for a certain time, a successful marketer is one who can create and manage the effective service processes that makes the customers understand the process and accept the length of waiting time.

As has been mentioned above, service is perishable which means it cannot be stored, inventoried for reuse or return. Thus managing service process factor plays an important role in marketing mix strategy. In add-on, due to the situation of under or over of demand, process management become a tough task for every marketer. However, thanks to the" blue print "method which helps to manage the dynamic and experimental service.

Shortcake, who invented the blue printing method, said that blue print service can bring back the idea of customer and employee encounter improvement. This method shows how the service provider can be empowered to manage the service components to create a bridge to the gap between customer demand and management intent. This gap typically means that the service operations are the middle factors in the relationship of the customer and the firm. Therefore, if service providers span the boundary between a firm and its customers, customers may become frustrated. (Itd 2013).

A service blue print is an essential tool which can be used to describe and analyse all the processes relating to provide the service. Typical service blue print uses to manage the service quality commonly includes designing new services, evaluating services and reconstruct if needed as well as controlling service delivery. (Brown 1992, 73-74).

\subsubsection{Physical evidence strategies}

The last element in the service marketing mix, 7Ps, are widely used as a differentiator in service marketing. Physical evidence refers to everything tangible which could include some of the following buildings, equipment, signs and logos, 
annual accounts and business reports, brochures, website and even paper works. (Lesson physical evidence 2011).

Services are largely intangible when marketing and customers tend to rely on physical cues to help them evaluate the product before they buy it. What is physical signal for service? Thanks to what we call physical evidence in marketing mix strategy, it helps companies to facilitate the purchase and consumption of an intangible service product such as credit cards for banking services. Additionally, physical evidence creates the "environment" or "atmosphere" where service is bought or performed and can raise customer's perception toward to the provided service. ( (Fifield 2012, 242-243).

Some organizations rely mostly upon physical evidence as a useful tool of marketing communications, for example parcel and mail services (DHL Courier Services), tourism attractions and resorts (Disney World), and large companies and insurance companies (HSBC, Prudential ). (Lesson physical evidence 2011)

According to Jim Blythe, there are four generic ways to add value through physical evidence: (Blythe 2006, 718)

Create Physical evidence which increases loyalty

Use physical evidence which has an inherent value of its own

Create physical evidence which will affect further sales

Use physical evidence to enhance brand image

As physical evidence provides many benefits for companies to capture customer's loyalty, what should marketer do with physical evidence or how to manage physical evidence?

In the book "Service marketing, the Indian context, R.Sirnivasan said that service firms should manage physical evidence as following activities: (Srinivasan 2012)

- Packing the service: packing is the important role in adding value to the service and creating a positive image. Positive image can reduce perceived risk level 
coming with purchase while it also forms the customer's first impression regarding of the quality and type of service produced.

- Facilitating the flow of the service delivery process: Physical evidence helps companies to create the positive service which provide information to either customer or process. It confirms again which service the firm's offers and facilitate mutual price evaluation by the customer.

- Socializing customer and personnel alike in terms of their respective roles, behaviour and relationship. For the fact the personnel is the face of firms, the image of the company is the image of each employee when he communicate with customers.

- Differentiating a firm from its competitors. For example, American airline's new strategy attracts more economy class customers from its competitors. This strategy invests more than $\$ 70$ million to refurbish the airline's fleets then provides economy class customers more legroom which they had never had before. In this way, the airline has more customers because of its more convenient services than other airlines. (Plane seats get bigger, cost more: Airline betting filter will pay extra for added legroom 2000)

One well-equipped bank will always leave the "only offer basic functions" companies faraway. HSBC bank system offers customer beautiful design chairs and wide customer service room hence such fresh and comfortable environments help them to attract customers more than other competitors

\section{SOR framework to approach physical evidence:}

Environmental psychology plays an important role in helping physical evidence to create service environments and influence their' perception and behaviour. The 
figure below will help to explain the effects of service environment on customer's

behaviour.

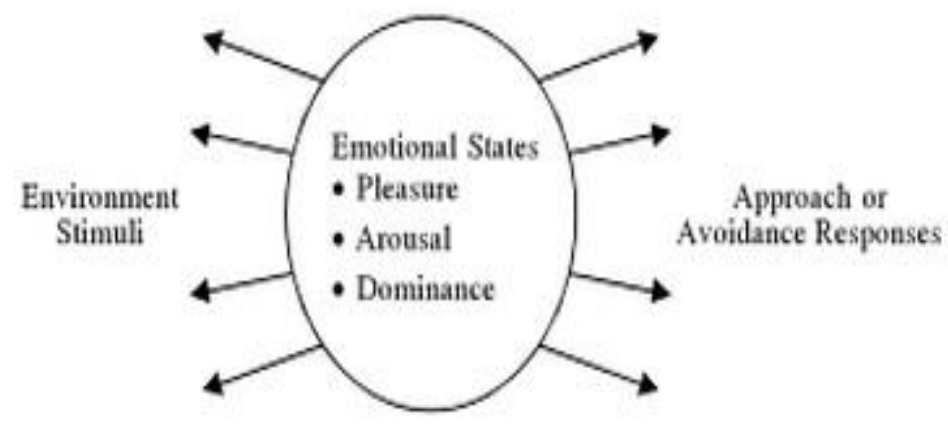

FIGURE 23. Three component of the SOR model (Rober \& John 1982)

There are three component of an SOR model:

Stimuli-includes various elements of physical evidence for example exterior and interior design, lighting, music,

Organism- refers to the recipients of stimuli who can be the customer or employee.

Response or outcome- how recipient response to the stimuli will depend on the emotional state of pleasure/displeasure, arousal/non arousal, dominance/submission. Pleasure or displeasure refers to the satisfactions of customer and employee to the service experience while arousal or non-arousal makes sure they feel excited about the service or not. Dominance or submission reflects to the free rights control level of both customer and employee in service encounter.

The approach or avoidance responses of the environmental stimuli are characterized by fourth behaviours patterns below:

- A wish to stay (approach)/ avoid the service environment.

- A wish to explore and interact (approach) with the service environment in the future or to ignore it. (Avoid)

- A need to communicate with others (approach) or to deny (avoid) the service provider's attempt to communicate with customers. 
- Experiencing the satisfaction (approach) or dissatisfaction (avoid) of the service providers. 


\section{CASE: SACOMBANK'S SERVICE MARKETING PLAN}

According to many economic forecasts, the world economy in 2013 will continue to be complicated and unpredictable .In many countries, besides intrinsic limitations of the economy, the crisis has also had evident impact in many fields and industries, especially export-import, investment and tourism. For banking operations, business environment in the tumultuous 2012 has caused difficulties and increased the risk of potential risk, particularly liquidity risk, maturity risk and status increased delinquency. These tough obstacles draw a gloomy picture for Vietnam's economic situation in general and financial market in particular.

This chapter is written to follow the thesis's objective: what to analyze in a marketing plan. Therefore, an "alike theoretical framwrok" practical framework has been created so that besides bringing the theory into real situation for analyzing certains factors, the Authors also suggest some ideas which are approached at practical level. They are all gathered to enhance a marketing plan for Sacombank.

\subsection{Sacombank profile}

Sacombank is ranked as the $3^{\text {rd }}$ out of 101 companies in Vietnam which plays an important role in Vietnam's banking development. Sacombank headquarters is located in Ho Chi Minh City. Nowadays Sacombank has 71 branches nationwide and 1 branch in Laos, 5 branches in Cambodia, 1 representative office in China including 340 transaction offices with more than 10000 staff. (Nguyen 2012, 6)

\section{Vision}

Sacombank aims to be the first modern multi-functional retail bank in Indochina region.

\section{Mission}

Maximizing customer value, investors, staff and maintaining the bank's highest commitment to corporate social responsibility 
Core Values:

TABLE 1. Sacombank core value (Nguyen 2012, 4)

\begin{tabular}{|l|l|}
\hline Pioneering & $\begin{array}{l}\text { Sacombank will be the leader and set up the new } \\
\text { growth areas in solving difficulties }\end{array}$ \\
\hline $\begin{array}{l}\text { Novel, Dynamic } \\
\text { and Inovative }\end{array}$ & $\begin{array}{l}\text { The bank believes that changing is a perceptual and } \\
\text { also the force of development. Therefore the bank } \\
\text { must adopt new and creative of strategic thinking that } \\
\text { will dynamically transform challenges into } \\
\text { opportunities. }\end{array}$ \\
\hline High & $\begin{array}{l}\text { Sacombank commits that all staff will continuously } \\
\text { improve; by means of training and development to } \\
\text { ensure that they consistently exercise professionalism } \\
\text { in providing the highest service quality to its } \\
\text { customers and partners. }\end{array}$ \\
\hline Rosponsibility & $\begin{array}{l}\text { Sacombank always peruses its slogan of "Serving the } \\
\text { Nations" and that corporate social responsibility is } \\
\text { deeply understood by every staff member. } \\
\text { aspects of its operations thereby creating optimal }\end{array}$ \\
\hline competitive advantage
\end{tabular}


Historic milestone:

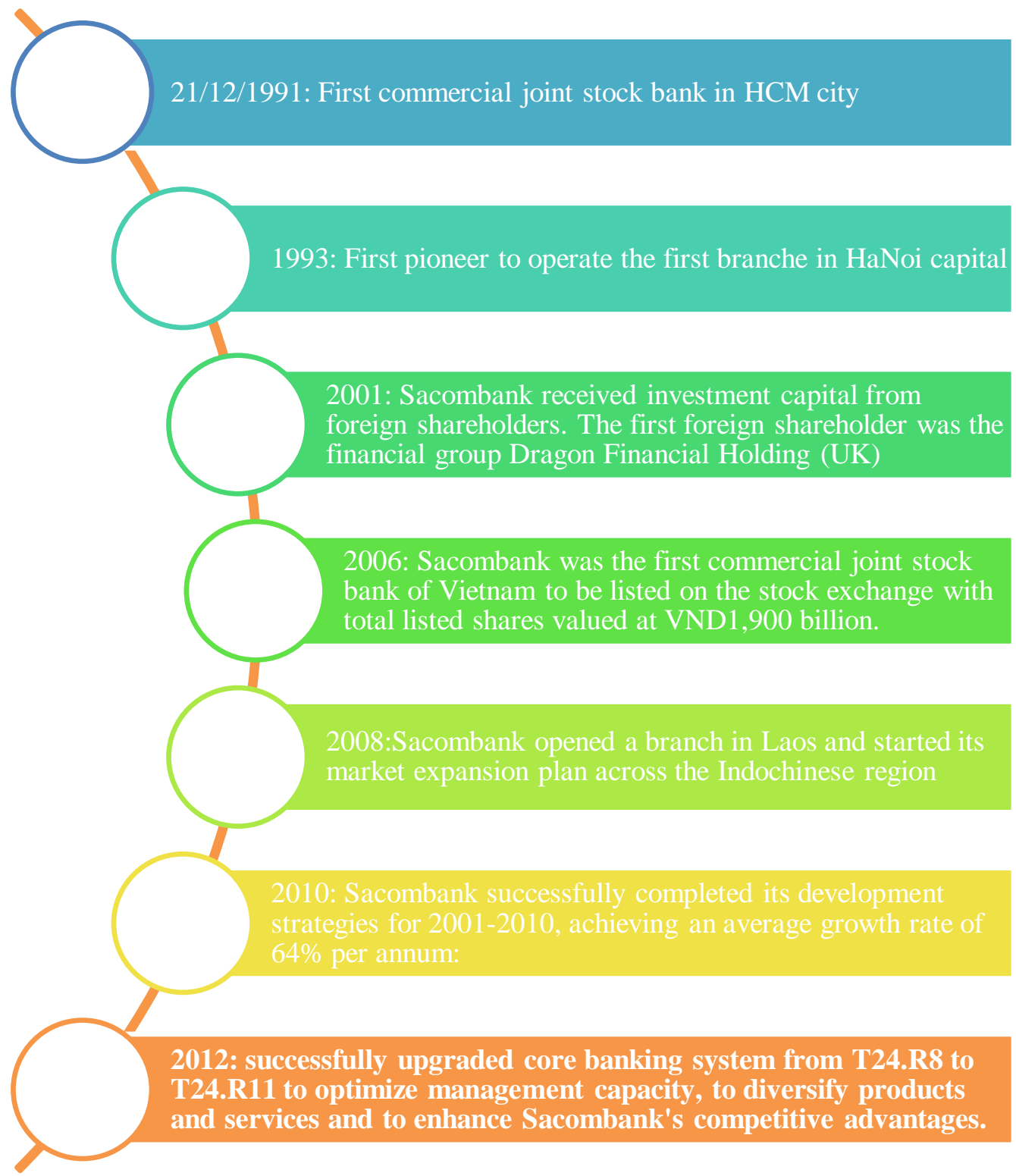

FIGURE 24. Sacombank Historic milestone (Tran 2012, 3)

More details about Sacombank history will be explained in Appendix 1.

Sacombank's historic milestone. 


\subsection{Situation analysis}

As the banking market changes unexpectedly, Sacombank advocates continuing to maintain perspective: "Safety is top priority". This stage combines two tasks seamlessly between consolidation and development:

Firstly, maintaining the harmony between safety goals and performances by focusing on increasing total assets and equity to finance capacity building.

Secondly, developing the capacity and improving governance in order to accelerate the process of restructuring all aspects of the Bank's operations. Including:

- Pursuing rapid completion apparatus and restructuring of personnel records, improve the quality of human resources.

- Restructuring policies, restructuring business operations and restructured asset portfolio and financial structure.

- Improving technology so that the bank will have significant network expansion to dominate the market, increase market share, deploy new products and services and enhance risk management capabilities.

To sum up, this strategy will help Sacombank to "turn the opportunity into a comparative advantage - competitive variables into development dynamics turned some sections lack the strong collaborative partnership - and turn challenges into lever to accelerate the integration process. (Vu 2011, 15-17)

\subsubsection{Internal environment}

\section{Financial capability}

Sacombank realizes that financial capabilities play an important role in the development of the bank. In order to invest technology and infrastructure, it is critical for them to have a huge amount of capital. Not only paying attention in concentrating to develop strategies but also trying to attract more capital by issuing shares and getting listed in the stock exchange. According to statistic 
2012, Sacombank has 63.894 shareholders with the total asset of VND 151282 billion, an increase of $8 \%$ comparing to total asset of year 2011.With strong financial position and structure, Sacombank has turned challenges into opportunities and become the pioneer bank to receive capital resource at reasonable rates from international financial institutions. (Sacombank's analysis 2011, 5)

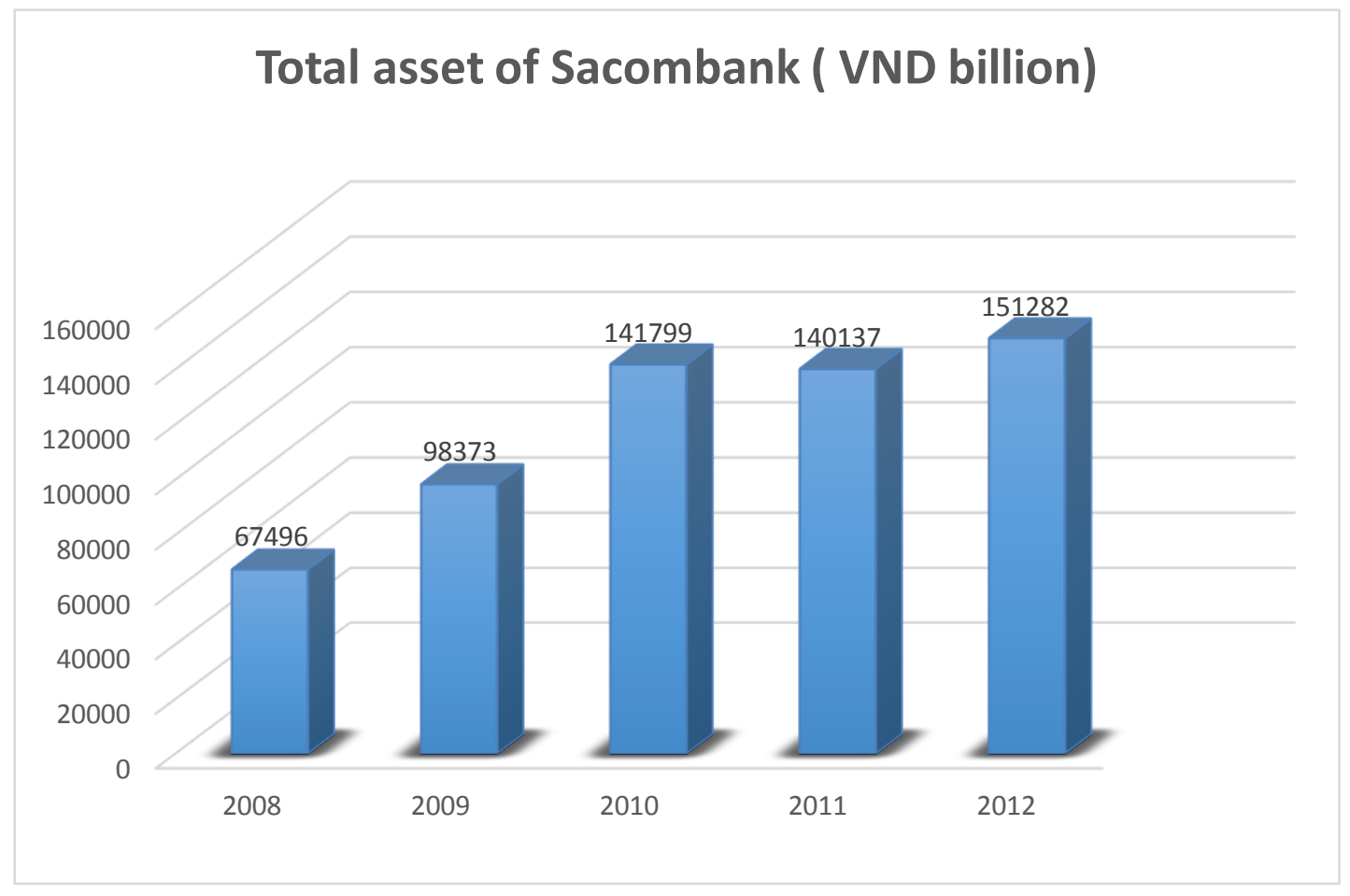

FIGURE 25. Total asset of Sacombank (Tran 2012, 10)

As the figure illustrates, total asset of Sacombank increases constantly except of the year 2011 due to the economic crisis. Just in four years from 2008-2012, Sacombank has set the dramatic development through attracting capital. Their total asset in 2012 is more than double comparing to 2008.Besides, the total asset structure also changes with improvement of stability and safety criteria: deposits from the market accounts for $67 \%$ of total asset, so the bank enjoyed the stable liquidity and was always ready to meet funding demands as well as cope with market changes. (Tran 2012, 10-12)

\section{Human resources}


Human resources is an important factor for development and success. In order to guarantee quantity as well as quality of human resource in Sacombank, they has conducted various implementation of the following measures:

- Paying more attention to the recruitment of staff with adequate qualifications and degrees. In Vietnam, the annual system of universities and colleges offer thousands of university students in Banking and Finance. Annually, Sacombank has the policy to recruit practical trainees nationwide and from that, they will have the contest among them to recruit qualified staff. One specialty in Sacombank is that they have the slogan only recruiting people who have just graduate from university and still have not had any experiences yet. This made them unique among other companies and they believe that this activity will help them to have an enthusiastic, young, positive and potential staff.

- Keeping skilled and qualified staff to work permanently in the bank in such current market economic conditions is also a challenge for Sacombank. As a consequence, they always have to launch many programs and strategies to attract talented people. By late 2012, Sacombank had 10,149 employees, an increase of 759 people $(+7,5 \%)$ from 2011 . There are $70 \%$ less than 30 years old on average and most of them are well trained and fully meet Companies's requirements on quantity and quality. The bank also provided 1663 training courses with 33,618 attendances by employees and developed an in-house trainer team of 660 members. (Vu 2011, 9-12)

- Education level's employees: Most employees are university graduates, besides there are a number of employees in the process of working who also want to improve their qualification. They have automatically registered Master degree course to have a better future.

\section{Reputation and customer impression}

During the crisis, Sacombank being a pioneer in the adjustment of interest rates has created a good impression in the customers' mind. That has helped the enterprise to overcome difficulties during the crisis. At the same time, customers' classification to apply the interest rate has also been done well in recent years bringing the particular effect which customers also evaluate very highly. 
The credit policy in many programs has received lots of supports and trust. It is also working to keep commitments to customers under the program. This policy not only supports clients to overcome difficulties during the current situation but also adjusts interest rates more suitable with market developments.

\section{Infrastructure elements}

Facilities of modern office equipment create the best conditions for staff and employees to complete tasks. Each employee is equipped with their own computer for convenient working.

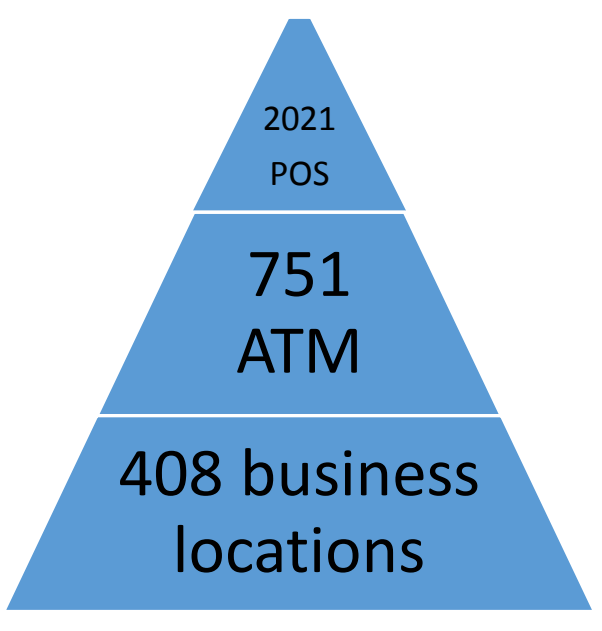

2011

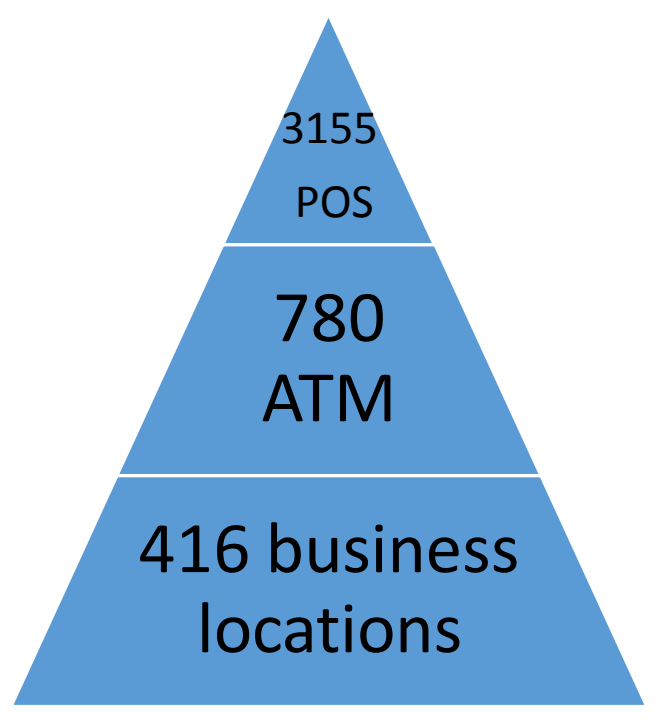

2012

FIGURE 26. Infrastructure of Sacombank (Tran 2012, 13)

As the figure shows, in one year from 2011 to 2012, there is also a dramatic change in infrastructure of Sacombank. It has been decided to broaden and have more business locations nationwide as well as some transaction offices in Laos, Cambodia and one representative office in China. Besides, they also invest in ATM machine systems as well as POS service so that customer satisfaction can be higher and enhance their image not only in central cities but also in remote and rural regions. (Tran 2012, 13)

\section{Organization and management}


The management structure is organized according to the structure function with the clear consistence. Operational management has easy and high working efficiency.

The system of internal bank information is well organized; departments can communicate with each other easily. Information from outside is also linked in a systematic way. Currently, Sacombank has set up its own website: sacombank.com.vn. This channel is a very useful tool to help the company put news of their activities to the public such as information about the Bank, the situation of market volatility, news events, and updates of gold price. Promotions, information on new products are also regularly updated and accurated. (Nguyen 2012, 20-22)

\section{Corporate Culture}

Providing uniforms for women (long dress, skirt and shirt) or tie and white shirt for men will leave a good impression in customers'minds.

Regularly organizing social events, trips for employees in some special occasions such as International women's day, Independence Day... is a good opportunity for people to learn and experience together.

For customers, the staff always takes thoughtful guidance and answers questions carefully for customers. (Nguyen 2012, 23)

\subsubsection{External environment}

\section{Market situation analysis}

Vietnam's economy since 1990 has never been unstable like nowadays. Currency markets are more signs of credit liquidity. The stock market is always in a state of instability. The real estate market is frozen and increasing signs of serious deterioration. Inflation of main items of the economy is not a positive sign. More serious problems in the economy are being faced without exit. Causes affecting the status of Vietnam's economy above are primarily due to the economic crisis of the world. 
The unstable economy has made inflation increasing greatly compared with the previous year.

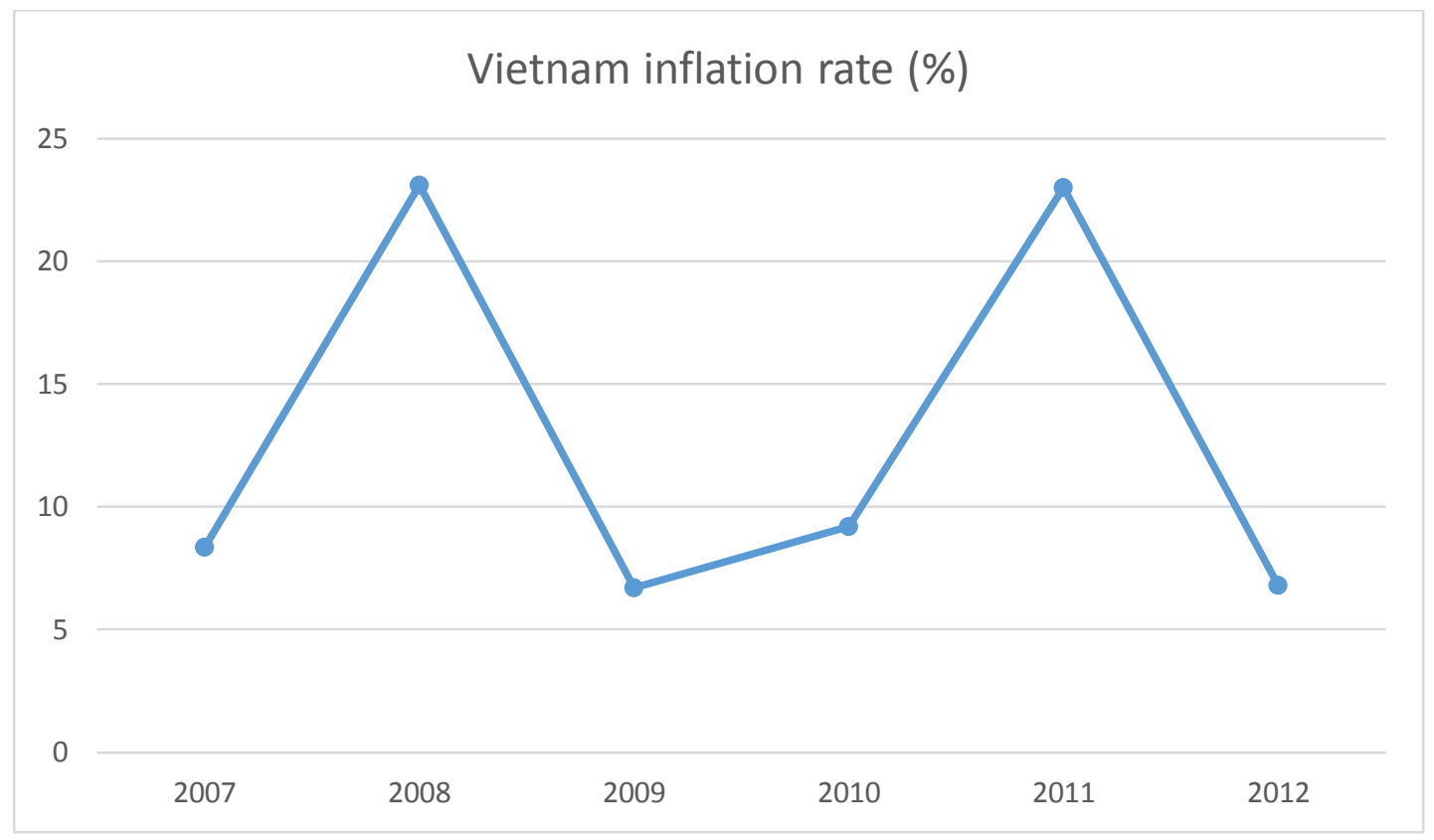

FIGURE 27. Vietnam's inflation rate (Inflation rate 2012)

As can be seen from the chart above, in 2008, inflation in Vietnam is more than $28 \%$. It was running substantially higher elsewhere in frontier and emerging markets. This was again the case in 2011, when inflation climbed to $>23 \%$. Both of the episodes were originated from external shocks. Despite inflation's turn downin 2012, it still has a serious impact on the banking industry. In this situation, the government has set out the monetary policy operating credit, and inflation measures in an effective manner. The solution is based on the antiinflation monetary policy in Vietnam including basics such as rising interest rates, increasing reserve requirement ratio for companies, withdrawing money from circulation, withdrawing money in payment of commercial companies to fight inflation. (Inflation rate 2012)

The money market and the stock market as two communicating vessels in the circulation of capital will also affect the stock price, as well as the flows of capital transferred from the stock market to money market or vice versa . In addition, stock market development is creating new tools, enabling commercial companies to expand the ability to participate in the currency market operations. This promotes development of money markets, and supports central companies to 
implement monetary regulatory role through the tool market indicators, especially through open market operations. The purchase and sale of securities of state companies with commercial companies will have the effect of expanding or shrinking the volume of currency in circulation, through which the monetary amount is regulated according to defined objectives. (Staff 2012)

\section{Sacombank position in Vietnam}

Currently, Sacombank is responsible for many large projects with national importance. Moreover, the bank aims to become a strong financial group in various fields: insurance, securities and investment.

As one of the biggest commercial banks in Vietnam, in the recent past, Sacombank has always worked closely with the business. In addition to preferential interest rates, they also offer package solutions for small and mediumsized enterprises (SMEs). Moreover, Sacombank has always been "maestro" in the forum for investment promotion of the country. They not only help enterprises to overcome difficulties, but also open up many opportunities to support business development in the future. ( $\mathrm{Vu} 2011,15-16$ )

Sacombank is a pioneer in social welfare activities for many years. The Bank's social activities are effective and create a lot of benefits for the community.

In a nutshell, through many community-oriented activities, Sacombank is now holding the important position in the Vietnamese finance market.

\section{Politics - law}

Vietnam joined the WTO opening up many opportunities and new challenges. To ease the accession, the government allowed companies with $100 \%$ foreign investment in Vietnam. This has increased competition among companies. Consequently, small companies have been forced to raise equity capital and human resources policies in order to compete with foreign companies which have strong advantags of human resources and capital.This fact can be seen as a huge challenge for Sacombank as well. 
Besides, Vietnam is highly appreciated for its political stability with the underlying vulnerability index of 2.5, the economic distress index of 6.0 and the total stability index of 4.3 during the period 2009/2010. That is why the country is ranked $27^{\text {th }}$ out of 165 countries surveyed and categorized as a country with moderate risk. In addition, international relations have been extended to the following aspects: economy, culture, science and technology ... Political stability and the improvement of legal issues help Vietnam to attract more investors in all sectors which lead banking transactions to grow increasingly. (Vu 2011, 17-22)

However, Vietnam is unfortunately suffering from an unclear legal system that could create much headache for international investors. Many foreign investors have met many challenges and obstacles in the legal system when deciding to enter Vietnam market. This has limited an amount of opportunities for Vietnam to attract more investors.

\section{Economy}

Vietnam is on the integration stage to the world economic development. Over the the last over 30 years, the country had to suffer from harsh continuous war and the collapse of the old Soviet Union. This had hindered Vietnam from development while other countries have turned into the other developing stage already.

Vietnam conducted economic renovation in 1986 when moving to a socialistoriented market economy in implementation of industrialization, modernization and initiation of open door policy to the world. Vietnam has become a leading agricultural exporter and an attractive destination for foreign investment.

The table below shows some basic figures and numbers about the economy of Vietnam in 2011: 
TABLE 2. Vietnam's statistics 2011 (Socio- economic statistics 2011 2011)

\begin{tabular}{|l|l|}
\hline GDP Official exchange rate & $\mathbf{\$ 1 2 0 . 8}$ billion \\
\hline GDP Real growth rate & $5.9 \%$ \\
\hline GDP per capita & $\$ 3,400$ \\
\hline GDP by sector & $\begin{array}{l}\text { Agriculture } 22 \%, \text { Industry } 40.3 \%, \\
\text { Service } 37.7 \%\end{array}$ \\
\hline Labour force & 48.23 million \\
\hline Exports & $\$ 96.91$ billion \\
\hline Imports & $\$ 97.36$ billion \\
\hline Unemployment rate & $3.6 \%$ \\
\hline Investment & $34.6 \%$ of GDP \\
\hline Budget & Revenues: $\$ 34.09$ billion \\
\hline Public debt & $48.8 \%$ of GDP \\
\hline
\end{tabular}

As the table shows, GDP growth rate is $5.9 \%$. It is ranked the first in the world for economic growth. Economic sector structures orientate toward the development of a multi-sector commodity economy. In spite of the fact that the 
economy is still dominanted by stated-owned enterprises, private companies are now also gradually protected by new policies issued by the government.

However, there is an imbalance in Vietnam's economic sectors. Whiles agriculture plays an important role and occupies a huge amount of the workforce, service and industry are still not developing very much comparing to their potential. One more disadvantage is that Vietnam's principal exports are raw materials while they have to be highly dependent on high tech devices and products imported from abroad. The figure below will make a clarification of Vietnam import/export situation nowadays.

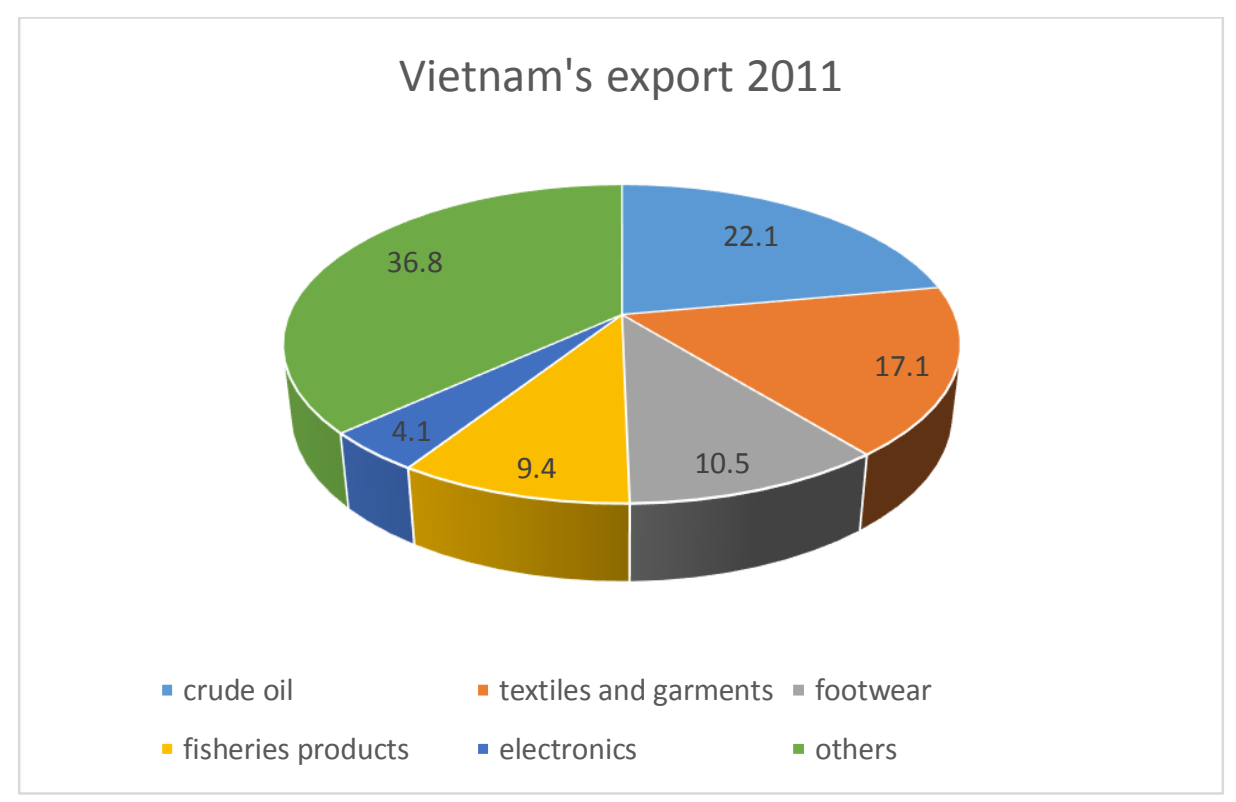




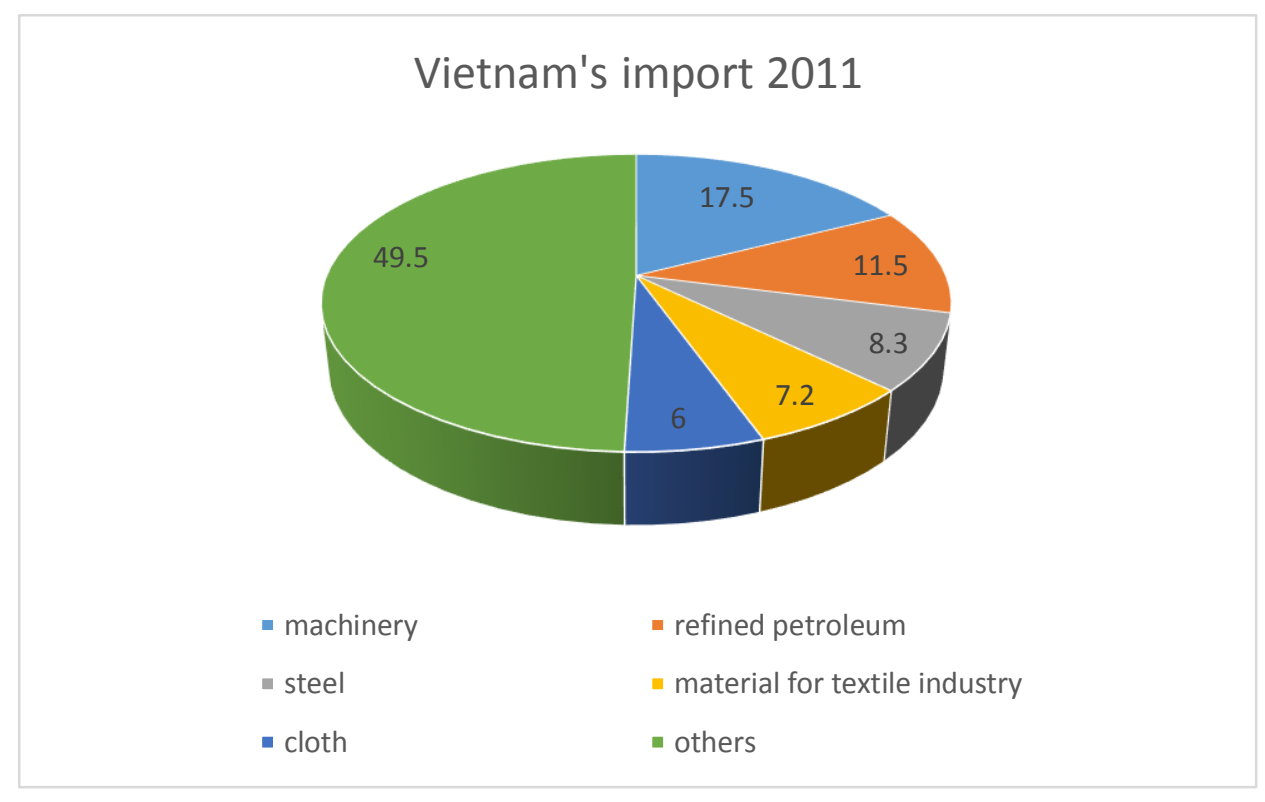

FIGURE 28. Vietnam import/export 2011 (Hoang 2011, 13-15)

Due to the lack of high technology and proper manufacturing, Vietnam's principal exports are raw materials sold at relatively cheap price compared to other nations. That is why Vietnam's exports of merchandise revenue are still lower than other nations. The government is trying to invest more in high technology and knowledge to get competitive advantages.

The country's economic reforms have enhanced Vietnam's competitive position in the world as $14^{\text {th }}$ ranked among the most attractive emerging markets by AT Kearney in 2012, surpassing many other potential countries. The details are presented in Table 3. (Hoang 2011, 17) 
TABLE 3. The most attractive emerging markets 2010(Hoang 2011, 18)

\begin{tabular}{|c|c|c|c|c|c|}
\hline 2012 & Country & $\begin{array}{l}\text { Market } \\
\text { attractiveness }\end{array}$ & Country risk & $\begin{array}{l}\text { Market } \\
\text { saturation }\end{array}$ & $\begin{array}{l}\text { GRDI } \\
\text { score }\end{array}$ \\
\hline 1 & China & 50.06 & 85.8 & 32.9 & 64.0 \\
\hline 2 & Kuwait & 75.4 & 94.3 & 56.2 & 62.6 \\
\hline 3 & India & 35.4 & 51.3 & 62.2 & 61.7 \\
\hline 4 & Saudi Arabia & 65.3 & 86.5 & 50.7 & 58.6 \\
\hline 5 & Brazil & 73.5 & 74.3 & 46.6 & 57.8 \\
\hline 6 & Chile & 71.8 & 92.3 & 27.5 & 57.5 \\
\hline 7 & UAE & 79.1 & 100 & 18.8 & 57.5 \\
\hline 8 & Uruguay & 67.7 & 74.3 & 58.6 & 55.9 \\
\hline 9 & Peru & 43.3 & 54.6 & 72.2 & 54.9 \\
\hline 10 & Russia & 63.5 & 55.1 & 32.0 & 53.1 \\
\hline 11 & $\begin{array}{l}\text { Tunisia } \\
\text { Albania }\end{array}$ & 45.3 & 77.1 & 61.3 & 52.5 \\
\hline 12 & & 30.4 & 30.2 & 82.2 & 51.1 \\
\hline 13 & Egypt & 30.9 & 45.5 & 85.7 & 50.9 \\
\hline & Vietnam & & & & \\
\hline 14 & & 12.3 & 49.4 & 50.2 & 50.2 \\
\hline
\end{tabular}

In a nutshell, Vietnam can be seen as a country full of potential for any foreign investor who wants to enter into this market. Besides political stability, natural resource diversity and cheap labor force, there are also some disadvantages that investors should be concerned about when making a decision to invest in Vietnam, like the legal system and unstable economy ... 


\section{Social}

Since over $50 \%$ of the population is agricultural laborers, there are some sociocultural factors that negatively affect banking activities, such as ordinary people dealing with big companies, not relying on small companies. They also have more faith in governmental banks than commercial banks.

The more increasing urbanization speed is, the higher living standards and cultural level of the people are. Subsequently, advantages of social culture are partially correct. Along with the process of economic integration, social and cultural factors have more positive effects in active economic sectors. (Staff 2012)

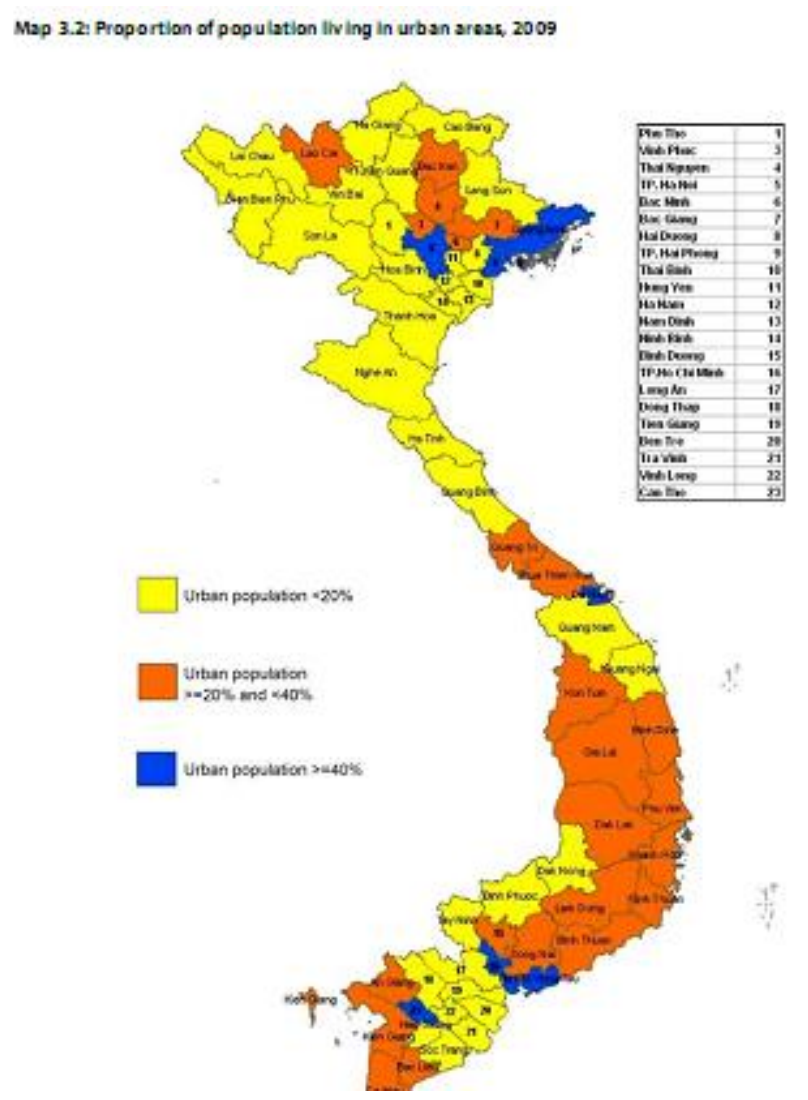

FIGURE 29. Propotion of population living in urban area 2011 (Tran 2012, 17)

As the figure shows, urbanization in Vietnam is rapidly increasing, at a rate of $3.4 \%$, which mostly happens in the two biggest cities, Hanoi and Hochiminh city. Urbanization, especially in those large economic centers, will have a critial role in Vietnam's economic growth as well as Banking service. 
Vietnam is a country with a young population structure with more than 90 million people. The working age accounts for a large proportion, $45.67 \%$ of the total population especially workers in banking and finance sector is increasing over the years from $4.4 \%$ to $5.2 \%$ according to the GSO resource. This shows considerable advantages including development of human resources for the bank's future.

Besides, according to the internet center in Vietnam in 2008, the number of people accessing the internet is 30.2 million accounted for $30.4 \%$ of the total population. However, in order to use this human resource the most effective way in the future, right now the bank should have policies to attract, train and nurture the right talent for banking and financial sector as well. This helps the bank to be more active in using employees, while avoiding the lack of qualified personnel in leadership positions. (Staff 2012)

\section{Technology}

The rapid development of science and technology has changed the face of the banking system. Sacombank has taken advantage of the development of technology to modernize the public administration and the service dealing with domestic and foreign partners. After 20 years of renovation, Vietnam's banking system has developed information technology infrastructures which are relatively uniform and modern. There are many facilities that have been mined and used to serve the needs of economic development, social integration. In 1986, Vietnam's banks began to use the computer system in central bank as well as branches. Besides, application OS MS - DOS and database FoxPro to perform the last trading day of accounting, balance sheet, and savings are also performed. Period 1990 - 1998 was considered as the first phase of the renovation period for banking industry and services. Key applications such as account opening, ATM installation, international money transfer, interbank payments have been utilized effectively. Apart from state-owned companies, the credit institution has established information technology center equipped with its own hardware, system software, and new technology products. Scale applications are extended from the central bank to branches and computer systems are linked on the basis of wide area networks in the industry. (Nguyen 2012, 28-31) 
It can be said that the development and application of modern technology in banking not only has facilitated the speed of business operations and development but also improved business efficiency and competitive capacity. In addition, the bank should strengthen joint activities not only to take advantage of the network and modern technology but also improving investment performance which may help credit institutions to lower their services of deployment and development.

\section{Environment}

Vietnam is a country located in the tropical regions near the equator together with a long coastline which always has to suffer from strong storms annually. The climate and weather complexity haved caused a negative impact on farmers' crops, infrastructure and people's lives. This results in reduced living standards and reduction of income. Those are unfavorable conditions for business activities of the bank.

According to the Vietnamese Ministry of agriculture and rural development, Vietnam is estimated to lose around $1.5 \%$ of GDP annually due to property damage caused by natural disasters. Moreover, in recent years, natural disasters tend to occur more frequently and damages have also increased following that trend.

Here are some statistics about damage in Vietnam caused by natural disasters from 2008-2012. (Lawson 2013) 
TABLE 4. Natural disasters in Vietnam 2008-2012 (Lawson 2013)

\begin{tabular}{|c|c|c|}
\hline Year & Disaster name & Damage \\
\hline 2008 & Typhoon & 60 people were dead \\
\hline 2009 & Typhoon Kistna & $\begin{array}{l}170000 \text { people were } \\
\text { displaced } \\
163 \text { people were dead } \\
\text { Over } 600 \text { were injured } \\
\$ 800 \text { million of damage to } \\
\text { agriculture,industry,poverty }\end{array}$ \\
\hline 2010 & Monsoon rains & 30 people were dead \\
\hline 2011 & Flood & $\begin{array}{l}185 \text { people were dead } \\
160000 \text { people were } \\
\text { displaced } \\
11000 \text { acres of rice fields } \\
\text { ruined } \\
\text { Ruined UNESCO World } \\
\text { heritage of Hoi An, Hue }\end{array}$ \\
\hline 2012 & Typhoon Tai-Kak & $\begin{array}{l}27 \text { people were dead } \\
12000 \text { were damaged } \\
56000 \text { acres of crops and } \\
\text { framed land ruined }\end{array}$ \\
\hline
\end{tabular}


As can be seen from the table, annually Vietnam is affected seriously by natural disasters which has caused huge damage to the country's economic development .This is also a factor which reduces people's living standard in Vietnam and has a negative impact on bank's business as well.

\section{International Environment}

From the opening age, Vietnam has integrated into the international business environment, in order to take advantage of domestic resources and attracting foreign investment, Vietnam joined organizations such as ASEAN, AFTA and WTO .Vietnam upholds diplomatic relations with 169 countries; signed bilateral and multilateral trade agreements with 80 countries; and exchanged prerogative with over 70 countries and territories, namely those with huge markets such as found in the US, Japan, EU and the newly industrialized economies of East Asia.

Especially since the time of joining the world trade organization WTO, many foreign investors in Vietnam with a total capital of up to hundreds of billions of dollars needing bank transactions has increased significantly. The cooperation of Vietnam companies with foreign companies has been strengthened. However, the entry has its own disadvantages. Typically, foreign companies are always with huge capital and high technology. This can be seen as a danger that domestic companies have to be wary. If national companies operate not appropriately, they will be at risk of bankruptcy due to the competition of foreign companies. (Staff 2012) 
Porter's five forces

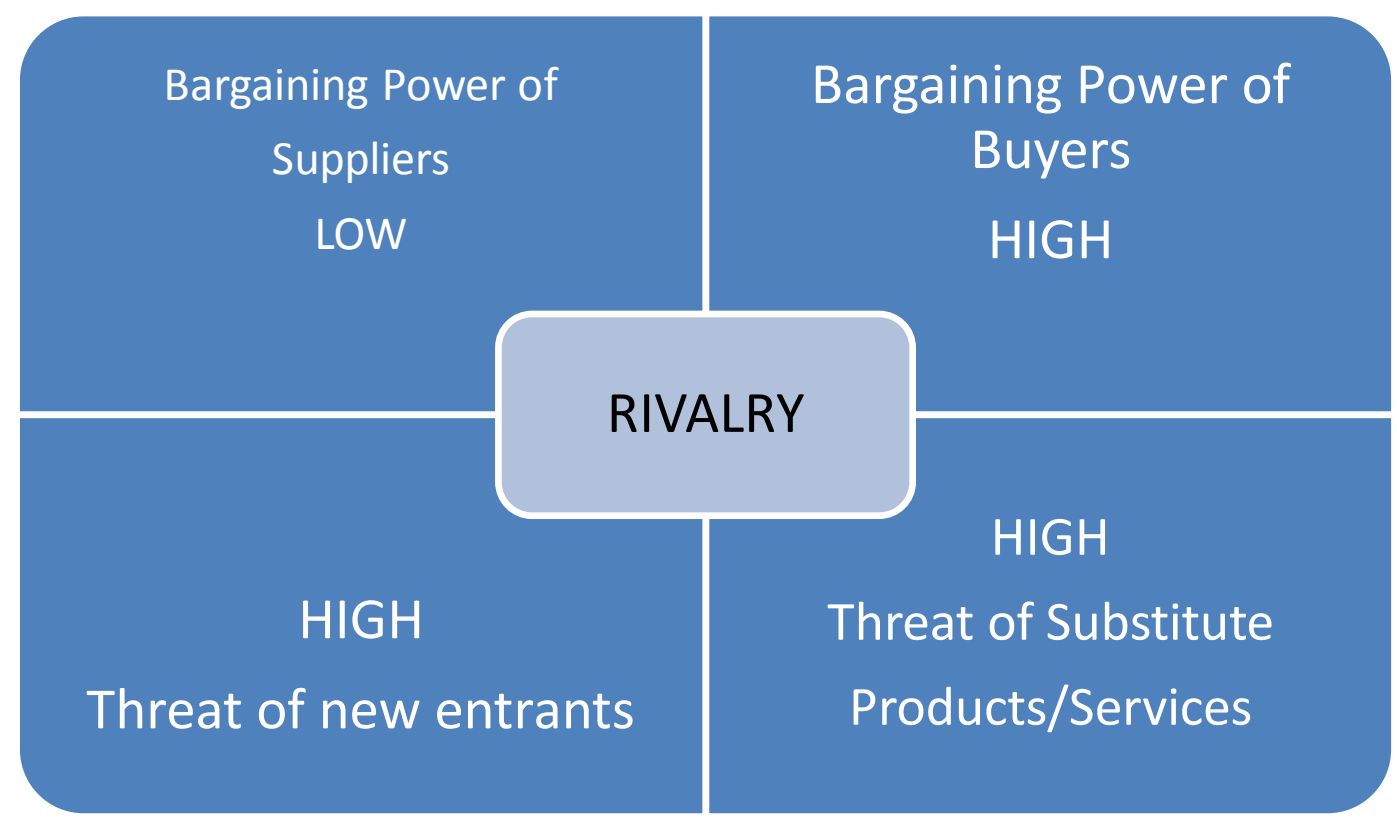

FIGURE 30. Porter's five forces (Staff 2012)

\section{Strength of clients}

Currently Sacombank is one of the most prestigious companies in Vietnam because of various products and services for customers. According to statistics, it has attracted more than 2 million customers. However, due to the fact that characteristics of the bank are sensitive to interest rates, this has a significant impact on the operation of Sacombank while the current interest rate situation is very complicated. Individuals and businesses will choose companies with lower interest rates and higher deposit rates for transactions thus Sacombank is competing with other companies to retain customers.

On the other hand, Sacombank has the advantage of quality service, mobilization and lending to customers .Sacombank always has a steady and stable customer quantity that are individual or small and medium entrepreneurships. As a consequence, when activities of accelerating foreign investment are stronger, transactions of Sacombank also grows dramatically. Besides, the bank also gives accretive deposit interest rates and promotions to raise funds from individuals and businesses. 


\section{Rival}

The banking sector is now the attractive field which takes much attention from domestic and foreign investment. Development prospects are also quite high. With the high growth rate of capital mobilization and loans in recent years, Sacombank is creating a distance away from other competitors in terms of total assets, deposits outstanding loans and profits.

The country nowadays has 101 banks, credit institutions and foreign operations. According to statistic, there are now 39 commercial banks and 14 banks with $100 \%$ foreign capital. This has created a fierce competition market in Vietnam. However, each bank has its own strengths and quality's services will affect SacomBank's operations correctly. (Nguyen 2012, 40)

Currently, together with the participation of various banks in Vietnamese market, domestic banks are not only competitive but also the link among banks in payment activities. The active links such as transferring money service from bank to other banks has supported each other through capital as shareholders of other banks by buying their securities. Partners of Sacombank will corporate comprehensively in various fields to share products and services. However, the link among banks in Vietnam is small, as indicated, a bank rarely take care of the crisis of other banking interest. There are many alliances in the cash payment and ATM card which still have not been implemented in many banks.

\section{Entry barriers}

The macro-regulation policies of government influence directly or indirectly a bank. When the state increases the reserve requirement ratio for banks, it can restrict the entry of certain credit institutions to invest in joint-stock commercial banks.

Currently, the government has also considered more strictly in giving operating permits for new banks. This has avoided the massive introduction of banks and changes in competition between banks which may affect the economy of Vietnam. Specifically, in 2008 there were nearly 10 banks which received operating permits, but so far only two banks are formally established in 2012. 


\section{Substitute products/ services}

In the past and even the future, volatility of the dollar exchange rate will affect the exchange rate and the development of the stock market. Besides, real estate in recent times has been obtained to attract a large number of investors in this field.

In addition, complicated movements of oil prices and gold prices in the world market also affect the domestic price of gold. Gold investment activity in Vietnam is now also somewhat limiting the savings and investments by individuals and businesses. This has caused trouble for banks which want to raise capital.

\subsubsection{SWOT analysis}

The SWOT analysis gathers both internal and external analyses' main ideas into a model which can quickly point out the strengthes, weakness as well as the opportunities and threats of the bank. 
TABLE 5. SWOT analysis (Nguyen 2012, 15)

\begin{tabular}{|c|c|}
\hline STRENGTHS & WEAKNESSES \\
\hline $\begin{array}{l}\text { - Product and service: diversity, richness. } \\
\text { - Dedicated employees, willing to learn } \\
\text { and have quick access. } \\
\text { - Modern techniques and facilities. } \\
\text { - Qualified executive }\end{array}$ & $\begin{array}{l}\text {-Professional qualifications of the } \\
\text { staff is not high. } \\
\text { - Marketing activities are weak. } \\
\text { - Science and technology are not } \\
\text { high. } \\
\text { - HR policies have not attracted } \\
\text { much talent }\end{array}$ \\
\hline OPPORTUNITIES & THREAT \\
\hline $\begin{array}{l}\text {-Economic and political stability. } \\
\text {-Attracting Foreign Investment } \\
\text { - Growth of the banking sector is higher } \\
\text { - International integration creates more } \\
\text { motivation to reform and develop banking } \\
\text { industry }\end{array}$ & $\begin{array}{l}\text {-New Companies appear } \\
\text { increasingly. } \\
\text { - The raising capital is in trouble } \\
\text { circumstance } \\
\text { - Many alternative service and } \\
\text { products. } \\
\text { - Foreign companies and companies } \\
\text { enter into Vietnam market with high } \\
\text { technology and capital }\end{array}$ \\
\hline
\end{tabular}


As the figure describes, Sacombank has taken advantage of its strong position in Vietnam's finance market because of the long time operation compared to others newly operating banks. This strong position comes from different factors: the richness and variety of products and services which are well performed by excellent staff and qualified excutives. Additionally, the physical evidencemodern facilities are also the strong point that Sacombank should maintain. However, there are still remaining some weaknesses which were analyzed from the internal and external environment of Sacombank. As mentioned above, Sacombank has qualified staff but there is still a big gap in qualifications among employees. Other weak points are strictly HR policies which make it hard for the bank to acttract new talents and old marketing strategy has also given Sacombank difficulties in fulfilling customers' needs and wants.

Economic and political stability makes up the first opportunity to Sacombank, Vietnam is well known as a peaceful country which attracts a large amount of FDI every year, especially in the service sector. Following the international integration in economic development of the whole economy, Sacombank has received lots of benefits. By contrast, because of the "well-rich" financial market opportunities bring back, there are many banks that compete directly or indirectly to Sacombank. Those banks can be domestic or even foreign banks which are larger in capital scale and "well-prepard"banking experiences.

Strengthes, Opportunities, Weaknesses and Threats always absolutely come in together. The best solution for the bank is continuing to increase strongpoints and exploit chances while enhancing weaknesses and avoding threats in most suitable ways.

\subsection{Marketing objective}

As for the bank's development strategy for the 2011-2020 period, Sacombank will energetically pursue the orientation " to be the first modern universal retail bank in the region", with strong concentration on efficiency and sustanability.The development strategy will focus on labour productivity enhancement, effective cost management, innovation of management methods and business process, maximization of value and benefits for customer . 
Sacombank has set seven groups of strategic objectives with proper adjustment in accordance with the actual situation.

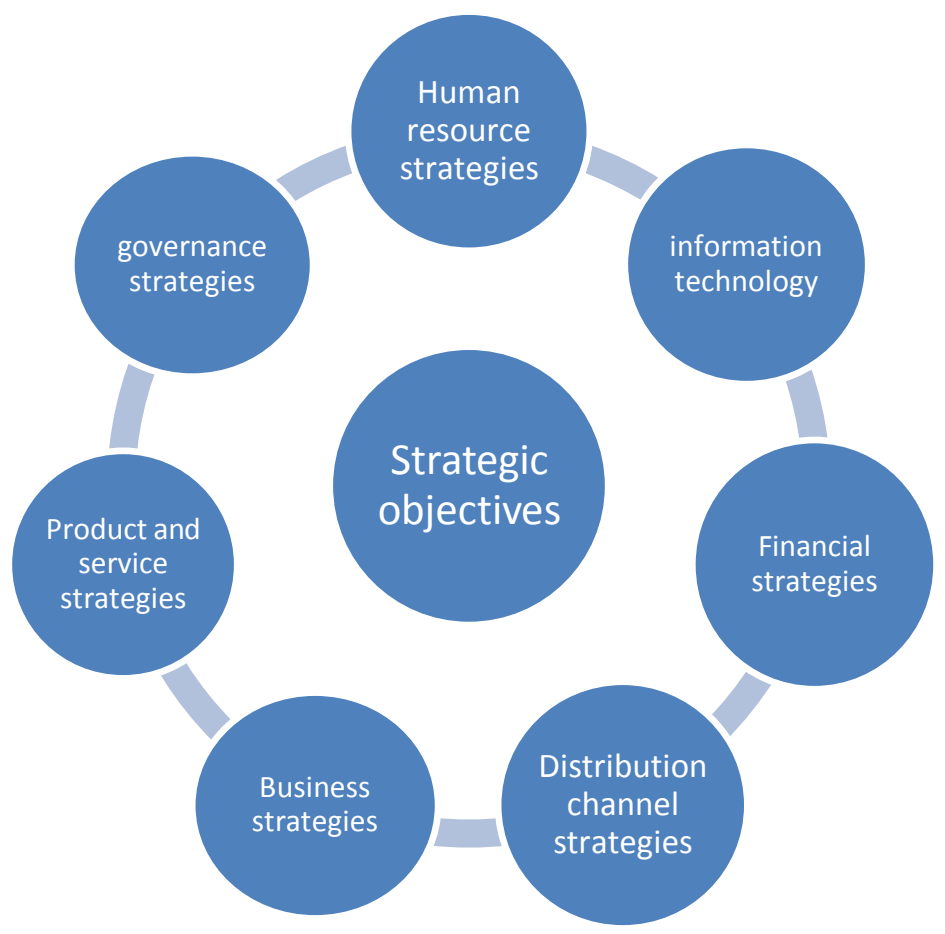

FIGURE 31. Strategic objectives (Vu 2011, 30-33)

Sacombank will increasingly enhance their image and position through developing brand, improving quality and efficiency of business. Creating innovation for organization, personnel and management mechanism as well as improving employee's productivity and selling skills is also taken into consideration. Besides, the bank modernizes banking technology with safe operation and efficient exploitation of the T24 computerization project. Modern management structure is in line with international practices. The most essential activity is accelerating the implementation procedure of data exploitation projects in support with business governance, risk management and effective resource allocation. Financial strategies will help the bank to develop a low risk and sustainable financial situation. Use of capital resource must be calculated regularly and effectively as well as restructure of the bank's asset liability portfolio to raise the percentage of profitable assets. In distribution channel, the bank will set strategies to gradually enhance the quality of existing network, especially transaction office. This is the key factor for the bank to access nearly to customers according to geographical segmentation. In business strategies, the bank will focus on retail activities and personal customers in order to ensure that 
each customer of Sacombank will at least use two services in the bank. Not only that, the bank will intensify diversification of various products/services with high technology and distinction in the market as well.Gorvernance strategies promote on the destruction of the bank's organization for efficiency. There will be a moderate model to governance from headquarters to each business location with improvement of speed and quality in management, checks, corrections and alerts. (Vu 2011, 30-33)

\subsection{Segmentation, target market and positioning}

This chapter will focus on the third important step of a marketing plan. By this step, segments will be clearly identified and targeted. After that, positioning part gives the idea of how the bank has created distinct impression in customers' mind.

\subsubsection{Segmentation}

Currently, Sacombank conducts market segmentation according to many criteria based on consumer segmentation. Because their business activities are mainly in Vietnam thus international segmentation or business segmentation will not be used in this situation. Besides, Sacombank also makes the combination of many criteria so that the customer can catch their image and brand effortlessly. After identifying and analyzing the market, Sacombank also make descriptions of some segments with full potentials. For example, some typical segmentations of Sacombank are:

- Geographic region (urban, rural, mountainous),

- Customer segmentation (individuals and enterprises)

- Size of business types (small and medium enterprises, large enterprises)

- Region (north, south...)....

Those segmentations generally can define what types of customers to target but only at a general level. Because of the fact that each segment also has smaller segments, the bank also needs to take these smaller segments into account as well. 
In this case, Sacombank should consider using VALS during the time of conducting segmentation strategies because of its useful and effective benefits in identifying smaller segments.

For example, instead of dividing just customers into enterprises and individual segments, VALS analysis helps the bank to define each segment in more detail, and customers should then be divided into 8 smaller segments:

Innovators: The bank should focus on consumers who have highest income, high self-esteem and image plays an important role in their life as an expression of taste, personality and indpendence.

Thinkers: customers that have also high income, which are motivated by ideas and are matured, responsible as well as professional.

Achivers: customers in the high resource group who are moderate, conventional, goal oriented and motivated by achivements

Experienced customers who are energetic, impulsive, enthusiastic and motivated by self expression

Believer: customers who are in low resource group and predictable; Familiar services should be concentrated on this segment.

Strivers: the low resource group who are also motivated by achievements but have fewer economic, social, and psychological resources than achivers.

Markers: opposited with them. Makers tend to choose basic service rather than expensive service.

Suvivors: customers who are powerless, burdened, conservative and have the lowest income. They are careful consumers and also loyal to their favorite brand..

\subsubsection{Target market}

After identifying and analyzing each segment, the bank has made the determination of target market. Those are segmentations based on customers including personal customers and small and medium enterprises. 
- Private Clients are classified into:

Individual customers are middle-income, stable with an average age of 30 years old, individuals concentrated in large urban areas with demand for banking services such as savings, loans target user and business ... The bank will also pay special attention to high-value segment of the upper class with the priority banking services and investment banking services.

- Small and medium enterprises (SMEs): The active ingredient in the economic business sector which are dynamic and effective in industrial production, personal services and community recreation services...

Besides, traditional customers are small and medium enterprises; Sacombank also expands their major clientele to big corporations. In spite of the fact that Sacombank nowadays specializes their target market based on selections and criteria in which they only focus on two or more segment markets that have potential to make their business effective, they also try to spread their business activities in the entire market to gain more profit. Although it is a risk strategy to conduct it, Sacombank now has been developing as one of the biggest commercial banks in Vietnam and they have sufficient capabilities to conduct them. (Nguyen 2012, 39)

\subsubsection{Positioning}

After identifying the target market, Sacombank has focused on planning strategies which will create a distinct impression in customers' mind. They have identified and communicated a brand's uniqueness, differentiation and verifiable value. It is the way Sacombank make their products/service different from each other. On the other hand, evaluating competitors in the market also helps them to have a clear view of market situation nowadays so that they can make a proper positioning strategy. Sacombank has always concentrated on some particular types of positioning approach in building branch's success which are illustrated in the following figure. 


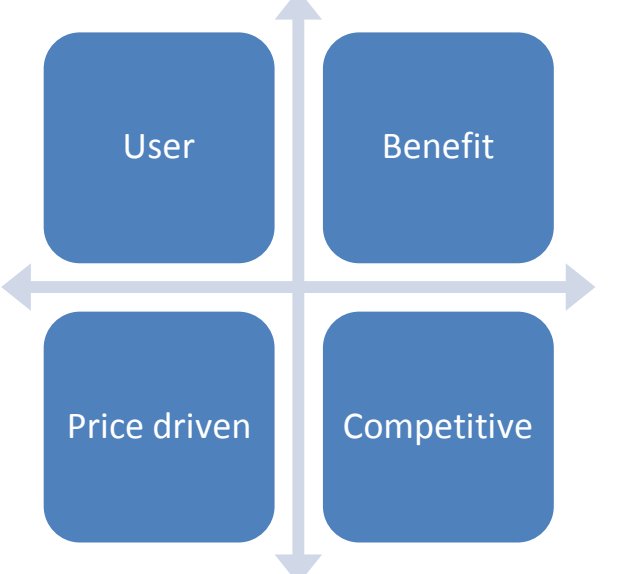

FIGURE 32. Positioning approach (Nguyen 2012, 32)

As the figure presents, user is one of typical type of positioning approach that Sacombank has applied. In user type, the bank need to focus on specifying user or type of customer while as benefit positioning is often used when the bank has realized their superior benefit of services/products relative to other competitors. In such highly competitive market like banking and financial sectors, the bank also needs to try to develop their brand by comparing their benefits directly to those offered by other ones. And the last one is price driven that the bank can use to attract more customers with their low price policies such as low interest rate, low fee for financial advice... Definitely, those positioning approach will help the bank to create superior benefits of the brand to target customers as well as establishing a strong position in the market.

The proper positioning strategy is highly evaluated that the bank shoud utilize because of its effectiveness in choosing which values of services to be set in customers'mind. 
3.5 Marketing mix strategies

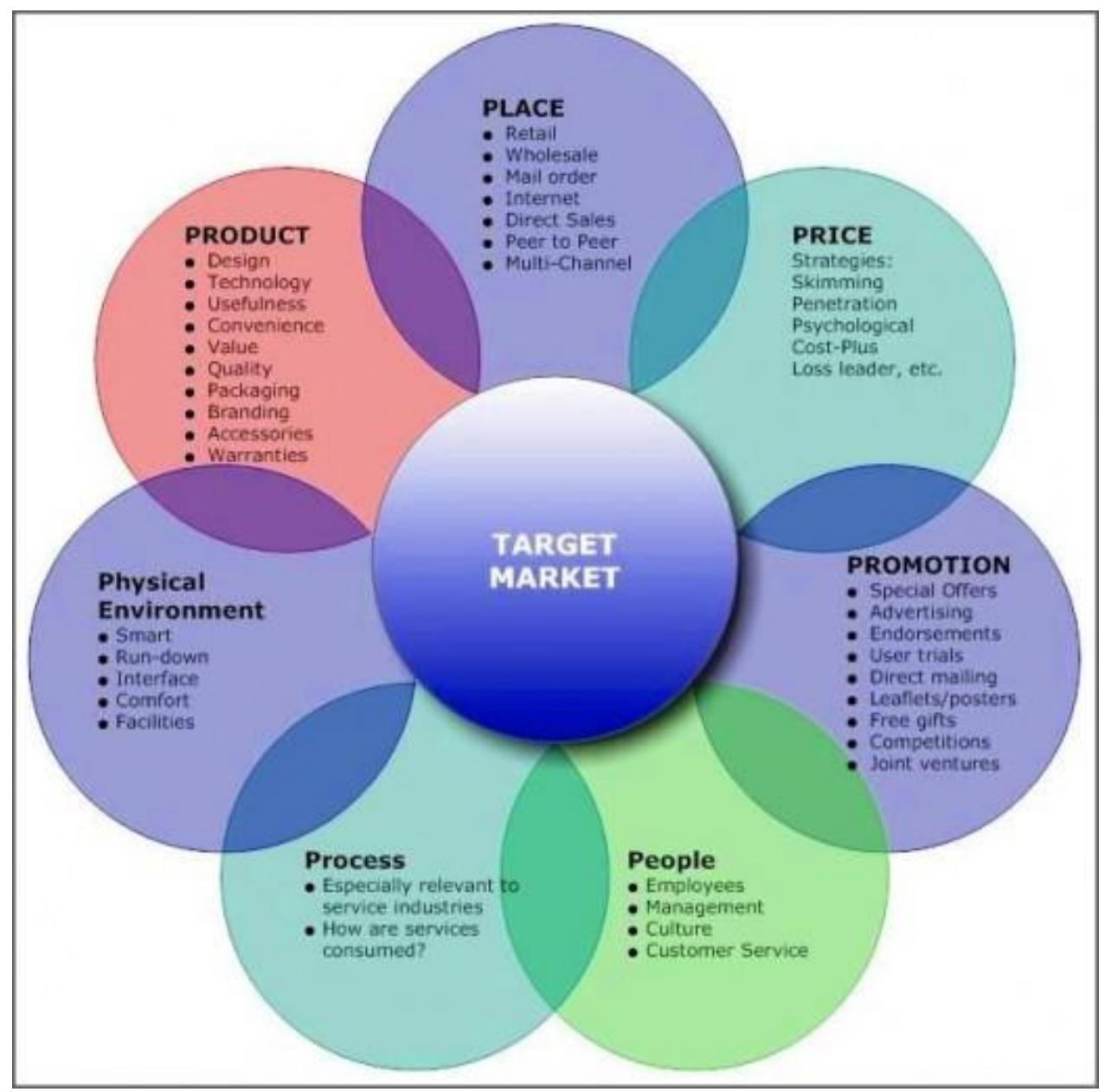

FIGURE 33. Marketing mix 7P (Nguyen 2012, 34)

7Ps marketing mix is well known for a set of controllable variables composed of product, place, price, promotion, people, process, physical evidence that the bank will assemble to satisfy their target customers. Whereas, services/products of the bank must adapt to the needs and wants of customers about design, technology, convenience, usefulness, value, packaging, branding. In addition, distribution channels must make products/service conveniently available to the target market...

This part will cover marketing mix strategies 7Ps in Sacombank which consists of current strategies that the bank has implemented and some suggested strategies which may help to improve the bank's image. 


\subsubsection{Product}

In addition to traditional services, nowadays in the market mechanism and under the fierce competitive environment, companies are increasingly diversifying their products. Sacombank is no exception to this general trend .Products/ services must serve the objective of maximizing use of products/ services by customers and they also have to be designed with multi utility features in order to increase using frequency by customers. Not only that, products/services of Sacombank must be unique and distinctive to improve bank's competitiveness in the market. (Vu 2011, 42)

With the diversification of strategies and oriented products to customers' demand, currently Sacombank has supplied various products on the market including deposit, saving and other products like credit cards or foreign exchange transactions. Better service is more important than just a good product in the marketing of banking service. Therefore, the concentration must be the demand of satisfaction for that product or service.Some typical products/services in Sacombank will be interpreted below:

Deposits: Wide variety of deposits are offered to adapt customer's demand. Fixed deposits are safe, flexible, liquidable and returnable.Those can be seen as a combination of unbeatable features of fixed deposits from Sacombank.whereas, recurring deposits help customers to invest a small amount of money every month and finally it ends up with a huge saving on maturity.

Saving accounts: Sacombank can also offer a power packaged saving account with a host of convenient features and distribution channel to get transaction through.

Besides, the bank needs to enhance convienences among network branchs and ATM system as well as facility of E channel like internet banking or mobile banking.

\section{Suggested strategies}


Besides current strategies that Sacombank has conducted, there will be some additional product strategies that may help them to enhance quality, convenience and value of their products/services.

- Concentraing in building a strategic plan to launch new and unique products that have never been in the market which entirely satisfy target customers.

- The management of services/products and orientations in developing products/services both in quatity and quality need to take into consideration carefully.

- Identifying incentive policies and new products to adapt fully customers' demands, decreasing the complexity of procurement when transactions take place between customers and the bank.

- Continuing to improve and complete quality of current products and develop more effective functions for them.

\subsubsection{Pricing policy}

Prices in banking business relate to interest rates, loan and other costs for use of the bank's capital.The pricing policy is considered essential for raising the number of customers in the bank. The quality of service offered also has the direct relationship with fees charged. Hences, customer service is the most important factor when taking into account this kind of policy. Moreover, Sacombank has devided this into two fold strategies in which the first one including interest and fee charge while interest paid is belonged to the second strategy.Here is the table of deposit rate and interest rate that Sacombank has applied in order to have a competitive position in the market. 
TABLE 6. Sacombank deposit rate (Tran 2012, 14)

\begin{tabular}{|l|l|l|l|}
\hline Term & $\begin{array}{l}\text { VND } \\
(\% / \text { Uear }\end{array}$ & $\begin{array}{l}\text { USD } \\
(\% / \text { year })\end{array}$ & $\begin{array}{l}\text { EUR } \\
(\% / \text { year })\end{array}$ \\
\hline No term & 3.60 & 1.50 & 1.00 \\
\hline 01 month & 12.00 & 6.00 & 3.00 \\
\hline 02 months & 12.00 & 6.00 & 3.00 \\
\hline 03 months & 12.00 & 6.00 & 2.90 \\
\hline 06 months & 12.00 & 6.00 & 2.90 \\
\hline 07 months & 12.00 & - & - \\
\hline 09 months & 12.00 & 6.00 & 2.91 \\
\hline 12 months & 12.00 & 6.00 & 2.70 \\
\hline 13 months & 12.00 & - & - \\
\hline 15 months & 12.00 & - & - \\
\hline 18 months & 11.90 & 5.80 & 2.70 \\
\hline 24 months & 11.87 & 5.57 & 2.70 \\
\hline
\end{tabular}

Unlike state-owned banks, Sacombank is always flexible in interest rates, in line with market development. In recent years, Sacombank has continuously raised capital and it is also evaluated as one of Vietnamese banks with the highest interest rate. In 2012, Sacombank interest rate was up to $12 \%$ / year for the period from 1 to 12 months. 


\begin{tabular}{|c|c|c|c|c|c|c|c|c|c|}
\hline \multirow[t]{2}{*}{ Customer } & \multirow[t]{2}{*}{ Asset } & \multicolumn{2}{|c|}{6 months } & \multicolumn{2}{|c|}{$\begin{array}{l}\text { From } 6 \\
\text { until } 12 \\
\text { months }\end{array}$} & \multicolumn{2}{|c|}{$\begin{array}{l}\text { Medium } \\
\text { terms }\end{array}$} & \multicolumn{2}{|c|}{$\begin{array}{l}\text { Long } \\
\text { terms }\end{array}$} \\
\hline & & $\begin{array}{c}\text { Interest } \\
\text { rate }\end{array}$ & Fee & $\begin{array}{c}\text { Interest } \\
\text { rate }\end{array}$ & Fee & $\begin{array}{c}\text { Interest } \\
\text { rate }\end{array}$ & Fee & $\begin{array}{c}\text { Interst } \\
\text { rate }\end{array}$ & Fee \\
\hline \multirow{2}{*}{ Individual } & $\begin{array}{l}\text { Real } \\
\text { estate }\end{array}$ & 1.17 & 1.50 & 1.22 & 2.50 & 1.22 & $\begin{array}{l}3.5 \\
0\end{array}$ & 1.27 & 4.50 \\
\hline & $\begin{array}{l}\text { Other } \\
\text { assets }\end{array}$ & 1.22 & 1.50 & 1.27 & 2.50 & 1.27 & $\begin{array}{l}3.5 \\
0\end{array}$ & 1.32 & 4.50 \\
\hline \multirow{2}{*}{$\begin{array}{l}\text { Enterprise } \\
\text { ( no } \\
\text { goodwill) }\end{array}$} & $\begin{array}{l}\text { Real } \\
\text { estate }\end{array}$ & 1.15 & 1.50 & 1.20 & 2.50 & 1.27 & $\begin{array}{l}3.5 \\
0\end{array}$ & 1.37 & 4.50 \\
\hline & $\begin{array}{l}\text { Other } \\
\text { assets }\end{array}$ & 1.20 & 1.50 & 1.25 & 2.50 & 1.42 & $\begin{array}{l}3.5 \\
0\end{array}$ & 1.42 & 4.50 \\
\hline \multirow{2}{*}{$\begin{array}{l}\text { Enterprise } \\
\text { (goodwill) }\end{array}$} & $\begin{array}{l}\text { Real } \\
\text { estate }\end{array}$ & 1.12 & 1.50 & 1.17 & 2.50 & 1.27 & $\begin{array}{l}3.5 \\
0\end{array}$ & 1.27 & 4.50 \\
\hline & $\begin{array}{l}\text { Other } \\
\text { assets }\end{array}$ & 1.17 & 1.50 & 1.22 & 2.50 & 1.42 & $\begin{array}{l}3.5 \\
0\end{array}$ & 1.52 & 4.50 \\
\hline
\end{tabular}

The interest rate is a very sensitive element which always fluctuates in the market. Interest rates greatly affect business activities of the bank since it is a key factor to decide whether customers use products and services of the bank or not.

Identifying the importance of interest rates, in the near future, Sacombank has to make good interest rate policy, which means classifying and evaluating customer. Sacombank can also apply interest rates for specific client groups and takes into consideration the sensitivity of customer groups to set fees and interest rates.For less sensitive groups, the bank may impose higher interest rates, fees, and vice versa. 


\section{Suggested strategies:}

Recognizing the importance of this policy, Sacombank should try to implement various combinations of pricing strategies in order to retain existing customers and attract new customers.

In order to have a flexible price which is suitable to customers' demands, Sacombank should take into account those factors which directly impact on their pricing decisions.

- The living cycle of products in the market.

- Target customers that services/ products are aimed to served (Usually, the bank need to consider income level of customers that have been analyzed in the segmentation of the bank).

- Pricing level of other competitive banks in the market.This is a crucial factor that Sacombank should examine due to the fact that there are similarities in products/services of all Vietnamese banks. From that, Sacombank should conduct a flexible pricing policy together with constructing an incentive policy which is more prominent than any other banks in the market.

\subsubsection{Distribution}

This is one of the most important policies of banking service. The network is a distribution channel which is indispensable not only in creating brand but also in increasing the accessibility of products and services for customers. Recognizing that, Sacombank has always expanded their network to access more instantly to customers. Based on technology capability, it is possible to split the bank's distribution channels into two categories. 


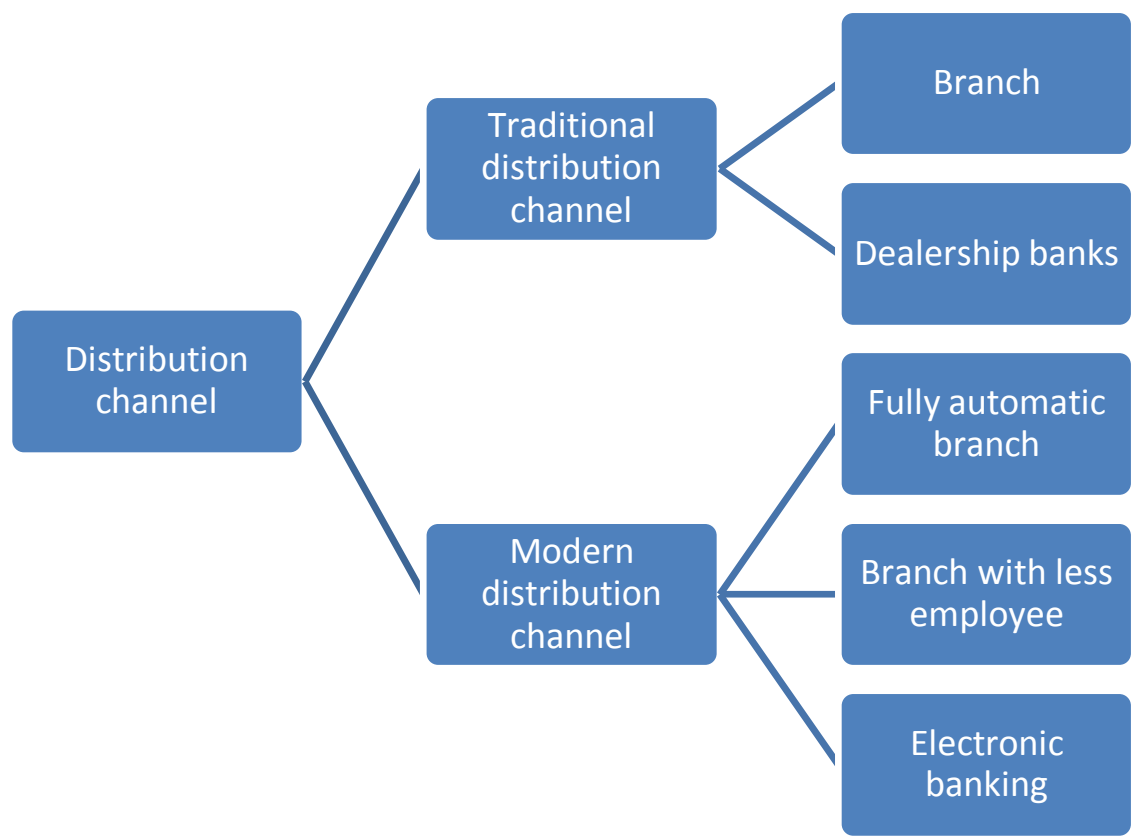

FIGURE 34. Distribution channel (Nguyen 2012, 35-39)

As the figure illustrates, traditional distribution channel is debuted with the advent of the bank, mainly based on activities of direct staff. It includes:

\section{Traditional distribution channels}

Branch: A type of traditional channels associated with the headquarter system and facilities in certain locations. Currently, the bank is trying to expand its network across the country and even internationally.

Dealership Companies: Bank through a bank can locate in a based business as a professional agent of any other bank or as commission payment agents, money transfer agents, traveler's checks...

\section{Modern distribution channels}

The system of modern distribution channels is appeared on the basis of scientific and technical progress. In particular, the application of information technology in banking sector includes following channels:

- Fully automated branches: they are fully implemented by machines under the control of electronic devices. 
- Branches with less employees: they are consistent with customers and lower costs.

- Electronic Banking (E - Banking): A banking model allows customers in remote area to access to the bank with main activities such as collecting information, performing payment transactions, using new products and services. Electronic transactions made through electronic media transactions include payment machine at the point of sale, automated teller machines, telephone banking, financial supermarkets, and online banking...

When science and technology have dramatically developed, modern distribution channels are also increasing and replacing traditional distribution channels. The emergence of modern distribution channels is to make banking executives feel interested in a mixture of multiple distribution channels rather than choosing a single distribution channel. (Shodhganga 2009)

Network operations of Sacombank has developed dramatically. In 2012, Sacombank officially opened and put into operation 8 business locations, raising the total number of business locations to 316. They haved been presented in 48 out of 63 provinces of Vietnam and in three neighboring countries. In general, the network development task was well prepared and implemented on schedule.

In parallel with establishment of new business locations, the bank also has plans to improve the performance of its exiting transactions. Accordingly, the bank has made in-depth analysis and conducted various solutions to innovate their resources.

\section{Suggested strategies}

Addition to current distribution strategies, here are some recommendations that Sacombank may consult when making decisions about distrbition channels.

- Network development is not only in central cities, but also in rural regions and remote areas. In those area, the population has large demand for banking products /services that have not been met sufficiently and many joint stock commercial banks still have not appeared yet in those area. Hence the bank should exploit the potential of those markets in the future. 
- ATM machines should be distributed nationwide with various functions that can enhance utilities for customers.

- Payment functions in supermarkets, restaurants, shopping mall....should be invested more to create convinence and quickness for customers.

- Improving the condition of exiting transaction offices by equipping modern technology and facilities with good location.

\subsubsection{Promotion}

Promotion of Sacombank has made progress significantly, and the brand image of Sacombank constantly has brought enormous efficiency.

Communication activities - promotion include:

- Advertising: Sacombank uses all forms of advertising in the mass media: newspapers, electronic media, television, banners, and printed brochures...

- Personal exchange: This is the process of transactions between employees directly with customers. In this operation, staff role is "the face of banking". Sacombank has been quite successful as a young staff with uniform appearance, highly qualified and very enthusiastic spirit.

- Promotional activities: Sacombank has various promotions such as"Loi Cam On", "An Toan moi ngay, nhan ngay qua tang" ... Besides, they also donate helmets, rain gear, personal umbrella....to customers in special occasions. In the area of funding, it shall increase the deposit rates, with promotions such as "saving for millionaires"... Those promotions have been a hit for customers currently.

- Direct marketing Activities: Sacombank annually held customer conference in order to introduce banking products, old year's review and New Year's direction. They also organize workshops to advice and support customers to attract lot of attention from publicity. 
- Sponsorship: Sacombank has sponsored variety of TV programs and extensive social activities such as "Stock learning", "Financial news"... Especially from 16$18 / 11 / 2007$, Sacombank honored as gold sponsors for the summit on business and investment 5th ASEAN (ASEAN BIS 2007) in Singapore and until now, this is the sole time that Vietnam has funded for this kind of conference. (Vu 2011, 52)

Besides, Sacombank also constantly promotes charitable activities: walking charity, supporting Agent Orange victims, children with disabilities ...the following table will describe clearly about Sacombank's community activities.

TABLE 8. Sacombank's programs (Tran 2012, 18)

\begin{tabular}{|c|c|c|}
\hline No. & Programs & Amount \\
\hline 1 & $\begin{array}{l}\text { Sacombank scholarship " Nurturing Dream” } \\
2003\end{array}$ & $3,772,950,000$ \\
\hline 2 & "Running for Community health" 2004 & $7,620,000,000$ \\
\hline 3 & $\begin{array}{l}\text { Charity program welcoming the New Year of } \\
\text { the snake } 2013\end{array}$ & $4,316,000,000$ \\
\hline 4 & Stone bench donation & $1,677,860,000$ \\
\hline 4 & $\begin{array}{l}\text { Care for employees 'living conditions (march } \\
8^{\text {th }} \text {, support for needy employees' family...) }\end{array}$ & $2,615,708,000$ \\
\hline Total & & $20,002,518,000$ \\
\hline
\end{tabular}

All the community development strategies of Sacombank are based on the target of supporting vulnerable people in society, making a contribution in enhancing equality and its corporate social responsibilities.

\section{Suggested strategies}

As can be seen above, currently Sacombank has thoroughly exploit variety of promotion activities that help to improve the bank's image. Besides those 
activities, the bank should also concern in the trend of society to keep pace with and have strategic promotion plans.

- Accelerating promotional activities is a good way to attract customers.

- Not only advertsing take places in traditional channel like TV, newspaper, magazine.... but also the bank should enhance advertising in internet which is increasingly indespensble in Vietnamese people life.

- Besides internet banking, mobile banking should also be concerned.Various apps supported by mobiles should be launched and developed to catch up with the modern techonology development nowadays.

- Broadnening and developing services of supporting and consulting customers through different channels such as Chat voice, SMS, Facebook... so that the bank can know oppinions from customers and on that basis, improving their weaknesses as well as exploiting their advantages and potentials.

\subsubsection{Human resources}

Since human perception is a deciding factor, Sacombank leadership has conducted a strategic human resource management to create innovative working environment and dynamic profession with preferential policies and satisfactory treatment. Therefore, they can facilitate maximum staff encouragement and promote activities with all abilities. The staff and employees have university degrees and postgraduate accounting for $89 \%$ of the total number of officers and employees whereas colleges and other degree is $11 \%$. Sacombank also has a management staff with excelent capacity, qualifications and experience in banking operations. (Tran 2012, 20)

Sacombank has always focused on training and retraining employees. Staffs have many opportunities to study and improve their professional skills. They have realized that customer base is fundamental to all operations. In addition to internal training, the bank has organized many training courses outside the state and invited international experts to enhance employee's professional skills which can respond promptly banking activities in terms of integration. Last year, the bank 
has organized 1663 training courses in which 142 managers participated in and were certified as branch director by the Netherlands Institute for Banking, Insurance and Investment. With the training budget of VND 15 billion per year, those training courses are one of the most important programs in boosting employee's quality of the bank. Not only that, Sacombank has organized online training programs with four main features like learning and testing on computer connecting with the bank system, forum to discuss studied topics in order to support staff despite of geographical obstacles. Last but not least, the bank also collaborates with domestic and foreign universities to make a research about training programs. Currently, the bank has completed 21 specified textbooks for training activities. (Tran 2012, 23-24)

\section{Suggested strategies}

Sacombank can also conduct various plans assessing human resource criteria such as capacity, integration capabilities, and effectiveness. Some of those plans are given below.

- Classifying and evaluating staff by various professional capacities in order to assign work and make it efficient.

- Training for all staff with various skills in order when communicating with clients, they can make a good impression and trust for customers.

- Always having a policy "to attract and retain talent" in many ways: with attractive salary, good remuneration as well as creating a friendly working environment.

- Regularly training highly qualified staff can make seeds for the leading division.

- There should be a justice in payoffs to employees in order for them to be aware of the importance of job so that they can promote love, passionate for work.

- Organizing contests so that there will be further promotion of the professional level of officials and employees. 
- Training, enhancing specialized knowledge in a number of important business: accounting, international payments, credit...

In addition to the selection of personnel of qualified employees, the bank recruitment should focus on image of staff to create the image of a young beautiful, dynamic, qualified bank.

\subsubsection{Process}

Process is the way of giving services and the attitude of people delivering it. Process plays an important role in raising customer's satisfaction. Factors such as waiting time, quality of service, adaptation, willingness and helpfulness of employees to customers are also increasing crucial nowadays. In order to conduct process strategies more effectively, Sacombank takes into considerations all factors relating to.

The first important factor is the flow of activity in Sacombank. In Sacombank, various functions are segregated .Separated counters have clear indication. Thus customers do not make any mistake among those. This makes procedures simple and customers do not have to consume much time.

Next is the standardization. Actually, all banks have their own standardization. This is because of the regulation they are subjected to. They also have standard documentation and standard form which helps to save a lot of time behind individual transactions.

Additionally, simplicity is also taken into consideration and the number of steps are always specified and a specific pattern is followed to reduce time taken.

\section{Suggested strategies}

In the future, Sacombank should aggressively upgrade technology and sciences to adapt to customer's requirements. Not only that, the bank should organize many training courses to supply more friendly attitude, knowledge and skills to employees. Thus, they can solve all problems or requirements that customers have immediately without waiting. Futhermore, there have to be sufficient employees 
in customer service placement so that whenever a customer has a phone call directly to the bank, they do not have to stay on hold for several minutes listening to a recorded message before they get through.

- Services/products of the bank will be appreciated highly if they are conducted in a perfect way. If there are some arising matters during transactions, they have to be limited in a maximized way. Hence, the bank should rigorously control customers' information to prevent risks during the process.

\subsubsection{Physical evidence}

Physical evidence is the overall layout of Sacombank which refers to the design of Sacombank's places. It relates to all factors that make the process easier and smoothier. In Sacombank, the physical evidence normally is the placement of customer service, executive's desk or the location of a place for dispositing a cheque. Process strategies will help the bank to create and enhance customers' impression and satisfaction with the overall procedure involving the services offered by the bank. Hence, Sacombank has always paid full attention in physical evidence.

Usually, customer service's placement is especially outstanding in the office which remarkably attracts customers from the first time. Those places are designed with pleasant colors together with the symbol of Sacombank. Not only that, the environment is spacious with the harmonious layout of tables, stands, chairs....Flowers are also the significant points in every placement of customer service. Additionally, Sacombank also tries to create an overwhelming atmosphere of friendliness.The places are always kept in clean and tidy including safe conditions with modern technology and devices.

Last but not least, the web page of the bank also has to be taken into account carefully. The information there is always updated and has an easy interface to access. The bank gives pens and writing pads to internal customers, and even the passbooks, chequebooks...to reduce the inherent intangibility of services. Sacombank believes that it is a good way to impact on customers' impression.

\section{Suggested strategies}


Besides those current physical evidence strategies, here are some suggested strategies that the bank may take into consideration.

- The bank should also engage their customer and ask for feedback so that they can develop reference materials. It is a good strategy for them improve their brand's loyalty as well as creating attraction potential customers.

- Equipping modern facilities and technology with various functions to adapt to customers' demands.

- Using internet with fast speed so that transaction can take place conveniently and quickly.

- Regularly checking and taking care of ATM machines or POS in order to ensure that those machines are always active 24/7 with sufficient money and full functions. 


\section{CONCLUSIONS}

The thesis is written to provide a bank marketing strategy for Sacombank. In order to achieve this main objective, theoretical framework for service marketing has been implemented which includes various analyses: SWOT, Pestel, Porter's 5 forces and marketing mix strategy... Correspondingly, the current situation of the case bank analysis has been done so that the authors can easily compare, evaluate and suggest solutions for the bank marketing strategy.

In recent years, Sacombank is one of the banks that have achieved great success in the market. However, due to the flunctuating financial market in Vietnam, customers can easily change their trusted brand, alter services they are using. Analyzing and finding a strategic marketing plan for the bank's situation is extremely important to every marketer, especially the approach at strategic level (this thesis's objectives) before considering the operational plan.

Although the thesis still has many limitations, the Authors hope that it can be a reference research for those students who are interested in the bank marketing field and its "highly applied" characteristic in real situation. 


\section{REFERENCES}

\section{Published references}

Blythe, J. 2006. Principles \& Practice of Marketing. Cengage Learning EMEA.

Böhm, A. 2009. The SWOT analysis. GRIN Verlag.

Crowther, D \& Lancaster, G . 2009. Research method: A Concise Introduction to Research in Management and Business Consultancy. Butterworth-Heinemann.

Dibb, S \& Simkin, L. 1996. The Marketing Planning Workbook: Effective Marketing for Marketing Managers. Cengage Learning EMEA.

Donovan., Robert, J., Rossiter. \& John, R. 1982. Store atmosphere: An environmental Psychology approach. Journal of retailing. 30-34

Fifield, P. 2012. Marketing strategy. Third edition. Routledge.

Frankel, R \& Devers, J . 2000. Study Design in Qualitative Research. Second edition.. Education for Health.

Ferrell, P \& Hartline, D. 2010. Marketing Strategy. Cengage Learning.

Gelder, D \& Woodcock, P . 2003. Marketing and promotional strategy. Nelson Thornes Goldstein. 2007. What is Customer Segmentation?. Apsen Publishers Online

Gupta. 2005. Managing Customers as Investments. Pearson Education

Kotler, P \& Keller, K. 2006. Marketing Management. Prentice Hall.

Kotler, P \& Gary, A. 2010. principles of Marketing. Pearson Education.

Kotler, P. 2000. Kotler on Marketing : How to Create, Win, and Dominate market. Simon and Schuster.

Kotler, P. 2010. Marketing management. Pearson Education

Lovelock, C \& Wright, L. 2001. Principle of Service marketing and Management. Prentice Hall.

Middleton, V. 2009. Marketing in Travel and Tourism. Routledge. 
Monroe, B. 2003. The Pricing Strategy Audit. Cambridge Strategy Publications.

Porter, M. 1985. Competitive Advantage: Creating and Sustaining Superior Performance. New york.

Quinn, J. 1980. Strategies for Change: Logical Incrementalism. R.D. Irwin.

Roger, K, Steven, H, William, R \& Erin, S. 2012. Marketing: The Core. McGraw-Hill Education

Stephen, B. 1992. Service Quality: Multidisciplinary and Multinational Perspectives. Lexington Books.

Srinivasan, R. 2012. services marketing: the Indian context. PHI Learning Pvt. Ltd.

Thomas.J. 2001. Master Planing of Marketing. Prentice Hall.

Uppal, K. 2009. "Marketing of bank product." International Journal of Management Research (JMIJMR).

Uppal, K . 2009. marketing of bank product-emerging challenges and strategies. International journal of managemnet research.

Wood, M. 2011. The Marketing Plan Handbook.. Prentice Hall: New Jersey.

Yankelovich, D \& Meer, D. 2006. Rediscovering Market Segmentation. Harvad Business review 


\section{Unpublished References}

Hoang, Q. 2011. Financial Markets in Vietnam's Transition Economy: Facts, Insights, Implications. HoChiMinh Univerisity of Economics.

Nguyen, N. 2012. Marketing strategies for Sacombank. HoChiMinh city.

Tran, V. 2012. Sacombank's statistics. HochiMinh city. Brochure

Vu, H. 2011. Sacombank's analysis. HochinMinh city. Brochure 


\section{Electronic sources}

Adillawa. 2011. Role of marketing in banking.[referenced 27 October 2013]. Available in sribd database:

http://vi.scribd.com/doc/26047161/Role-of-Marketing-in-Banking.

Arpit. 2011. Arpit Srivastava's Blog. [referenced 23 October 2013]. Available at: :

http://arpitsrivastava.wordpress.com/2011/09/26/core-concepts-of-marketing-philipkotler-summary/.

Assess current position. 2013. [referenced 23 October 2013].Available at: http://www.strategicplantool.com/Assess_Current_Position.htm.

Banking Leaders Discuss 2014 Strategic Planning Priorities. 2013. [referenced 23 October 2013]. Available in blogspot.fi database:

http://jimmarous.blogspot.fi/2013/07/banking-credit-union-2014-strategic-planningpriorities.html.

Choice of consumer segmentation base. 2008. [referenced 23 October 2013]. Availablle at:

http://www.segmentationstudyguide.com/segmentation-bases/choice-of-segmentationbases/.

E learning session. 2008. [referenced 23 October 2013]. Available at: : http://highered.mcgrawhill.com/sites/0256133603/student_view0/chapter8/elearning_sessions.html.

Four step market segmentation. 2009. [referenced 24 October 2013] Available at: : http://marketing717.blogspot.fi/2009/03/four-step-market-segmentation-process.html.

Human resources organizational development.2010. [referenced 23 October 2013]. Available at: :

https://www.53.com/careers/human_resources_organizational_development.html. Inflation rate.2012. [referenced 25 October 2013]. Available at: : http://www.gso.gov.vn/default_en.aspx?tabid=491. 
Lawson, Mark. 2013. Vietnam floods: 2008 to 2012. [referenced 15 October 2013].

Available at: :

http://floodlist.com/asia/vietnam-2008-2012.

Lesson physical evidence. 2011. [referenced 23 October 2013]. Availble at:

http://www.marketingteacher.com/lesson-store/lesson-physical-evidence.html.

Market analysis. 2010. [referenced 23 October 2013]. Available at: :

http://toolkit.smallbiz.nsw.gov.au/part/3/10/49.

Marketing plan.2009. [referenced 23 October 2013]. Available at: :

http://www.rbcroyalbank.com/RBC:-/sme/bigidea/marketing.html.

Marketing situation.2010. [referenced 23 October 2013]. Avalable at:

http://www.netmba.com/marketing/situation/.

Marketing therories pestel analysis. 2009. [referenced 23 October 2013]. Available at: : http://www.professionalacademy.com/news/marketing-theories-pestel-analysis.

Neil. 2012. 3 main activities target marketing. [referenced 12 October 2013]. Available at: :

http://smallbusiness.chron.com/3-main-activities-target-marketing-22582.html.

Neili, J. 2007. Qualitative versus Quantitative Research: Key points in a classic debate. [referenced 4 October 2013]. Available at: :

http://wilderdom.com/research/QualitativeVersusQuantitativeResearch.html.

Pest market analysis tool.2010. [referenced 2 October 2013]. Available at: :

http://www.businessballs.com/pestanalysisfreetemplate.htm.

Pestel analysis: business environmental analysis. 2008. [referenced 6 October

2013].Available at: :

http://pestleanalysis.com/pestle-analysis-business-environmental-analysis/.

Pestel analysis. 2010. [referenced 13 October 2013]Available at: :

http://www.cipd.co.uk/hr-resources/factsheets/pestle-analysis.aspx. 
Porter's value chain. 2013. [referenced 14 October 2013]. Available at: :

http://www.ifm.eng.cam.ac.uk/research/dstools/value-chain-/.

Posts, Atom \&Toim. 2006. Qualitative and Quantitative research design. [referenced 22 October 2013]. Available at: :

http://dissertationhelponline.blogspot.fi/2011_06_01_archive.html.

Quantitative and qualitative research. 2012. [referenced 14 October 2013]Available at: : http://www.mymarketresearchmethods.com/quantitative-vs-qualitative-research-whatsthe-difference/.

Steenburgh \& Avery. 2010. Marketing analysis toolkit situation analysis. [referenced 23 October 2013] Available at: :

http://hbr.org/product/marketing-analysis-toolkit-situation-analysis/an/510079-PDFENG.

Service marketing mix.2012. [referenced 23 October 2013]. Available at:

http://www.marketing91.com/service-marketing-mix/.

Shodhganga. 2009. Marketing strategies of the banking industry. [referenced 16 October 2013]. Available at: :

http://shodhganga.inflibnet.ac.in/jspui/bitstream/10603/562/10/10_chapter\%202.pdf.

Singh. 2012. Factors affect bank performance. [referenced 13 October 2013].

Available at: :

http://vi.scribd.com/doc/49197222/FACTORS-AFFECTING-BANK-S-

PERFORMANCE.

Socio- economic statistics 2011. 2011. [referenced 23 October 2013]. Available at: : http://www.gso.gov.vn/default_en.aspx?tabid=508\&ItemID=11150.

SWOT - internal and external analysis. 2013. [referenced 6 October 2013]. .Available at:

http://guides.ucf.edu/content.php?pid=150566\&sid=1592753.

SWOT-analyse til besvar. 2011. [referenced 23 October 2013]. Available at: http://sven-reiselivstrategi.blogspot.fi/2011/02/swot-analyse-til-besvr.html. 
The-five-competitive-forces-that-shape-strategy. 2008. [referenced 13 October 2013]. Available at: :

http://hbr.org/2008/01/the-five-competitive-forces-that-shape-strategy/ar/1.

Task and function of the marketing department of the bank. 2012. [referenced 23 October 2013]. Available at:

http://www.bankbests.com/2012/12/tasks-and-functions-of-marketing.html.

The Maiden voyage of financial capitalism. 2009. [referenced 23 October 2013] Available at:

http://ageofvolatility.com/category/sources-of-volatili

The role of marketing in banking industry. 2012. [referenced 23 October 2013]. Available at:

http://www.thefinancialexpressbd.com/index.php?ref=MjBfMTBfMTJfMTJfMV85M18xNDY1NTI=. US framework and VALS types. 2009. [referenced 23 October 2013] Available at: http://www.strategicbusinessinsights.com/vals/ustypes.shtml.

What is marketing. 2011. [referenced 23 October 2013]. Available at: http://toolkit.smallbiz.nsw.gov.au/part/1/1/3.

Wykes. 2010. Bank pricing strategy. [referenced 23 October 2013]. Available at: http://www.slideshare.net/cwykes/bank-pricing-strategy-03-2013-17319637.

Zeiger. 2009. Markeeting strategies promoting bank. [referenced 23 October 2013]. Available at:

http://smallbusiness.chron.com/marketing-strategies-promoting-banks-21797.html. 


\section{Interviews}

Cuong,V. 2013. Managing director. Boomerang company. Interview 17 December 2012

Phong, N. 2013. Head department. Sacombank's Bahom transaction office. Interview 12June 2013

Sacombank staff. 2013. Sacombank. Interview 23 June 2013 


\section{APPENDICES}

APPENDIX 1. Sacombank's historic milestone (Sacombank 2012)

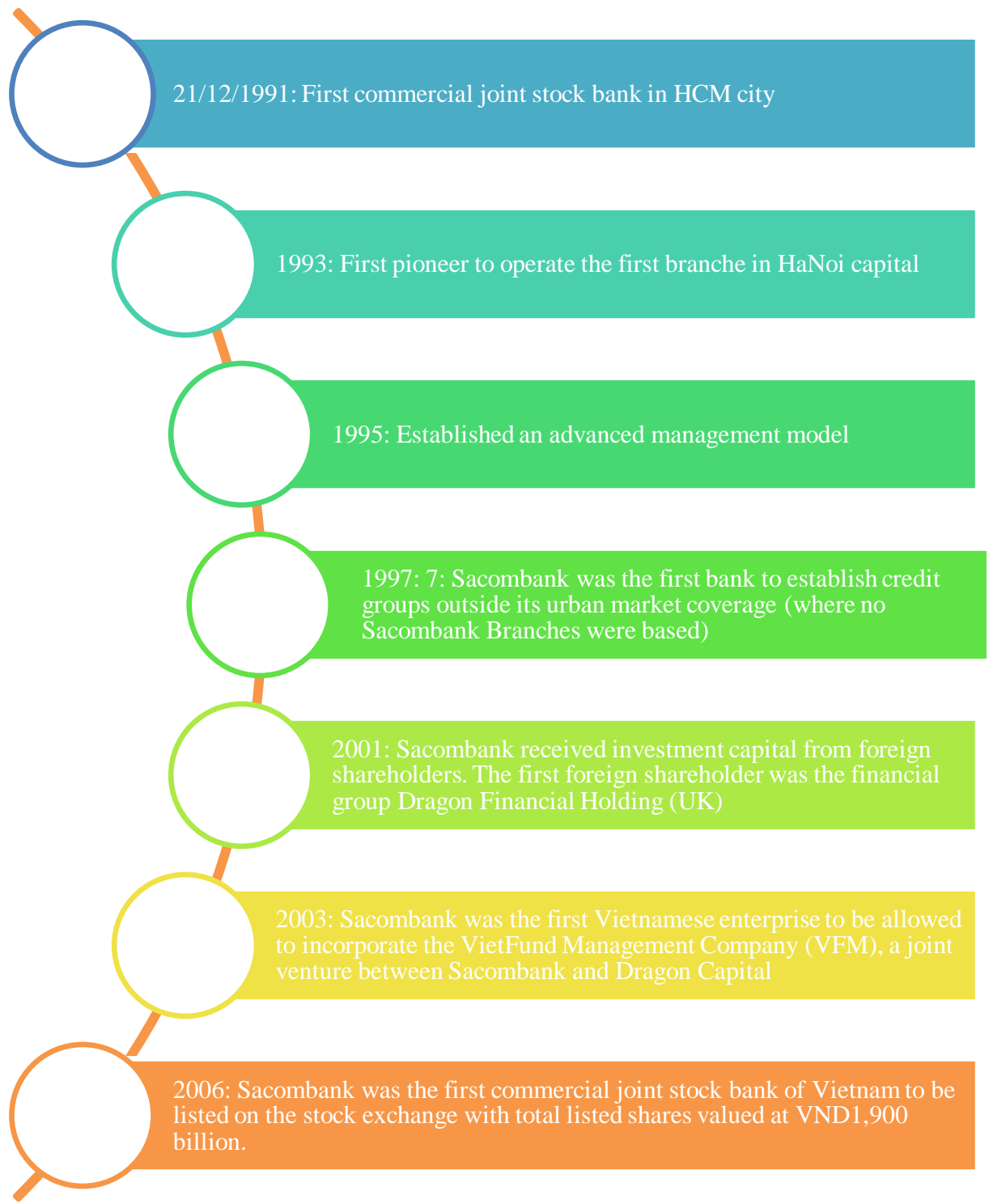




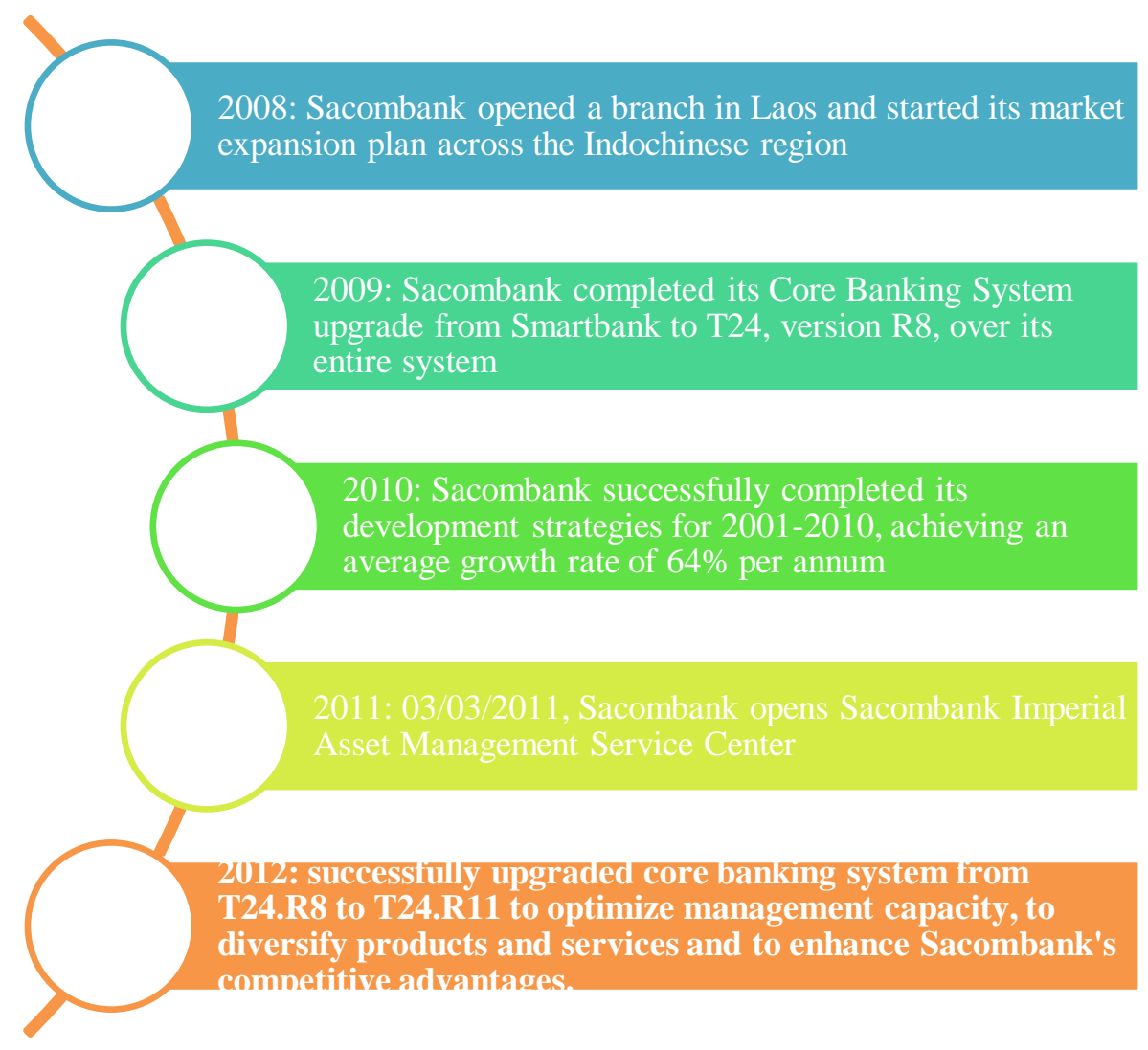

APPENDIX 2. Sacombank products and services (Sacombank 2013)

\begin{tabular}{|l|l|}
\hline Regular banking products & $\begin{array}{l}\text { - Current account } \\
\text { - Cards } \\
\text { - Saving accounts } \\
\text { - Loans }\end{array}$ \\
\hline Investment & - Portfolio management \\
& - Structured deposits \\
& - Investment portfolio services \\
& - Stocks \\
& \\
\hline Insurance & - Ferivatives \\
\hline Other banking service & - Critical illness insurance \\
\hline & - Phone banking \\
\hline
\end{tabular}


APPENDIX 6. Contact list

Sacombank group

Mr. Phan Nam

Managing Director

Address: 266 - 268 Nam Ky Khoi Nghia,

Ward 8, District 3, HCMC

Phone: (+84) 839320420

Fax: (+84) 839320424

Email: namphan@sacombank.com

Boomerang-vn Ltd

Mr Cuong Vong

Address:Thien Son building, 5th floor, 5 Nguyen Gia Thieu, District 3, Ho Chi Minh City, Vietnam

Phone: + 84-91-372-3988

Website: www. Boomerang-vn.com

Email: info@boomerang-vn.com 
Sacombank's bahom transaction office :

Mr. Nguyen Dinh Phong

Head of Transaction office

Address: Sacombank-Binh Tay branch- Ba Hom transaction office

Email: phongnd6552@sacombank.com

Nguyen Minh Tam

Sacombank's Laos branch

Office: 044 Haengboun Road, Haisok Villager, Chanthabury District, Vientiane Capital, Lao PDR.

Tel: (+856-21) 265725

Fax: $(+856-21) 265726$

Website: www.sacombank.com.la 
